\title{
LEVANTAMENTO, REPRODUÇÃO E PATOGENICIDADE DE NEMATÓIDES A FRUTEIRAS \\ DE CLIMA SUBTROPICAL E TEMPERADO
}

Carlos Eduardo Rossi

Tese apresentada à Escola Superior de Agricultura

"Luiz de Queiroz", Universidade de São Paulo, para obtenção do título de Doutor em Ciências, Área de Concentração: Entomologia.

P I R A C I C A B A

Estado de São Paulo - Brasil

Janeiro - 2002 


\section{LEVANTAMENTO, REPRODUÇÃO E PATOGENICIDADE DE NEMATÓIDES A FRUTEIRAS DE CLIMA SUBTROPICAL E TEMPERADO}

\section{CARlos Eduardo Rossi}

Engenheiro Agrônomo

Orientador: Prof. Dr. LUIZ CARLOS C. B. FERRAZ

Tese apresentada à Escola Superior de Agricultura "Luiz de Queiroz", Universidade de São Paulo, para obtenção do título de Doutor em Ciências, Área de Concentração: Entomologia.

P I R A C I C A B A

Estado de São Paulo - Brasil

Janeiro - 2002 
Dados Internacionais de Catalogação na Publicação (CIP)

DIVISÃO DE BIBLIOTECA E DOCUMENTAÇÃO - ESALQ/USP

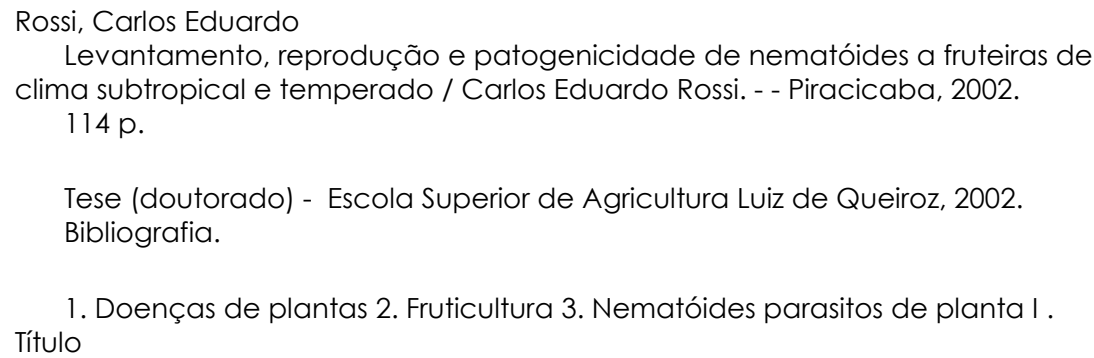

CDD 634

\section{"Permitida a cópia total ou parcial deste documento, desde que citada a fonte - $O$ autor"}


À minha querida filha Luísa,

DEDICO

À minha mãe, pai (in memorian), tia, irmãos, cunhados e sobrinha 


\section{AGRADECIMENTOS}

Deixar registrado aqui as pessoas e instituições que compartilharam comigo de seu planejamento, elaboração e, principalmente, de sua conclusão é uma tarefa mais do que justa. A paciência, compreensão com largos limites e confiança emprestados à minha pessoa pelo meu orientador Prof. Dr. Luiz Carlos Camargo Barbosa Ferraz, fazem dele um amigo e demonstra cada vez mais sabedoria e maturidade na arte de orientar. Contei com um apoio financeiro do $\mathrm{CNPq}$, que me permitiu estudar e me aperfeiçoar com maior tranqüilidade. A dedicação e o interesse da parte dos professores em ensinar e as facilidades oferecidas fazem do Curso de Pós-Graduação em Entomologia da ESALQ algo nobre, do qual tive a honra de ter participado. Um sonho realizado! Sem a compreensão de meus diretores do Instituto Biológico: Dra. Vera Cecília Annes Ferreira, Dr. Antonio Batista Filho e Dra. Zuleide Alves Ramiro teria sido impossível realizar tal obra. Uma tese não é feita por uma única pessoa, mas engloba uma rede de inestimáveis colaboradores, que prefiro nomear coletivamente como "amigos": Aloyséia Noronha, André, Arlindo Neto, César Bauer, Emmanuel, Família Kagi, Fernando Dall'Orto, Fernando Picarelli, Frederico Denardi, Gabriel Leite, Issao Ishimura, Ivan Antunes, Joaquim Avelino, Jorge Pinochet, José Fachinello, Leopoldo Nóbile, Luiz Ambrósio, Luiz Antunes, Nelson Pitta, Noeli Ferla, Paulo César, Pollyanna Montaldi, Takanoli Tokunaga, Wilson Barbosa, aos técnicos das casas de agricultura que forneceram localizações para coleta e a todos os fruticultores que permitiram a retirada de amostras em suas propriedades. Um injusto esquecimento pode ser creditado a um lapso.

Genótipos de fruteiras deveriam constar em museus, haja vista a escassez de fontes de materiais propagativos. $\mathrm{Na}$ verdade, não fosse a colaboração das instituições citadas na seqüência e de seus responsáveis, que me disponibilizaram tão valioso material, muito provavelmente o tema desta tese se referisse a outras espécies botânicas: Agromilhora Taperão, EPAGRI (Caçador), EPAMIG (Caldas, MG), Estações Experimentais de Jundiaí, Monte Alegre do Sul, Tiête e Centro de Fruticultura (IAC), Fruticultura Cristal, Núcleos de Produção de Mudas da CATI em São Bento do Sapucaí e Itaberá e Sítio Natal.

Creditar a um cientista a sua descoberta é o mínimo dentro da ética. E para referenciá-los corretamente tive o apoio das bibliotecárias Eliana M. Garcia e Kátia M. de A. Ferraz.

E finalmente deixo registrados os meus mais sinceros agradecimentos àquelas pessoas que não entenderam tudo o que está escrito aqui, mas que nunca me deixaram só nessa empreitada: meus familiares ! 


\section{SUMÁRIO}

LISTA DE FIGURAS............................................................................. Pánin

LISTA DE TABELAS ............................................................................

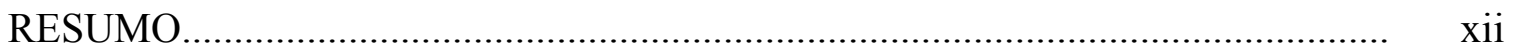

SUMMARY .......................................................................................

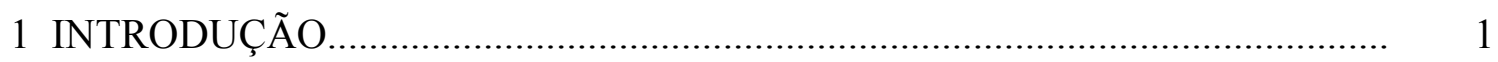

2 REVISÃO DE LITERATURA................................................................... 4

2.1 Nematóides em fruteiras de clima subtropical e temperado.............................. 4

2.1.1 Nematóides em amoreira-preta e framboeseira........................................ 4

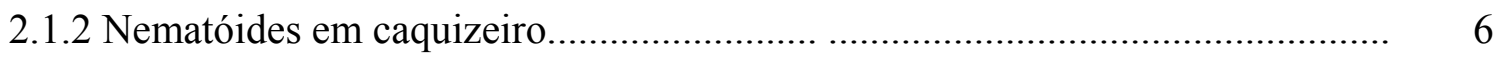

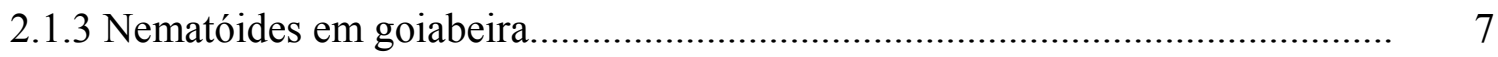

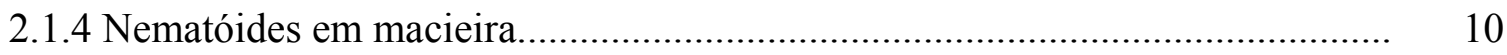

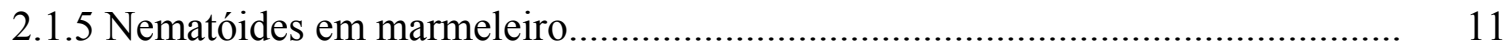

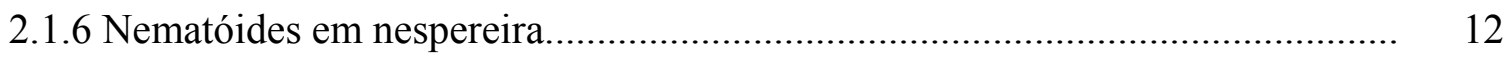

2.1.7 Nematóides em nogueira-macadâmia...................................................... 13

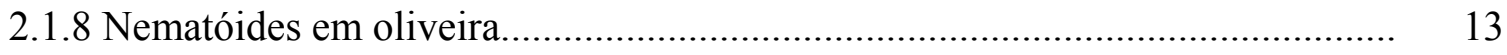

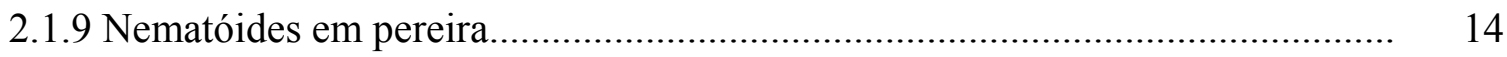

2.1.10 Nematóides em Prunus (pessegueiro, nectarineira, ameixeira e umezeiro)..... 15 
2.2 Reação de fruteiras ao parasitismo por nematóides.............................................. 19

2.2.1 Amoreira-preta e framboeseira............................................................... 20

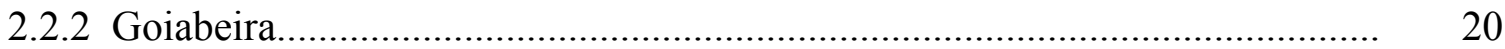

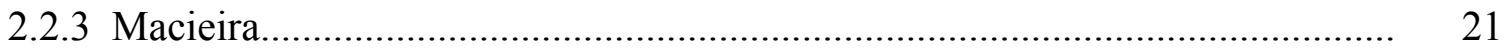

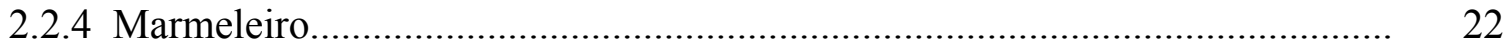

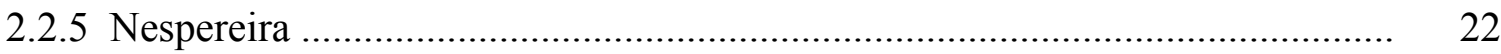

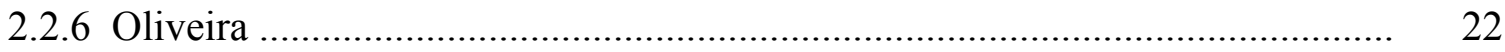

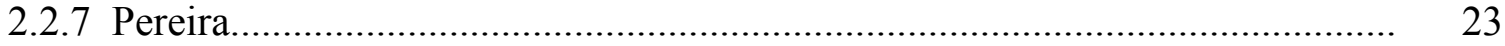

2.2.8 Pessegueiro e outros Prunus ............................................................... 24

2.2.8.1 Resistência a Meloidogyne spp.................................................................. 24

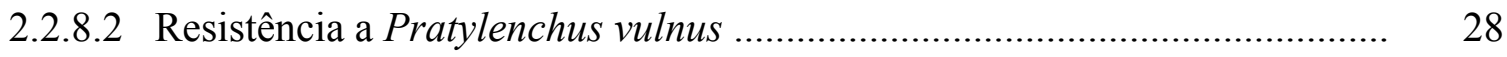

2.2.8.3 Resistência a Mesocriconema xenoplax............................................... 28

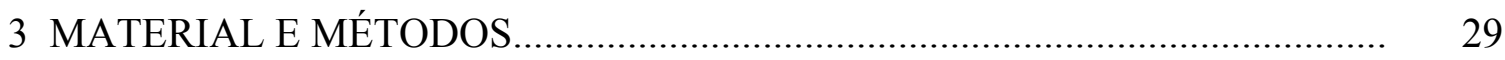

3.1 Levantamento de Nematóides Parasitos de Fruteiras...................................... 29

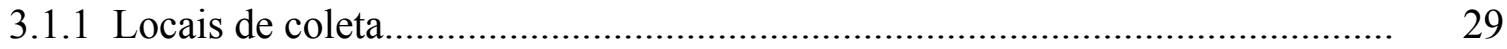

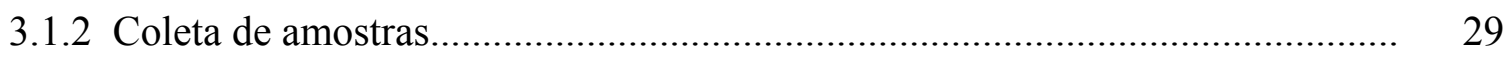

3.1.3 Extração e fixação dos nematóides............................................................. 33

3.1.4 Determinação da densidade populacional e identificação .............................. 33

3.1.5 Bio-ensaios e determinação da raça de Meloidogyne...................................... 34

3.2 Determinação da capacidade reprodutiva de nematóides de galhas em diferentes fruteiras.......................................................................... 34

3.2.1 Origem e formação das plantas.............................................................. 35

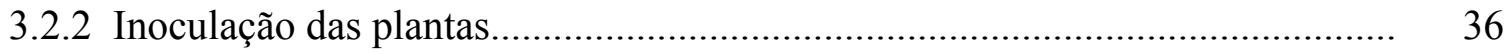


3.2.3 Delineamento estatístico e condução do experimento..................................... 36

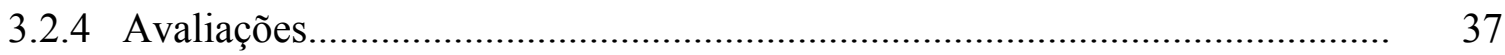

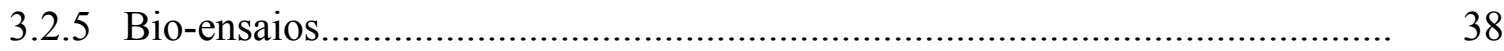

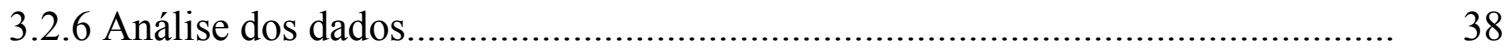

3.3 Determinação da capacidade reprodutiva de nematóides de galhas em

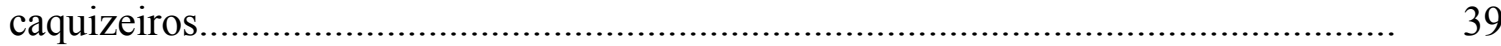

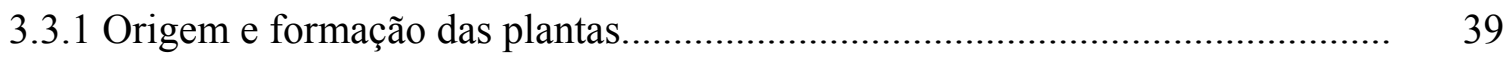

3.4 Patogenicidade de Meloidogyne incognita ao caquizeiro........................... 40

3.4.1 Origem e formação das plantas............................................................ 40

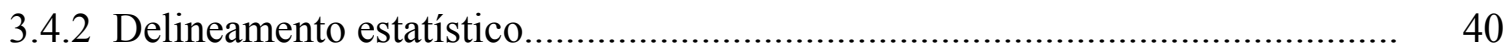

3.4.3 Inoculação das plantas e avaliação ................................................................ 40

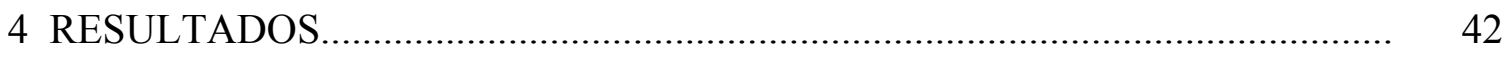

4.1 Levantamento de espécies..................................................................... 42

Família Criconematidae............................................................................ 42

Família Heteroderidae........................................................................... 52

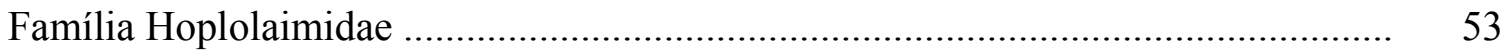

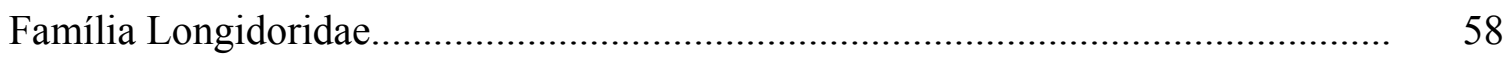

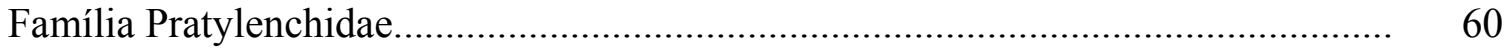

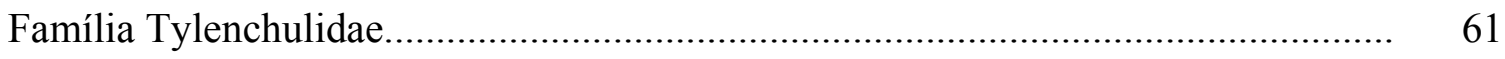

4.2 Capacidade reprodutiva dos nematóides de galhas nas fruteiras.......................... 61

4.3 Reação de caquizeiros aos nematóides de galhas.......................................... 62

4.4 Patogenicidade de Meloidogyne incognita ao caquizeiro................................... 65

5 DISCUSSÃO 
5.1 Levantamento de Nematóides........................................................................ 71

Família Criconematidae..................................................................................

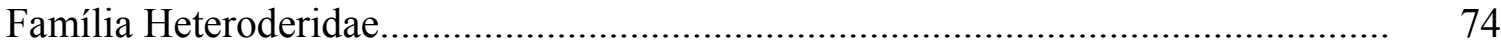

Família Hoplolaimidae .................................................................................. 76

Família Longidoridae ................................................................................ 78

Família Pratylenchidae.................................................................................... $\quad 79$

Família Tylenchulidae.................................................................................... 80

5.2 Capacidade reprodutiva dos nematóides de galhas nas fruteiras.......................... 80

5.3 Capacidade reprodutiva de Meloidogyne em caquizeiros..................................... 83

5.4 Patogenicidade de Meloidogyne incognita ao caquizeiro..................................... 84

5.5 Considerações Finais.................................................................................. 86

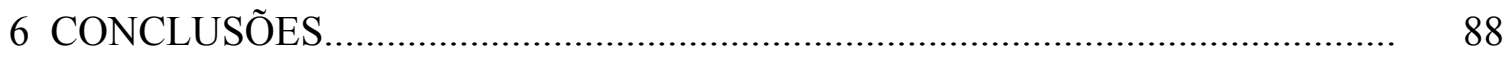

REFERÊNCIAS BIBLIOGRÁFICAS.............................................................. 89 


\section{LISTA DE FIGURAS}

Página

1 Municípios onde coletaram-se amostras para o estudo

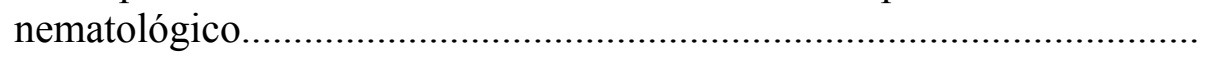

2 Distribuição dos dados de diâmetro de caquizeiros 'Kyoto' em relação ao nível populacional de Meloidogyne incognita raça $2 .$.

68

3 Distribuição dos dados de altura de caquizeiros 'Kyoto' em relação ao nível populacional de Meloidogyne incognita raça 2

4 Distribuição dos dados de massa seca de parte aérea de caquizeiros 'Kyoto' em relação ao nível populacional de Meloidogyne incognita raça 2 .

5 Distribuição dos dados de massa seca de raízes de caquizeiros 'Kyoto' em relação ao nível populacional de Meloidogyne incognita raça 2

6 Efeito de Meloidogyne incognita raça 2 sobre a altura de caquizeiros 'Kyoto'.

7 Efeito de Meloidogyne incognita raça 2 sobre a massa seca de raízes de caquizeiros 'Kyoto'. 


\section{LISTA DE TABELAS}

Página

1 Locais de coleta com respectivos municípios e propriedades e tipos de fruteiras amostradas durante o levantamento nematológico desenvolvido.

2 Caracteres morfométricos utilizados na identificação dos nematóides obtidos durante o levantamento e respectivas siglas.

3 Espécies botânicas, cultivares e origens dos materiais propagativos estudados.

4 Densidade populacional de nematóides de amostras de solo e raízes de fruteiras de clima subtropical e temperado.

5 Fitonematóides identificados durante o levantamento com respectivas porcentagens de ocorrência e posição relativa ("ranking") entre os gêneros e espécies.

6 Valores morfométricos de fêmeas de Mesocriconema xenoplax obtidos a partir de espécimes coletados em fruteiras de clima subtropical e temperado.

7 Valores morfométricos de fêmeas de Criconematidae encontradas associadas a fruteiras de clima subtropical e temperado durante o levantamento.

8 Espécies e raças de nematóides de galhas, Meloidogyne detectadas em fruteiras no Estado de São Paulo.

9 Valores morfométricos de fêmeas de Helicotylenchus dihystera obtidos a partir de espécimes coletados em fruteiras de clima subtropical e temperado. 
10 Valores morfométricos de fêmeas e machos de Hoplolaimidae obtidos a partir de espécimes coletados em fruteiras de clima subtropical e temperado.

11 Valores morfométricos de fêmeas de Xiphinema obtidos a partir de mensuração feita em espécimes coletados em fruteiras de clima subtropical e temperado.

12 Índice de galhas (IG) e de massas de ovos (IMO), número de nematóides no sistema radicular (NSR) e por grama de raiz (NGR) e reação (R) de Meloidogyne incognita raça 2 em fruteiras de clima subtropical e temperado aos 120 dias após a inoculação de 5.000 ovos por planta em 0,5 litros de solo.

13 Índice de galhas (IG) e de massas de ovos (IMO), número de nematóides no sistema radicular (NSR) e por grama de raiz (NGR) e reação (R) de Meloidogyne javanica em fruteiras de clima subtropical e temperado aos 120 dias após a inoculação de 5.000 ovos por planta em 0,5 litros de solo.

14 Médias de notas de infestação (NI), número de nematóides no sistema radicular (NSR) e por grama de raiz (NGR) de Meloidogyne incognita raça 2 em genótipos de caquizeiro aos 120 dias após a inoculação de 5000 ovos por planta

15 Médias de notas de infestação (NI), número de nematóides no sistema radicular (NSR) e por grama de raiz (NGR) de Meloidogyne javanica em genótipos de caquizeiros aos 120 dias após a inoculação de 5000 ovos por planta (dados de NSR e NGR transformados em $\log \mathrm{x}+1$ para a análise)

16 Efeito de níveis populacionais iniciais crescentes de Meloidogyne incognita sobre a altura, o diâmetro do caule e as massas secas da parte aérea (MSPA) e de raízes (MSR) do caquizeiro 'Kyoto'. 


\title{
LEVANTAMENTO, REPRODUÇÃO E PATOGENICIDADE DE NEMATÓIDES A FRUTEIRAS DE CLIMA SUBTROPICAL E TEMPERADO
}

\author{
Autor: Carlos Eduardo Rossi \\ Orientador: Prof. Dr. Luiz Carlos C.B. Ferraz
}

\section{RESUMO}

Objetivando melhor conhecimento a respeito dos nematóides encontrados associados a fruteiras de clima subtropical e temperado, coletaram-se 149 amostras de solo da rizosfera e de raízes de amoreira-preta, caquizeiro, framboeseira, macieira, marmeleiro, nespereira, nogueira-macadâmia, oliveira, pereira, pessegueiro e umezeiro em áreas de produção do Estado de São Paulo e em uma localidade de Minas Gerais. Como resultado desse levantamento, identificaram-se 11 gêneros e as espécies relacionadas a seguir: Aorolaimus nigeriensis, Discocriconemella degrissei, Helicotylenchus dihystera, H. erythrinae, H. microcephalus, H. pseudorobustus, Helicotylenchus spp., Hemicycliophora poranga, Meloidogyne hapla, M. incognita, M. javanica, Mesocriconema onoense, M. ornata, M. sphaerocephalum, M. xenoplax, Mesocriconema spp., Pratylenchus brachyurus, P. zeae, Rotylenchulus reniformis, Scutellonema brachyurus, Tylenchulus semipenetrans, Xiphinema brevicollum, $X$. elongatum, $X$. krugi, $X$. setariae, $X$. surinamense e Xiphinema spp.. Os três gêneros mais freqüentes foram Helicotylenchus, Mesocriconema e Xiphinema, presentes em 60,4; 55,0 e 30,2 \% das amostras, respectivamente; as espécies mais comuns foram H. dihystera e 
M. xenoplax, ocorrendo em 49 e 38,3\% das amostras. Contudo, apenas M. incognita e M. javanica estavam associados a danos em pessegueiros cujos porta-enxertos não tinham resistência genética. Em casa de vegetação, avaliaram-se as reações de genótipos das citadas fruteiras, mais goiabeira, frente aos nematóides de galhas Meloidogyne incognita raça 2 e M. javanica. As plantas, individualmente inoculadas com 5000 ovos de cada espécie de nematóide, foram conduzidas em recipientes plásticos durante 120 dias. A caracterização das reações baseou-se na capacidade reprodutiva dos parasitos, determinando-se os índices de massas de ovos e de galhas, bem como os números de nematóides por sistema radicular e por grama de raízes. Apenas a cultivar GF-677 de Prunus persica x $P$. dulcis comportou-se como suscetível, possibilitando desenvolvimento e multiplicação dos dois nematóides. Os demais genótipos avaliados foram hospedeiros desfavoráveis ao desenvolvimento dos nematóides, sendo considerados resistentes, embora vários deles tivessem proporcionado restritas taxas de reprodução dos parasitos. Estudou-se ainda, também sob condição de casa de vegetação, a patogenicidade de $M$. incognita raça 2 em caquizeiro 'Kyoto', verificando-se correlação negativa entre os níveis populacionais iniciais utilizados $(0,160,800,4000$, 20000 e 100000 ovos por parcela) e a altura e a massa seca de raízes das plantas, após seis meses da inoculação. Tendo em vista que a intensa formação de galhas radiculares observada e o efeito negativo sobre os dois parâmetros de crescimento das plantas mostraram-se associados a taxas de reprodução muito baixas do parasito, considerou-se que a reação ocorrida foi de intolerância. 


\title{
FIELD SURVEY, REPRODUCTION AND PATHOGENICITY OF NEMATODES TO SUBTROPICAL AND TEMPERATE FRUITS
}

\author{
Author: Carlos Eduardo Rossi \\ Adviser: Prof. Dr. Luiz Carlos C. B. Ferraz
}

\section{SUMMARY}

In order to achieve a better knowledge on the nematodes found associated with subtropical and temperate fruits, a total amount of 149 soil and root samples were collected from within apple, blackberry, japanese apricot, loquat, macadamia, olive, peach, pear, persimmon, quince and raspberry orchards located in the states of São Paulo and Minas Gerais, Southeastern Brazil. From this survey, a number of species belonging to eleven genera were identified, namely Aorolaimus nigeriensis, Discocriconemella degrissei, Helicotylenchus dihystera, $H$. erythrinae, H. microcephalus, H. pseudorobustus, Helicotylenchus spp., Hemicycliophora poranga, Meloidogyne hapla, M. incognita, M. javanica, Mesocriconema onoense, M. ornata, M. sphaerocephalum, M. xenoplax, Mesocriconema spp., Pratylenchus brachyurus, P. zeae, Rotylenchulus reniformis, Scutellonema brachyurus, Tylenchulus semipenetrans, Xiphinema brevicollum, $X$. elongatum, X. krugi, X. setariae, X. surinamense and Xiphinema spp. The most frequent genera were Helicotylenchus, Mesocriconema and Xiphinema, which occurred in 60.4, 
54.4 and $30.2 \%$ of the samples, respectively; the two most common species found were Helicotylenchus dihystera and Mesocriconema xenoplax, detected in 49.0 and $38.8 \%$ of the samples, respectively. However, only Meloidogyne incognita and M. javanica could be associated with peach trees that were stunted or showed general symptoms of decline; in these cases, the rootstocks did not have genetic resistance to root-knot nematodes. The host suitability of several genotypes of the mentioned fruit species, plus guava, were evaluated in relation to Meloidogyne incognita race 2 and M. javanica under greenhouse conditions. The plants were individually inoculated with 5,000 nematode eggs and kept to grow in plastic bags for four months. Nematode reproductive rate was determined with basis on gall index, egg mass index and numbers of nematodes per root system and per gram of roots. Only the cultivar GF-677 of Prunus persica x P. dulcis was susceptible to both nematode species. All other genotypes were poor/resistant hosts, even that some allowed the parasites to reproduce at low rates. The pathogenicity of Meloidogyne incognita race 2 to persimmon cv. Kyoto was also studied under greenhouse conditions. After six months of the inoculation with increasing nematode population levels - 0;160;800;4,000;20,000; and 100,000 eggs/plant - a negative correlation with plant height and top dry weight values was obtained. As an intense root galling was associated with low nematode reproductive rates and some depressive effects on the plant growth, the reaction was rated as being of intolerance. 


\section{INTRODUÇÃO}

A diversidade edafo-climática no Brasil condiciona agroecossistemas favoráveis ao cultivo de frutas. Apesar disso, o país não tem tradição na exportação e ainda importa diversos produtos, contrastando com o fato de estar na liderança da produção mundial (Fachinello et al., 1996). Nas últimas décadas, houve considerável expansão no cultivo de fruteiras de clima subtropical e principalmente temperado no país, apoiada por programas de melhoramento vegetal que, entre outros objetivos, visavam a obtenção ou adaptação de genótipos pouco exigentes em frio, já que esse é um requisito essencial à fisiologia dessas plantas (Ojima et al., 1984).

Ao nível mundial, tem-se verificado significativa evolução nos sistemas de produção, seja mediante utilização de alta densidade de plantas por unidade de área, para aumentar a produtividade, seja pelo manejo do ecossistema formado no pomar, para evitar competição com plantas invasoras. Da mesma maneira, a pesquisa com portaenxertos também tem avançado, estando dezenas de genótipos, com diferentes características, disponíveis aos fruticultores (Barbosa et al., 1997; Dall'Orto et al., 1992; Torrallardona, 1993).

$\mathrm{Na}$ fruticultura moderna, é comum a utilização de enxertia, que vem a ser a união de duas plantas em processo de simbiose: o porta-enxerto, responsável pelo sistema radicular, e o enxerto, que formará a copa da cultivar a ser explorada comercialmente. As interações entre ambas as partes fornecem diferentes resultados. Características usualmente exigidas de um porta-enxerto são: compatibilidade com a copa; plasticidade edáfica; resistência ao frio; longevidade; condicionante de vigor ou nanismo à planta (Nogueira, 1985). Por se tratarem de plantas perenes com cultivo intensivo e alto 
investimento a longo prazo, além dessas características, a resistência a problemas bióticos do solo é extremamente relevante.

Infelizmente, os pessegueiros, as nectarineiras e as ameixeiras cultivadas no Estado de São Paulo e em outros Estados brasileiros podem ser tidos como monoculturas quando se considera o porta-enxerto, já que há predomínio de apenas um único portaenxerto, o pessegueiro 'Okinawa', originário das ilhas Ryuku, em Okinawa, Japão. Com a informação de se tratar de genótipo resistente aos nematóides de galhas (do gênero Meloidogyne Goeldi, 1892), compatível com quase todas as cultivares de copa e pouco exigente em frio, esse porta-enxerto foi se difundindo e é atualmente o mais utilizado pelos viveiristas e produtores (Barbosa et al., 1993). Num enfoque mundial, atualmente, essa cultivar não tem sido mais utilizada diretamente como porta-enxerto, destinando-se, somente, como fonte de resistência a nematóides para cruzamentos interespecíficos (Torrallardona, 1993).

As perdas causadas por nematóides em fruteiras, principalmente na persicultura, são bastante conhecidas e estão bem documentadas na literatura (Gomes, 2001). E a essas perdas deve acrescentar-se ainda o custo da aplicação de nematicidas e o impacto desfavorável decorrente da presença desses produtos químicos no ambiente. Por isso, o item 'nematóides' é considerado indispensável quando se estuda o melhoramento de porta-enxertos para fruteiras de caroço (Pinochet, 1997).

As interações com algumas espécies de fitonematóides têm sido relativamente bem estudadas, como com Meloidogyne incognita (Kofoid \& White,1919) Chitwood, 1949 e M. javanica (Treub, 1885) Chitwood, 1949, que representam as duas principais espécies daninhas à fruticultura mundial (Nyczepir, 1991; Gomes, 2001). Porém, muito pouco se conhece sobre possíveis associações com outras espécies.

Como um primeiro objetivo deste trabalho pretendeu-se, portanto, conhecer um pouco melhor a diversidade da nematofauna corrente na rizosfera e nas raízes de diferentes fruteiras de clima temperado e subtropical cultivadas no Estado de São Paulo.

Do ponto de vista do controle, por se tratarem de culturas perenes, o combate aos nematóides fica restrito a alguns métodos e, dentre eles, o controle varietal, empregando a resistência genética, é o mais estudado e promissor (Nyczepir \& Halbrendt, 1993). 
Nesse aspecto, são raros os estudos referentes à macieira, pereira, oliveira, goiabeira, amoreira-preta e framboeseira e, nos casos de umezeiro (porta-enxerto ananicante para pessegueiro), nespereira e nogueira-macadâmia, praticamente inexistem trabalhos a respeito (Cohn \& Duncan, 1990; McSorley, 1992). Tendo em vista a evidente carência de maior conhecimento a respeito da relação entre os nematóides do gênero Meloidogyne e fruteiras de clima subtropical e temperado e a recente estratégia de diversificação implementada em relação às cultivares de porta-enxertos utilizadas no Brasil, com a introdução de novos genótipos, afigura-se prudente caracterizá-los quanto à reação a esses importantes nematóides. Portanto, com base no exposto e numa segunda fase do trabalho desenvolvido, objetivou-se estudar a reação (resistência/suscetibilidade) de genótipos de onze fruteiras de interesse econômico frente a Meloidogyne incognita raça 2 e $M$. javanica sob condições controladas. Ainda dentro dessa etapa, procurou-se, de modo adicional, aferir a ação patogênica de Meloidogyne incognita raça 2 especificamente para o caquizeiro. 


\section{REVISÃO DE LITERATURA}

\subsection{Nematóides em fruteiras de clima subtropical e temperado}

\subsubsection{Nematóides em amoreira-preta e framboeseira}

Amoreiras-pretas e framboeseiras pertencem ao gênero Rubus, formando o grupo de plantas que, ao que tudo indica, apresenta a maior diversidade dentro da família Rosaceae. A classificação das espécies é muito difícil, já que apresentam diferentes hábitos de crescimento e distribuição geográfica muito variada (Ellis et al., 1991). São usualmente propagadas por estacas de raízes ou de ramos herbáceos (Steinberg, 1989).

Relatos mais antigos a respeito de associações entre fitonematóides e espécies de Rubus em todo o mundo, referentes principalmente às décadas de 1940 e 1950, podem ser encontrados no clássico catálogo de Goodey et al. (1965). Tais assinalamentos referiam-se, com maior freqüência, a espécies dos gêneros Criconema, Meloidogyne, Paratylenchus, Pratylenchus e Xiphinema.

Esnard \& Zuckerman (1998) consideraram que, em âmbito mundial, os gêneros Criconema, Hemicycliophora, Longidorus, Meloidogyne, Mesocriconema (sinônimo de Criconemella), Pratylenchus e Xiphinema são os mais comumente encontrados associados a plantas do gênero Rubus. Dentre eles, Pratylenchus tem sido o mais freqüente em cultivos na América do Norte e Europa. Belair \& Khanizadeh (1994) já haviam verificado tal fato no Canadá, em levantamento realizado na região geoeconômica de Quebec, quando determinaram que 46,4 \% das áreas de cultivo de framboeseiras amostradas encontravam-se infestadas por Pratylenchus spp.. Pelo menos seis espécies desse gênero estão envolvidas com essas fruteiras, sendo Pratylenchus 
penetrans (Cobb, 1917) Chitwood \& Oteifa, 1952 a mais importante (McElroy, 1991). Redução no crescimento de plantas e sistema radicular com poucas raízes secundárias, parcial ou totalmente necrosadas, são comuns em framboeseiras atacadas (McElroy, 1972). A patogenicidade dessa espécie foi demonstrada por Trudgill (1983), que verificou correlação negativa entre a densidade populacional do parasito e o crescimento de framboeseiras.

Steinberg (1989) afirma que nematóides que incitam galhas radiculares, muito provavelmente referindo-se a Meloidogyne spp., prejudicam o desenvolvimento normal de amoreira-preta e framboeseira, diminuindo a brotação dos ramos. Segundo Griffin et al., (1968), Meloidogyne hapla Chitwood, 1949 tem sido a única espécie encontrada parasitando framboeseiras; entretanto, nas cultivares Canby e Newburgh, tal parasitismo tem aparentemente causado apenas um aumento na incidência da galha de coroa causada por Agrobacterium tumefaciens (Smith \& Townsend) Conn.

Duas espécies de Xiphinema têm sido encontradas associadas a Rubus spp.. No Canadá, Xiphinema bakeri Williams, 1961 tem causado consideráveis danos diretos mesmo em baixas populações (1 nematóide $/ 5 \mathrm{~cm}^{3}$ de solo), reduzindo em 40 a $50 \%$ o crescimento da parte aérea e raízes de framboeseiras. Seu local preferencial de parasitismo é a ponta das raízes, que, no geral, ficam engrossadas e tipicamente recurvadas (McElroy, 1972). Na Europa, Xiphinema diversicaudatum (Micoletzky, 1927) Thorne, 1939, além de causar danos diretos, pode atuar como importante vetor de nepoviroses às framboeseiras (Brown et al., 1993). Outros relatos de transmissão de nepoviroses a framboeseiras estão associados a espécies do gênero Longidorus, nos Estados Unidos e Europa (McElroy, 1972; 1991).

Três nematóides já foram relatados associados a Rubus spp. no Brasil, mais precisamente no Estado de São Paulo: Meloidogyne sp. (Carvalho, 1951), Pratylenchus vulnus Allen \& Jensen, 1951 e Helicotylenchus dihystera (Cobb, 1893) Sher, 1961 (Monteiro \& Lordello, 1976). Estes últimos autores observaram que as plantas infestadas exibiam mumificação da infrutescência. A propósito, declínio de framboeseiras também é um sintoma associado com Pratylenchus vulnus em Utah (EUA) (McElroy, 1972). 


\subsubsection{Nematóides em caquizeiro}

A propagação dessa fruteira é feita por enxertia e o porta-enxerto é o próprio caquizeiro oriundo de sementes de Diospyros kaki L.. Nos Estados Unidos, D. lotus L. e D. virginiana L. apresentam características agronômicas diferenciadas, o que os habilita como excelentes porta-enxertos para determinadas situações (Ojima et al., 1978).

Essa cultura foi pouco estudada com relação aos seus nematóides parasitos (Cohn \& Duncan, 1990). De acordo com esses autores, o caquizeiro é suscetível a Tylenchulus semipenetrans Cobb, 1913, não se conhecendo bem a reação a outros reconhecidos parasitos dessa fruteira, como Meloidogyne spp. e Radopholus similis (Cobb, 1893) Thorne, 1949.

González (1988) associou altos níveis populacionais de T. semipenetrans a plantas com crescimento reduzido, pouco produtivas e com sistema radicular pobre em raízes secundárias. Encontraram-se também altas populações desse parasito em solo e raízes dos porta-enxertos D. virginiana em Israel (Cohn \& Minz, 1961) e D. lotus na Califórnia, EUA (Nesbitt, 1956; Raski et al., 1956), e na Itália (Di Maio, 1979). Neste último relato, a estimativa de prejuízos na produção variou de 20 a $30 \%$.

McSorley et al. (1982) coletaram amostras na rizosfera de três outras espécies de Diospyros. Verificaram a presença de Mesocriconema sphaerocephalum (Taylor, 1936) Loof \& de Grisse, 1989, H. dihystera e Rotylenchulus reniformis Linford \& Oliveira, 1940 em D. discolor Willd. Em D. ebenaster Retz. e D. senegalensis (Perr.) A. DC., detectaram-se $R$. reniformis e Xiphinema americanum Cobb, 1913.

Sethi et al. (1988) identificaram Meloidogyne javanica (Treub, 1885) Chitwood, 1949 em raízes de mudas de caquizeiro (D. kaki) em viveiros na Índia.

$\mathrm{Na}$ literatura brasileira, Sharma (1973), ao realizar levantamento nematológico no Estado de Pernambuco, registrou a presença de Aphelenchoides sp. e H. dihystera em $D$. kaki. O mesmo autor (Sharma, 1977), amostrando fruteiras no Estado da Bahia, encontrou $R$. reniformis e Tylenchus spp. associados ao caquizeiro.

Meloidogyne incognita (Kofoid \& White, 1919) Chitwood, 1949 e $T$. semipenetrans foram relatados pela primeira vez parasitando caquizeiro no País em 1991 
(Inomoto et al., 1991). A ocorrência deu-se em raízes de plantas com cerca de 30 anos de idade, oriundas de Santo Anastácio (SP). Os autores não mencionaram os níveis populacionais observados, mas os sintomas nas raízes eram galhas alongadas e pouco evidentes, localizadas nas extremidades das raízes. Fêmeas maduras de T. semipenetrans apresentavam-se parcialmente penetradas nas raízes, recobertas por solo aderente, de modo similar ao que ocorre em Citrus.

Em estudo sobre a fauna nematológica do Rio Grande de Sul, Sperandio (1992) verificou a ocorrência de Cephalenchus leptus (Siddiqi, 1963) Knobloch, 1972, Psilenchus hilarulus De Man, 1921 e Tylenchorhynchus sp. em solo da rizosfera de caquizeiros.

\subsubsection{Nematóides em goiabeira}

A propagação dessa fruteira é feita por sementes ou por estaquia, com o uso de hormônios para o enraizamento (Kwee \& Chong, 1990).

A goiabeira é uma eficiente planta hospedeira para nematóides. Prova disso são as citações na literatura mundial da ocorrência de 72 espécies associadas a essa fruteira (McSorley, 1992).

Cohn \& Duncan (1990) consideraram Meloidogyne o principal gênero de nematóides daninhos às goiabeiras, conforme evidenciado pelo expressivo número de estudos a respeito. Nesse aspecto, Meloidogyne incognita tem sido referido comumente como o agente causal do tamanho reduzido de frutos e do crescimento lento de goiabeiras na Ásia e na América Central (Kwee \& Chong, 1990).

Gonzalvez (1989) realizou levantamento da nematofauna ocorrente em pomares de goiabeira de Cuba e encontrou 67 espécies pertencentes a 22 gêneros. Meloidogyne incognita, M. arenaria (Neal, 1889) Chitwood, 1949 e M. hapla relacionaram-se com galhas, rachaduras nas raízes e clorose foliar observadas nas plantas, ocorrendo em $96 \%$ das áreas amostradas. Detectaram-se também Pratylenchus brachyurus (Godfrey, 1929) Filipjev \& S. Stekhoven, 1941, P. neglectus (Rensch, 1924) Filipjev \& S. Stekhoven, 
1941, R. similis e $X$. americanum, além de espécies não identificadas pertencentes aos gêneros Longidorus, Mesocriconema, Helicotylenchus, Rotylenchulus e Trichodorus.

$\mathrm{Na}$ Venezuela, tem sido bem estudada a relação entre nematóides e goiabeiras. Petit (1990) verificou a presença de diversas espécies de Helicotylenchus, Meloidogyne, Paratylenchus, Tylenchorhynchus e Tylenchus em pomares de três estados produtores. Crozzoli et al. (1992) realizaram levantamento da nematofauna associada a goiabeiras no Estado de Zulia e verificaram que os principais nematóides ligados a problemas de mau desenvolvimento de plantas e quedas de produção foram Meloidogyne arenaria e $M$. incognita, presentes em 42,9\% das amostras de solo processadas; posteriormente, Crozzoli \& Casassa (1998) voltaram a enfatizar a importância dos nematóides de galhas como agentes causais do declínio de goiabeiras no país, destacando $M$. incognita raça 1 como a mais disseminada e daninha das formas de Meloidogyne. Casassa et al. (1998), também no Estado de Zulia, demonstraram a patogenicidade de $M$. incognita raça 1 à cultivar suscetível Criolla Roja de Psidium guajava L. e a resistência de Psidium friedrichsthalianum (Beng.) Nied.. Aliás, essa espécie de goiabeira já fora selecionada anteriormente como genótipo resistente a nematóides por Diaz-Silveira (1975); portanto, espécies como $R$. reniformis e $X$. americanum, encontradas associadas a plantas de $P$. friedrichsthalianum por McSorley et al. (1982), merecem ser melhor estudadas, já que essa espécie tem sido referida como porta-enxerto resistente para P. guajava. McSorley (1992) incluiu ainda Hoplolaimus indicus Sher, 1963 e H. dihystera como espécies comprovadamente patogênicas à goiabeira com base em estudos que envolveram inoculação artificial de plantas sob condições experimentais controladas.

Também na África, mais especificamente na Nigéria, Khan (1985) observou $M$. incognita freqüentemente associada a goiabeiras, ocorrendo em $33 \%$ das amostras coletadas na rizosfera das plantas amostradas.

Revisando a literatura, Cohn \& Duncan (1990) concluíram que os casos de danos severos causados por espécies de Meloidogyne em goiabeiras na América Central e África podem estar relacionados à existência de certas raças altamente virulentas e especializadas desses nematóides. 
No Brasil, Moura \& Moura (1989) constataram intenso ataque de M. incognita raça 2 em raízes de goiabeiras no Estado de Pernambuco com formação de volumosas e típicas galhas, além de decomposição do córtex, ocasionando a morte rápida da planta. Tais pomares foram formados em áreas que haviam antes sido ocupadas por canaviais e que comprovadamente sofreram sérias perdas devidas a nematóides de galhas. Moreira et al. (2001) afirmaram que M. incognita é o responsável pelos maiores danos relacionados com queda de produção e morte de goiabeiras em Pernambuco, principalmente com a cultivar Paluma. Ferreira Filho et al. (2000) caracterizaram uma espécie aparentemente nova de Meloidogyne ocorrendo em ataques recentes a goiabeiras nos Estados de São Paulo e Rio de Janeiro, causando sintomatologia similar à observada em Pernambuco, com alta incidência de plantas mortas.

Outros relatos brasileiros estabeleceram Aorolaimus holdemani (Sher, 1964) Fortuner, 1987 (sin. Peltamigratus holdemani), Basiria sp., Belonolaimus sp., Dolichodorus minor Loof \& Sharma, 1975, Helicotylenchus spp., Hemicycliophora spp., M. onoense (Luc, 1959) Loof \& de Grisse, 1989 (sin. C. onoensis), R. reniformis, Tylenchorhynchus phaseoli Sethi \& Swarup, 1968, Tylenchus spp. e Xiphinema setariae Luc, 1958 como parasitos ou habitantes do solo da rizosfera de goiabeiras na Bahia e Pernambuco (Sharma, 1973; 1977). Ferraz (1980) detectou Filenchus sp., H. dihystera, H. pteracercus Singh, 1971, Helicotylenchus sp., M. onoense, Mesocriconema sp., Meloidogyne sp., Nothocriconema sp., Pratylenchus sp., Psilenchus sp., Tylenchus sp. e Xiphinema setariae em solo de goiabeiras cultivadas em Minas Gerais. No Vale do Rio São Francisco, durante levantamento em pomares de frutíferas, Moreira et al. (2001) encontraram Aorolaimus spp., H. dihystera, Helicotylenchus sp., Hemicycliophora spp., Hoplolaimus spp., Meloidogyne spp., Pratylenchus spp., Tylenchorhynchus spp. e Xiphinema spp. associadas a goiabeiras.

\subsubsection{Nematóides em macieira}

$\mathrm{Na}$ propagação dessa fruteira, enxertam-se cultivares de copa em estacas enraizadas produzidas por amontoa-de-cepa de macieiras (Malus X domestica Borkh.) 
chamadas de porta-enxertos clonais, podendo também enxertá-las em plantas oriundas de sementes (Penteado, 1986).

McElroy (1972) e Wehunt (1984) citam que as espécies de nematóides mais importantes para essa fruteira são Pratylenchus penetrans, responsável pelo "cansaço do solo" de viveiros e pomares da Europa, bem como do declínio e problemas de replantio em pomares nos Estados Unidos; e P. vulnus, causador de danos nos Estados norteamericanos da Califórnia e Oregon. O termo "problemas de replantio" representa uma doença de etiologia complexa que ocorre em locais de substituição de pomares antigos por novos, envolvendo nematóides, fungos, bactérias e fatores abióticos (Dullahide et al., 1994; Pruyne et al., 1994). Philis (1995), em levantamento realizado na Ilha de Chipre, encontrou uma outra espécie de Pratylenchus parasitando macieiras, P. brachyurus, além de espécies não identificadas de Helicotylenchus e Tylenchorhynchus.

$\mathrm{Na}$ literatura, há trabalhos sobre a ocorrência de Meloidogyne spp. em pomares de macieira. Meloidogyne incognita tem sido encontrada na Índia (Khan \& Sharma, 1990) e M. arenaria, M. hapla, M. incognita e M. javanica em solo de pomares na Califórnia, EUA (Kodira \& Westerdahl, 1996). Entretanto, a única espécie confirmada como patogênica a Malus é Meloidogyne mali Itoh, Ohshima \& Ichinohe, 1969. É considerada muito importante para a cultura, pois reduz o crescimento das plantas em 15 a $43 \%$ no Japão (Itoh et al., 1969). Não há registros dessa espécie em solo brasileiro.

Tacconi \& Mancini (1990) relacionaram a ocorrência comum de nematóides dos gêneros Longidorus, Mesocriconema, Paratrichodorus, Paratylenchus, Trichodorus e Xiphinema associados a macieiras em áreas de produção ao redor do mundo, mas sem evidência experimental de importância econômica para a cultura. Sabe-se, contudo, que, independentemente dos danos diretos causados, espécies do chamado "grupo do Xiphinema americanum" podem transmitir nepoviroses altamente prejudiciais a macieiras nos Estados Unidos, sendo nesses casos responsáveis por elevadas perdas indiretas (Nyczepir \& Halbrendt, 1993).

A primeira referência no Brasil é a ocorrência de Pratylenchus sp. parasitando raízes de macieira oriundas de Valinhos, SP (Lordello \& Melo, 1958). No Estado de 
Minas Gerais, Ferraz (1980) detectou Aphelenchoides sp., Hemicycliophora oostenbrinki Luc, 1958 e M. onoense em solo de rizosfera de macieiras.

Em levantamento junto ao laminário da coleção nematológica da Universidade de Brasília, Café Filho \& Huang (1988) identificaram Pratylenchus jordanensis Hashim, 1983 e P. zeae Graham, 1951 associados a Malus sylvestris. Desse mesmo estudo resultou que uma nova espécie, $P$. pseudofallax Café Filho \& Huang, 1989, foi descrita a partir de população obtida de rizosfera de macieiras. Todas essas ocorrências são de localidades do Sul do Brasil, caracterizadas por climas amenos. Da mesma região, mais precisamente de Vacaria, RS, encontrou-se também a espécie Pratylenchus scribneri Steiner, 1943 e identificaram-se ainda Ditylenchus sp., H. dihystera, Meloidogyne sp., Mesocriconema sp. e Tylenchus sp. em amostras de mudas e plantas adultas de macieiras (Monteiro et al., 1987).

Becker (1991) realizou levantamento nematológico em pomares de macieiras em Fraiburgo e Caçador (SC) encontrando formas pertencentes aos gêneros Aphelenchoides, Discocriconemella, Helicotylenchus, Meloidogyne, Mesocriconema, Pratylenchus, Scutellonema, Trichodorus, Tylenchus e Xiphinema, sendo Tylenchus o mais freqüente e Helicotylenchus o de maior densidade populacional. O autor não incluiu maiores informações a respeito dos possíveis danos causados pelos nematóides nas áreas produtoras amostradas.

\subsubsection{Nematóides em marmeleiro}

O marmeleiro (Cydonia oblonga Mill.) foi uma cultura de importância ímpar na história do Brasil (Gonçalves, 1954). Entretanto, atualmente são raros os cultivos comerciais, sendo o sul de Minas uma das poucas regiões em que o seu cultivo ainda está estabelecido (Dall'Orto, 1982). Emprega-se essa fruteira como porta-enxerto ananicante para nespereiras e pereiras. Faz-se a sua propagação por meio de sementes ou estaquia (Rigitano et al., 1975a; Dall'Orto et al., 1990). 
Com relação aos nematóides fitoparasitos, há apenas o registro de Xiphinema surinamense Loof \& Maas, 1972 ocorrendo, naturalmente, em solo de marmeleiro no Estado de São Paulo (Zem, 1977).

\subsubsection{Nematóides em nespereira}

A nêspera apresenta uma característica economicamente favorável que é a maturação no período de escassez de frutas no mercado, ou seja, maio a outubro (Ojima et al., 1977). As cultivares de copa são enxertadas sobre nespereiras oriundas de sementes de cultivares comerciais ou também sobre o marmeleiro, o que lhe confere nanismo (Penteado, 1986).

Existem poucos estudos sobre nematóides em nespereiras (Cohn \& Duncan, 1990; McSorley, 1992), no geral restritos a simples menções de associações observadas em condições naturais de cultivo. Assim, McSorley (1992) refere-se genericamente à nespereira como hospedeira de $R$. similis e T. semipenetrans. Já Phyllis (1995) relata o parasitismo de nespereiras por nematóides de galhas do gênero Meloidogyne na Ilha de Chipre, sem identificar a(s) espécie(s) envolvida(s).

Inserra \& Vovlas (1980) estudaram a biologia de Rotylenchulus macrodoratus Dasgupta, Raski \& Sher, 1968 em três diferentes hospedeiros, sendo a nespereira um deles. Evidenciou-se a formação de sítio de alimentação, caracterizado por célula gigante única, mononucleada e hipertrofiada, ao nível da endoderme, a partir da qual o parasito obteve os nutrientes necessários ao completo desenvolvimento e à reprodução. A nespereira foi considerada boa hospedeira do nematóide, mas os possíveis efeitos de sua ação patogênica não foram avaliados.

No Brasil, Sharma (1973) detectou Pratylenchus sp., T. phaseoli, Tylenchus sp. e Xiphinema sp. na rizosfera de nespereiras em duas localidades do Vale do Rio São Francisco, em Pernambuco. Na região de Ilha Solteira (SP), Monteiro et al. (1978) relataram a ocorrência de X. krugi Lordello, 1955 e, em Minas Gerais, Ferraz (1980) determinou a ocorrência de Helicotylenchus sp., M. onoense, Pratylenchus sp., P. zeae e Xiphinema sp.. 


\subsubsection{Nematóides em nogueira-macadâmia}

A nogueira-macadâmia é enxertada em plantas da mesma espécie botânica oriundas de sementes (Ojima et al., 1984).

Apesar da grande expansão dessa cultura no mundo, raras informações são disponíveis sobre o parasitismo por nematóides (Cohn \& Duncan, 1990). Por exemplo, nos Estados Unidos, McSorley et al. (1982) encontraram as espécies $H$. dihystera, $M$. sphaerocephalum, $R$. reniformis e $X$. americanum associadas a raízes dessa fruteira. Por outro lado, a única citação na literatura nacional parece ser a de Ferraz (1980), que observou Helicotylenchus sp. e M. onoense na rizosfera de plantas amostradas durante levantamento nematológico conduzido em Minas Gerais.

\subsubsection{Nematóides em oliveira}

Hashim (1982) preparou revisão sobre os nematóides que atacam oliveiras, alistando mais de 70 espécies. Estas pertenciam a muitos gêneros sendo Helicotylenchus, Meloidogyne, Pratylenchus, Tylenchulus e Xiphinema os mais freqüentes. Meloidogyne incognita e M. javanica são consideradas as espécies mais importantes e daninhas.

Há apenas um relato na literatura nacional que trata do assunto, qual seja a ocorrência de M. javanica em oliveira no Rio Grande do Sul (Lordello \& Marini, 1974). 


\subsubsection{Nematóides em pereira}

Os porta-enxertos para pereiras utilizados normalmente são pereiras européias (Pyrus communis L.) e pereiras orientais (P. calleryana Decaisne e P. betulaefolia Bunge) ou marmeleiros (Cydonia oblonga Mill.) obtidos a partir de sementes (Rigitano et al., 1975a; Dall'Orto et al., 1996; Barbosa et al., 1997).

Existem muitas espécies de nematóides associadas a pereiras no mundo, porém umas poucas são tidas como patogênicas (Abawi \& Mai, 1990).

No Japão, há relatos de parasitismo por T. semipenetrans (Raski, 1991) e por nematóides de galhas, em especial M. incognita e M. hapla (Saigusa \& Matsumoto ${ }^{1}$ citados por Nyczepir \& Halbrendt, 1993). No entanto, Wehunt (1984) afirmou que os nematóides de galhas, Meloidogyne spp., não representam problema maior ao cultivo de pereiras nos Estados Unidos.

Swart \& Hugo (1984) realizaram levantamento das espécies que atacam pereiras na África do Sul e observaram a presença de Helicotylenchus spp., Meloidogyne sp., Paratrichodorus sp., Pratylenchus sp., Xiphinema sp., $X$. americanum e $X$. diversicaudatum. Abawi \& Mai (1990) acrescentaram Xiphinema rivesi Dalmasso, 1969 e $X$. vuittenezi Luc et al., 1964 à lista de nematóides de interesse para a fruteira na África, podendo causar, quando em grandes populações, crescimento lento e baixa produtividade. Dos nematóides citados, Tacconi \& Mancini (1990) consideraram as espécies de Meloidogyne, Pratylenchus e Xiphinema como possivelmente as mais importantes do ponto de vista econômico.

Pratylenchus coffeae (Zimmerman, 1898) Filipjev \& S. Stekhoven, 1941, P. crenatus Loof, 1960, P. neglectus, P. penetrans, P. thornei Sher \& Allen, 1953 e $P$. vulnus são parasitos de pereiras (McElroy, 1972), porém apenas P. penetrans está efetivamente associada ao fraco desenvolvimento de plântulas e problemas de replantio em pomares dos Estados Unidos (Townshend, 1990; Nyczepir \& Halbrendt, 1993).

\footnotetext{
${ }^{1}$ SAIGUSA, T.; MATSUMOTO, Y. A list of the host plants of the Meloidogyne incognita var. acrita and M. hapla. Plant Protection Service Japan Research Bulletin, v.1, p.84-88, 1961.
} 
No Brasil, Lordello \& Zamith (1960a) encontraram raízes de pereira infestadas por M. incognita (sin. M. incognita acrita) procedentes de Piracicaba (SP). Ferraz (1980), analisando amostras de solo de diferentes culturas no Estado de Minas Gerais, encontrou Aphelenchoides sp., Criconema mutabile (Taylor, 1936) Raski \& Luc, 1987, Filenchus sp., Helicotylenchus sp., H. dihystera, Hemicriconemoides sp., Meloidogyne sp., M. onoense, Pratylenchus sp., P. zeae, R. reniformis, Tylenchus sp. e Xiphinema sp. associadas a pereiras.

\subsubsection{Nematóides em Prunus (pessegueiro, nectarineira, ameixeira e umezeiro)}

Os pessegueiros [Prunus persica (L.) Batsch], nectarineiras [P. persica var. nucipersica (Ait.) Maxim.] e ameixeiras ( $P$. cerasifera Ehre. e $P$. domestica L.) são normalmente enxertados em pessegueiros ou ameixeiras oriundas de sementes (Penteado, 1986).

O pessegueiro e a ameixeira são considerados eficientes hospedeiros de muitas espécies de nematóides. As mais importantes economicamente pertencem aos gêneros Meloidogyne, Mesocriconema e Pratylenchus.

As espécies $M$. arenaria, $M$. incognita e $M$. javanica têm distribuição mundial e quase todas as cultivares de pessegueiro lhes são suscetíveis, sofrendo danos bastante sérios. Tamanho reduzido das árvores, baixo vigor, desfolha precoce e, por vezes, morte de plantas associada a sistemas radiculares com galhas são os sintomas típicos de parasitismo (Nyczepir \& Becker, 1998). Não há quase referências às raças de $M$. incognita identificadas, mas, na Flórida (EUA), população tida como da raça 3 tem se reproduzido inclusive em cultivares resistentes (Sherman et al., 1991). Recentemente, todavia, Nyczepir et al. (1998) determinaram, por técnicas bioquímicas e morfometria, que, na verdade, tal população não é de nenhuma das principais espécies conhecidas, ou seja, M. arenaria, M. hapla, M. incognita e M. javanica.

Em Nematologia é relativamente complexa a determinação de níveis limiares de dano econômico, mas Lownsbery (1959) afirmou que população inicial da ordem de 
cinco juvenis de segundo estádio de $M$. incognita já poderia reduzir a massa fresca de plântulas do pessegueiro 'Lovell' após 3 meses da inoculação.

Barker \& Clayton (1973), na Carolina do Norte (EUA), verificaram que os nematóides mais freqüentes em pomares amostrados foram Mesocriconema xenoplax e Meloidogyne incognita. Na África do Sul, Meyer (1976) verificou que Pratylenchus foi o gênero mais freqüente durante levantamento nematológico, embora destacasse que espécies de Meloidogyne muitas vezes ocorriam associadas a plantas de porte reduzido e que morriam lentamente.

O nematóide anelado Mesocriconema xenoplax tem importância ímpar para Prunus por estar relacionado a uma doença complexa chamada "vida curta do pessegueiro" (VCP), ou "Peach Tree Short Life" (PTSL) em inglês. O parasitismo por esse nematóide predispõe a planta à injúria pelo frio e ao cancro bacteriano causado por Pseudomonas syringae pv. syringae van Hall. Essa bactéria ainda não ocorre em pessegueiro associada à doença no Brasil (Gomes, 2001). Caracteriza-se pela morte de plantas no final do inverno e início da primavera, após drástica redução da temperatura e estímulo à produção de ácido indol acético (Nyczepir et al., 1983). Mesmo sob condições estéreis, M. xenoplax danifica significativamente raízes secundárias e terciárias (Nyczepir et al., 1987). Outras espécies de Mesocriconema ocorrem em pomares de pêssego tais como M. curvatum (Raski, 1952) Loof \& de Grisse, 1989 e M. rustica (Micoletzky, 1915) Loof \& de Grisse, 1989, porém apenas M. xenoplax está envolvido com a expressão da doença (Nyczepir \& Becker, 1998).

$\mathrm{Na}$ Europa, principalmente na região do Mar Mediterrâneo, e nos Estados Unidos (sudeste e Califórnia), $P$. vulnus causa sérios prejuízos, destruindo o parênquima da raiz e reduzindo o crescimento da planta, o que conduz a um declínio sem perspectivas de recuperação. Barker \& Clayton (1969) verificaram que de seis espécies de Pratylenchus testadas, apenas $P$. penetrans e $P$. vulnus apresentaram níveis altos de reprodução em pessegueiros. Essas duas espécies são agentes causais da doença do replantio em muitas partes do mundo. O mal caracteriza-se pela redução no crescimento e amarelecimento de árvores, normalmente acompanhada de necrose de raízes (Nyczepir \& Halbrendt, 1993). 
Em outro estudo, Stokes (1966) demonstrou que altos níveis populacionais de $P$. brachyurus pode também afetar o crescimento do pessegueiro.

Espécies de Xiphinema têm sido encontradas associadas a pessegueiros, porém em níveis populacionais considerados baixos. Alimentam-se sobre as pontas das raízes podendo impedir um desenvolvimento normal do sistema radicular (Pinochet, 1992). Além dos danos diretos que podem causar, algumas espécies do "grupo do $X$. americanum" e $X$. rivesi são vetores potenciais dos vírus do mosaico amarelo do pessegueiro e da mancha anelar do tomateiro, podendo também causar sérios prejuízos indiretos (Nyczepir, 1991; Gomes, 2001).

No Brasil, a primeira citação de nematóides atacando pessegueiros foi de Lordello \& Zamith (1960b) que determinaram as presenças de M. incognita, Xiphinema elongatum S. Stekhoven \& Teunissen, 1938 e X. krugi em raízes de pessegueiros oriundas de Ouro Preto, MG e Piracicaba, SP. Posteriormente, determinou-se a ocorrência de $P$. vulnus de raízes de pessegueiro em pomar de Monte Alegre do Sul (Lordello, 1973)

Em Minas Gerais, Aphelenchoides sp., Criconema sp., Helicotylenchus sp., $H$. dihystera, Mesocriconema sp., M. xenoplax, Trichodorus sp., Tylenchorhynchus sp., Tylenchus sp., Xiphinema sp. e X. brevicollum Lordello \& da Costa, 1961 ocorreram em amostras de solo obtidas junto a pessegueiros. Na rizosfera de ameixeiras, encontraramse $H$. dihystera, M. onoense, M. peruensiformis (de Grisse, 1967) Loof \& de Grisse, 1989, M. xenoplax e X. brasiliense Lordello, 1951 (Ferraz, 1980). Mais recentemente, na região comumente chamada de Sul de Minas, Maximiniano et al. (1999) identificaram Aorolaimus sp., Discocriconemella degrissei Loof \& Sharma, 1980, D. repleta Pinochet \& Raski, 1976, Hemicycliophora poranga Monteiro \& Lordello, 1978, H. dihystera, Meloidogyne incognita, Mesocriconema curvatum, M. palustris (Luc, 1970) Loof \& de Grisse, 1989, M. sphaerocephalum, M. xenoplax, P. brachyurus, P. thornei, T. semipenetrans, $X$. brasiliense, $X$. brevicollum e $X$. krugi em associação com pessegueiros durante levantamento nematológico. Souza et al. (1999) acrescentaram a essa lista Aphelenchoides sp. e Meloidogyne arenaria. 
No Estado de São Paulo, Monteiro et al. (1990) detectaram M. xenoplax em solo de pessegueiro com fortes sintomas de declínio. Aparentemente, esse é o único relato de plantas com sintomas semelhantes à VCP em São Paulo. No Rio Grande do Sul, a situação é diferente. Carneiro et al. (1993) amostraram vários pomares na região da Encosta do Sudoeste assinalando Helicotylenchus spp., Meloidogyne incognita, M. javanica, Mesocriconema xenoplax e espécie não identificada do "grupo do Xiphinema americanum". Os nematóides de galhas e M. xenoplax foram considerados os mais freqüentes e daninhos. Determinou-se correlação positiva e significativa entre a presença de M. xenoplax e a ocorrência de morte precoce de pessegueiros (VCP) na região. Gomes et al. (2000) relataram parasitismo de M. xenoplax no Rio Grande do Sul também em ameixeiras com evidentes sintomas de VCP, no município de Pelotas; no pomar ocorria infestação associada de nematóides de galhas, inclusive em níveis populacionais mais elevados que os do nematóide anelado. A seleção de genótipos resistentes e a rotação de culturas com plantas não hospedeiras ou más hospedeiras desses nematóides foram recomendadas visando, respectivamente, a ocupação e a recuperação de áreas já infestadas para fins de formação de novos pomares. As espécies de Xiphinema também são por vezes encontradas em altas populações, mas sem causar dano aparente às plantas. Além disso, até o momento, não há relatos de nepoviroses transmitidas por esses longidorídeos no Brasil.

Nos últimos anos, o umezeiro tem sido estudado como nova alternativa de portaenxerto condicionante de nanismo em pessegueiro (Dall'Orto et al., 1992). Não foram encontradas referências na literatura mundial a respeito de parasitismo ou associação dessa planta com nematóides, à exceção do relato de Sherman \& Lyrene (1983) de que Prunus mume (Sieb) Sieb \& Succ. parece ter altos níveis de resistência a Meloidogyne spp., o que possibilitaria a sua utilização prática como porta-enxerto. 


\subsection{Reação de fruteiras ao parasitismo por nematóides}

Por se tratarem de cultivos perenes, o controle de nematóides fitoparasitos em áreas comerciais de produção de fruteiras de clima subtropical e temperado fica, no geral, restrito a um pequeno número de medidas, capazes de conciliar eficiência, viabilidade econômica e baixos riscos de contaminação do ambiente. Entre os métodos mais estudados no mundo inclui-se o controle varietal, ou seja, a obtenção, por melhoramento genético, de genótipos que apresentem reações de resistência ou tolerância às mais importantes espécies de nematóides.

Segundo Trudgill (1991), resistência é o efeito de genes da planta hospedeira que previnem (pré-infeccional) ou restringem (pós-infeccional) a reprodução do nematóide em seus tecidos; a resistência é atributo altamente desejável, embora haja casos em que uma forte pressão de seleção, principalmente entre nematóides de reprodução anfimítica, pode levar ao aparecimento de novas raças ou biótipos, altamente virulentos, capazes de causar a perda ou "quebra" de tal característica após certo número de anos. Já a tolerância refere-se à habilidade natural da planta, geneticamente controlada, de suportar (ou recuperar-se de) os danos eventualmente causados por nematóides e produzir bem; no entanto, como é usual ocorrer certo grau de reprodução do nematóide em plantas tolerantes, estas no geral não se prestam à inclusão em programas de rotação de culturas.

No presente item, serão apresentadas as informações relativas aos estudos

pertinentes à caracterização da reação de fruteiras subtropicais e temperadas frente a nematóides encontradas na literatura especializada consultada. Nesse sentido, é oportuno esclarecer desde logo que se encontraram raras referências ao assunto para a maioria das fruteiras e, para o caquizeiro e a nogueira-macadâmia, nenhum trabalho pôde ser selecionado. A exceção foi representada pelo grupo das prunóideas, em particular o pessegueiro, para o qual já se dispõe de considerável número de pesquisas desenvolvidas em relação ao melhoramento genético de porta-enxertos visando principalmente resistência ou tolerância a espécies dos gêneros Meloidogyne e Pratylenchus. 


\subsubsection{Amoreira-preta e framboeseira}

No Canadá, Vrain \& Daubeny (1986) conseguiram selecionar dois genótipos de framboeseira, as cultivares Nootka e Dalhousie Lake, com boas características de resistência a Pratylenchus penetrans, considerada a mais daninha das espécies de Pratylenchus à cultura no país. Posteriormente, Vrain et al. (1994) verificaram que outra cultivar, Chilliwack, foi tolerante ao nematóide, podendo representar boa alternativa para uso prático ou para inclusão em novas etapas do programa de melhoramento.

\subsubsection{Goiabeira}

Em trabalho de seleção de porta-enxertos conduzido em Cuba, Diaz-Silveira (1975) destacou a elevada resistência a Meloidogyne spp. apresentada por $P$. friedrichsthalianum. Mais tarde, Gonzalvez (1989) relatou que, de todas as espécies de Psidium por ele testadas, somente $P$. catteleianum Sabine e P. friedrichsthalianum mostraram resistência a $M$. incognita raça 2 , caracterizada por baixas infestações radiculares e produção de menor número de ovos por massa de ovos. Tal conclusão contraria, pelo menos aparentemente, a de Gonzales \& Sourd (1982), que qualificaram a reação de $P$. friedrichsthalianum como de moderada tolerância a $M$. incognita raça 2; na verdade, Gonzalves referiu-se a uma possível resistência do genótipo mas reconheceu claramente ocorrer reprodução do parasito nas raízes, utilizando inclusive o parâmetro de menor número de ovos por massa na avaliação, o que sugere poder tratar-se de fato de material com certa tolerância ao nematóide. Por outro lado, Cuadra \& Quincosa (1982) haviam caracterizado como de suscetibilidade a reação de $P$. catteleianum frente a $M$. incognita raça 2, configurando-se neste caso efetiva discrepância em relação à observação de Gonzalves. Segundo vários autores, essas variações nas respostas parecem estar principalmente associadas às diferentes raças dos nematóides envolvidas nos estudos desenvolvidos, nem sempre identificadas com a necessária precisão.

$\mathrm{Na}$ Venezuela, Matheus et al. (1999) confirmaram recentemente observações contidas em trabalhos anteriores que davam conta da elevada resistência de $P$. 
friedrichsthalianum a nematóides de galhas. Esses autores inocularam plantas desse porta-enxerto e de quatro genótipos promissores de $P$. guajava, referidos como S8, S9, S10 e S11, com Meloidogyne incognita raça 1 e realizaram detalhado estudo histopatológico do material. Verificaram que o nematóide parasitou com sucesso as raízes de S8, S10 e S11, observando células gigantes típicas e todas as demais alterações anatômicas normalmente induzidas no cilindro vascular durante o desenvolvimento das fêmeas. Em oposição, nos casos de S9 e $P$. friedrichsthalianum, não se observaram espécimes do parasito no interior das raízes e tanto os elementos do floema como do xilema apresentavam-se perfeitamente organizados. Tendo em vista que todos os genótipos estudados vinham produzindo bem em áreas infestadas, consideraram S8, S10 e S11 tolerantes e S9 e $P$. friedrichsthalianum resistentes, prestando-se bem a serem empregados como porta-enxertos.

\subsubsection{Macieira}

Em trabalho mais antigo, Tufts \& Day (1934) relataram que plântulas de $M$. sylvestris cv. Ranier não foram parasitadas por nematóides de galhas (à época designados genericamente como Heterodera marioni, hoje Meloidogyne spp.) em estudo de inoculação de plantas sob condições experimentais controladas.

Pinochet et al. (1992) verificaram que os porta-enxertos 'EM-9' e 'EM-106' foram bons hospedeiros de Pratylenchus vulnus. Em outro estudo, com diferentes isolados desse mesmo nematóide, Pinochet et al. (1993) observaram grande variação na patogenicidade, desde nenhum efeito evidente até a supressão no crescimento da cultivar M-26; todos os isolados reproduziram bem nessa cultivar.

Sharma et al. (1992), em experimento conduzido em vasos, incluindo quatro níveis populacionais iniciais de juvenis de $M$. incognita, verificaram que Malus ("crab apple") mostrou-se imune a esse nematóide.

\subsubsection{Marmeleiro}


Tufts \& Day (1934) verificaram que não se formaram galhas radiculares em estacas enraizadas das cultivares Rea, Orange, Burbank, Angers, S.P.I. 33214 e East Malling após 2 anos de cultivo em canteiros uniformemente infestados com Heterodera marioni (= Meloidogyne spp.). Entretanto, pouco antes, Buhrer et al. (1933) haviam relatado a suscetibilidade de marmeleiros referidos como 'A', 'B' e 'D' a nematóides de galhas.

Pinochet et al. (1990), em pesquisa sobre a reação de diferentes fruteiras a $M$. incognita, demonstraram a resistência do marmeleiro 'Provence'. Não se observaram galhas ou nematóide nas raízes após 120 dias de inoculação das plantas com 5.000 ovos. Apenas 70 exemplares foram extraídos do solo do vaso, resultado que não diferiu estatisticamente da ameixeira 'Mariana 2624', considerada imune ao parasito.

\subsubsection{Nespereira}

Em pesquisa sobre a reação de porta-enxertos de diferentes fruteiras a $P$. vulnus, Pinochet (1992) considerou a nespereira 'Nadal' boa hospedeira desse nematóide.

\subsubsection{Oliveira}

Meloidogyne incognita e M. javanica reduziram drasticamente o crescimento de plântulas das cultivares Ascolano e Sevillano em estudos de casa de vegetação; a cultivar Manzanillo foi apenas levemente afetada, apresentando reação de tolerância. Muitas galhas bem visíveis foram incitadas, principalmente nas extremidades das raízes, a partir de onde eram emitidas novas radicelas. As três cultivares foram resistentes a $M$. arenaria e M. hapla (Lamberti \& Baines, 1969). No Egito, estudo semelhante envolvendo uma cultivar não identificada confirmou a oliveira como boa hospedeira de M. javanica, proporcionando taxa de crescimento populacional de nove vezes; todavia, as galhas observadas eram muito pequenas e o comportamento foi de tolerância, com pequena redução no crescimento das plantas inoculadas (Diab \& El-Eraki, 1968). 
Ridolfi et al. (1998) verificaram, na Itália, que as concentrações de fenóis nas raízes e folhas de oliveiras apresenta forte correlação com a reação evidenciada em relação ao parasitismo por nematóides de galhas do gênero Meloidogyne, sendo maiores nos genótipos tidos como resistentes que nos suscetíveis.

Sasanelli et al. (1999), também na Itália, realizaram experimento com vasos em casa de vegetação visando caracterizar as reações das oliveiras 'FS 17' e 'DA 12 I' (esta bastante usada como porta-enxerto na região do Mediterrâneo) frente ao parasitismo por

Xiphinema index, quando inoculadas com níveis populacionais iniciais de 0, 10, 20, 40 e 80 fêmeas por planta. Em ambos os casos, o nematóide conseguiu parasitar as plantas e reproduzir, mas as taxas de multiplicação foram baixas. O impacto sobre o crescimento foi muito mais evidente em 'DA 12 I', em que os tratamentos envolvendo plantas inoculadas apresentaram sempre valores de massa fresca total (raízes + parte aérea) significativamente menores que o do tratamento testemunha, sem inoculação; em 'FS 17' não se observaram quaisquer diferenças relativamente aos parâmetros de crescimento aferidos. Os dois genótipos foram considerados hospedeiros pouco ou não favoráveis ao nematóide em função das baixas capacidades de reprodução determinadas, sendo 'FS 17' definido como resistente e 'DA 12 I' como suscetível ou intolerante.

\subsubsection{Pereira}

Procurando avaliar a reação de dez cultivares de pereira frente a Heterodera marioni (= Meloidogyne spp.), Tufts \& Day (1934) observaram desde "ausência" até a ocorrência de "moderadas infestações". Por outro lado, Lownsbery et al. (1959) citaram genericamente pereiras como resistentes a $M$. incognita e P. vulnus. Pinochet et al. (1990) avaliaram a reação da pereira 'OHF', dentre outras fruteiras, frente a cinco populações espanholas de $M$. incognita, considerando-a resistente. Na mesma linha de resultados, Santamour \& Riedel (1993) consideraram P. calleryana também resistente a Meloidogyne spp.

Townshend (1990) observou redução no crescimento de raízes e da parte aérea em plântulas de pereira 'Bartlett', após seis semanas de cultivo em solo artificialmente 
infestado com 16 exemplares de $P$. penetrans por grama. Pinochet et al. $(1991 ; 1992)$ verificaram que a pereira 'OHF-333' foi boa hospedeira de $P$. vulnus, tendo as massas frescas de raízes e da parte aérea marcantemente diminuídas em comparação a plantas testemunhas quando inoculadas individualmente com 2.000 nematóides e avaliadas após 15 meses.

\subsubsection{Pessegueiro e outros Prunus}

A elevada suscetibilidade dessas fruteiras e o conseqüente potencial de prejuízos devidos a Meloidogyne spp., Pratylenchus vulnus e Mesocriconema xenoplax têm motivado intensivas pesquisas no sentido de se encontrar porta-enxertos que apresentem, a um só tempo, boas características agronômicas e resistência genética, de preferência múltipla, a nematóides.

\subsubsection{Resistência a Meloidogyne spp.}

Os primeiros estudos a respeito da resistência de pessegueiros e ameixeiras a espécies de Meloidogyne apareceram nas décadas de 1920 e 1930 (Sharpe et al., 1969). Desenvolveram-se na ocasião trabalhos experimentais em canteiros uniformemente infestados com Heterodera marioni (= Meloidogyne spp). Em um desses estudos, Tufts \& Day (1934) selecionaram os genótipos 'Bokhara', 'Shalil', 'S.P.I. 55885', 'S.P.I. 55886' e 'S.P.I. 55888' com nenhuma ou muito poucas galhas, considerando-os resistentes. Trabalhando com M. incognita acrita, Hansen et al. (1956) obtiveram diversos genótipos resistentes oriundos do cruzamento de 'Bokhara' com diferentes genótipos de pêssegos de flores brancas. Em 1957, verificou-se a resistência de 'Okinawa' e em 1959 de 'Nemaguard', frente a M. incognita e M. javanica (Sharpe et al., 1969). A alta resistência de 'Okinawa' em relação a populações de nematóides de galhas foi comprovada sucessivamente em experimentos sob condições controladas desenvolvidos na Autrália (Burdett et al., 1963), em Chipre (Phillis, 1989) e na Itália (Siniscalco et al., 1976). Neste último trabalho, também 'Nemaguard' e 'S-37' mostraram- 
se resistentes às populações italianas de M. incognita e M. javanica. Em Israel, Minz \& Cohn (1962) já haviam relatado que 'S-37' permitia alguma reprodução de $M$. javanica em vasos, mas no campo, apresentava comportamento geral de resistência. Esses dois autores ainda destacaram a aparente imunidade do damasco (P. armeniaca L.) 'Klabi' e a suscetibilidade dos genótipos 'Shalil', 'Beladi' e 'Elberta' em relação a M. javanica.

Em 1966, em área de pesquisas na Flórida (EUA), foi observada a ocorrência de um biótipo de Meloidogyne capaz de reproduzir em 'Nemaguard' e 'Okinawa' (Young \& Sherman, 1977). Sherman et al. (1981) expuseram a subseqüente evolução do programa de melhoramento do pessegueiro na Flórida visando resistência a esse biótipo, identificado posteriormente como sendo M. incognita raça 3 (Sherman \& Lyrene, 1983), que culminou com o lançamento de uma nova cultivar, Flordaguard. Entre outras qualidades, essa cultivar apresentava resistência a $M$. javanica e ao referido biótipo, baixa exigência em relação ao frio e folhas de cor vermelha, o que facilitava a distinção entre a cultivar de copa e o porta-enxerto (Sherman et al., 1991).

$\mathrm{Na}$ França e Espanha, grupos de pesquisa têm conseguido resultados promissores com diferentes híbridos interespecíficos oriundos de cruzamentos de amendoeira $(P$. amygdalus Batsch.) 'Garfí' com pessegueiro ( $P$. persica) 'Nemared', originando os genótipos denominados ' $\mathrm{G}$ x N', dentre outros. Além da altamente desejável resistência múltipla a Meloidogyne spp., esses genótipos apresentam bom vigor, folha de cor vermelha, resistência a seca e à toxidez por excesso de ferro (Scotto La Massèse et al., 1984; Pinochet et al., 1989; 1996; 1999; Marull \& Pinochet, 1991; Marull et al., 1991; 1994; Fernández et al., 1994; Esmenjaud et al., 1994; 1997; Pinochet, 1997; Felipe \& Gómez-Aparisi, 1997).

Estudando a herança da resistência, Weinberger et al. (1943) verificaram que 'Yunnan' e 'Shalil' apresentavam resistência do tipo dominância. Sharpe et al. (1969) verificaram que 'Okinawa' possuía resistência monofatorial dominante para $M$. incognita enquanto para M. javanica dois ou mais genes dominantes estavam envolvidos. Kochba \& Spiegel-Roy (1972), estudando esse aspecto em 'Okinawa' confirmaram a herança do tipo dominância e acrescentaram que essa cultivar apresentava um fator citoplasmático envolvido no mecanismo, pois híbridos de amendoeiras altamente suscetíveis cruzados 
com 'Okinawa' mostravam dominância completa para a resistência a $M$. javanica. Esmenjaud et al. (1997) concluíram que há pelo menos quatro sistemas genéticos envolvidos com a resistência: um herdado de 'Shalil', que condiciona resistência a $M$. arenaria e M. javanica; outro de 'Nemaguard', citado por Sharpe et al. (1969); um terceiro, evidenciado em amendoeiras da série 'Alnem', citado por Kochba \& SpiegelRoy (1972); e o quarto e último, de Prunophora, que confere resistência a todas as quatro principais espécies do gênero e ao biótipo da Flórida. Recentemente, Lu et al. (2000) demonstraram que a resistência de 'Nemared' (originado de 'Nemaguard') a $M$. incognita é controlada por dois genes dominantes (Mi e Mij) e a M. javanica por um simples gene dominante $(M i j)$. Esse último gene confere, pois, resistência a ambas as espécies.

Quanto ao mecanismo de resistência, Malo (1967) verificou que os juvenis de $M$. javanica penetram nas raízes de 'Okinawa', porém oito a dez dias após ocorre reação local de hipersensibilidade resultando na prematura destruição da célula nutridora e, conseqüentemente, o nematóide acaba morrendo antes de completar o desenvolvimento. Marull et al. (1994) verificaram que, em ' $G$ x N 9', o parasitismo por M. javanica induz formação de área necrótica ao redor do sítio de alimentação, isolando-o por uma barreira compacta de células em cujas paredes ocorre alta concentração de calose.

Segundo Miller (1997), o único porta-enxerto de pessegueiro reconhecido como tolerante ao importantíssimo nematóide anelado Mesocriconema xenoplax (ver item 2.2.8.3), chamado Guardian, é hospedeiro desfavorável a Meloidogyne spp., embora nele possam se formar galhas quando cultivado em solo infestado. Recentemente, Nyczepir et al. (1999) avaliaram a reprodução de $M$. incognita raça 3 e $M$. javanica em plantas dessa cultivar, formadas a partir de sementes de diferentes origens, e, com base nos números de massas de ovos, de ovos por planta, de ovos por massa de ovos e de ovos por grama de raízes, concluíram que realmente se trata de hospedeiro muito desfavorável a ambas as espécies.

Alguns fatores podem influenciar a resistência a Meloidogyne spp. A temperatura é um deles. Em altas temperaturas, ocorre um aumento na suscetibilidade segundo Esmenjaud et al. (1997) e uma diminuição parcial da resistência (Pinochet, 1995). 
Estudos comprovaram que a idade da planta também influencia essa característica; assim, Fernández et al. (1995) verificaram que plantas com dois meses e meio de idade da cultivar Barrier reagiram como moderadamente resistentes a M. incognita e plantas mais velhas, com um ano, como resistentes, sugerindo ser necessário um período de maturação fisiológica do tecido radicular para a completa expressão da resistência. Pinochet (1995) acrescentou que o estado nutricional da planta, o $\mathrm{pH}$ e a salinidade do solo também podem afetar a resistência.

No Brasil, antes da introdução do pessegueiro 'Okinawa' em 1968 (Rigitano et al., 1975b), os porta-enxertos utilizados provinham de caroços de frutos de cultivares utilizados pela indústria de conserva, principalmente 'Rei da Conserva', 'Diamante' e 'Capdebosq' (Nogueira, 1985; Penteado, 1986).

Menten et al. (1977) foram os primeiros a avaliar a reação de porta-enxertos de pessegueiros no Brasil. Trabalhando com uma população mista de $M$. arenaria e $M$. incognita em São Paulo, verificaram a suscetibilidade de 'Rei da Conserva', 'Talismã', 'Cristal' e 'Biuti', contrastando com a alta resistência de 'Okinawa'. Mauch et al. (1991), trabalhando com $M$. incognita no Rio Grande do Sul, relataram a suscetibilidade de 'Magno', a intolerância de Aldrighi' e 'Capdeboscq' e a resistência da ameixeira 'Myrabolano 29C', bem como de genótipos originados de cruzamentos envolvendo 'Okinawa', 'Nemaguard' e 'S-37'. Scherb et al. (1993), em Minas Gerais, confirmaram a resistência de 'Ókinawa' e de 'R15-2' a M. incognita. Por fim, curiosamente, Fachinello et al. (2000), também no Rio Grande do Sul, consideraram 'Aldrighi' resistente a Meloidogyne spp.

\subsubsection{Resistência a Pratylenchus vulnus}

Diferente dos nematóides de galhas, vários estudos desenvolvidos durante a última década têm comprovado a grande dificuldade de se obter genótipos resistentes a Pratylenchus vulnus (Marull \& Pinochet, 1991; Pinochet et al., 1991; 1992; 1996). Os genótipos considerados resistentes não se enxertam ou não se cruzam com Prunus comerciais (Pinochet, 1995). Ledbetter (1992) testou mais de 150 genótipos de Prunus 
utilizados como porta-enxertos da coleção do Departamento de Agricultura dos Estados Unidos (USDA) e verificou, após 5 meses de inoculação artificial, que uma ameixeira nativa americana, 'Bruce', hospedava muito menos nematóides que 'Mariana 2624' e 'Nemaguard', tidas como referências. No momento, um dos objetivos do melhoramento é incorporar a conhecida resistência de 'Nemaguard' a espécies de Meloidogyne a esse porta-enxerto.

\subsubsection{Resistência a Mesocriconema xenoplax}

Quanto a Mesocriconema xenoplax, até o momento o melhor porta-enxerto disponível é ‘Guardian', lançado em 1995, com o objetivo de gradualmente substituir os antigos padrões, 'Lovell' e 'Hallford'. Trata-se de porta-enxerto tolerante ao nematóide anelado, e não resistente; adicionalmente, é também mau hospedeiro de nematóides de galhas (Miller, 1997).

Carneiro et al. (1998), no Brasil, avaliaram a reprodução de uma população sulriograndense de M. xenoplax em dez porta-enxertos de Prunus em condições de telado. Todos os genótipos testados tiveram fator de reprodução maior do que 1, ou seja, foram considerados suscetíveis. Entretanto, 'Flordaguard' e 'Lovell' foram menos suscetíveis que os demais. 


\section{MATERIAL E MÉTODOS}

\subsection{Levantamento de Nematóides Parasitos de Fruteiras}

\subsubsection{Locais de coleta}

Realizou-se levantamento da fauna de nematóides fitoparasitos em 149 amostras obtidas de: i) pomares comerciais distribuídos por 24 municípios localizados nas principais regiões produtoras de fruteiras de clima subtropical e temperado do Estado de São Paulo, definidos a partir dos resultados de levantamento censitário estadual das unidades de produção agrícola (Pino, 1997) ii) quatro Estações Experimentais do Instituto Agronômico de Campinas (IAC), que desenvolvem pesquisas com essas fruteiras e disponibilizam plantas matrizes a viveiristas e produtores; iii) dois Núcleos de Produção de Mudas e Matrizes da Coordenadoria de Assistência Técnica Integral (CATI); iv) propriedade agrícola no município de Marmelópolis, Estado de Minas Gerais, considerada um dos últimos redutos de produção de marmelo do país; e v) mudas de outras diferentes origens (Tabela 1e Figura 1).

\subsubsection{Coleta de amostras}

Procedeu-se ao levantamento durante a primavera e o verão das safras 1998/99, 1999/2000 e 2000/01, períodos nos quais as plantas estudadas, bem como os nematóides, apresentavam atividade mais intensa.

A coleta teve como procedimento padrão o caminhar em zigue-zague, definindose uma árvore ao acaso, eliminando-se as plantas daninhas do local com enxadão e coletando-se, também com enxadão, sub-amostra de solo e raízes em ponto na 


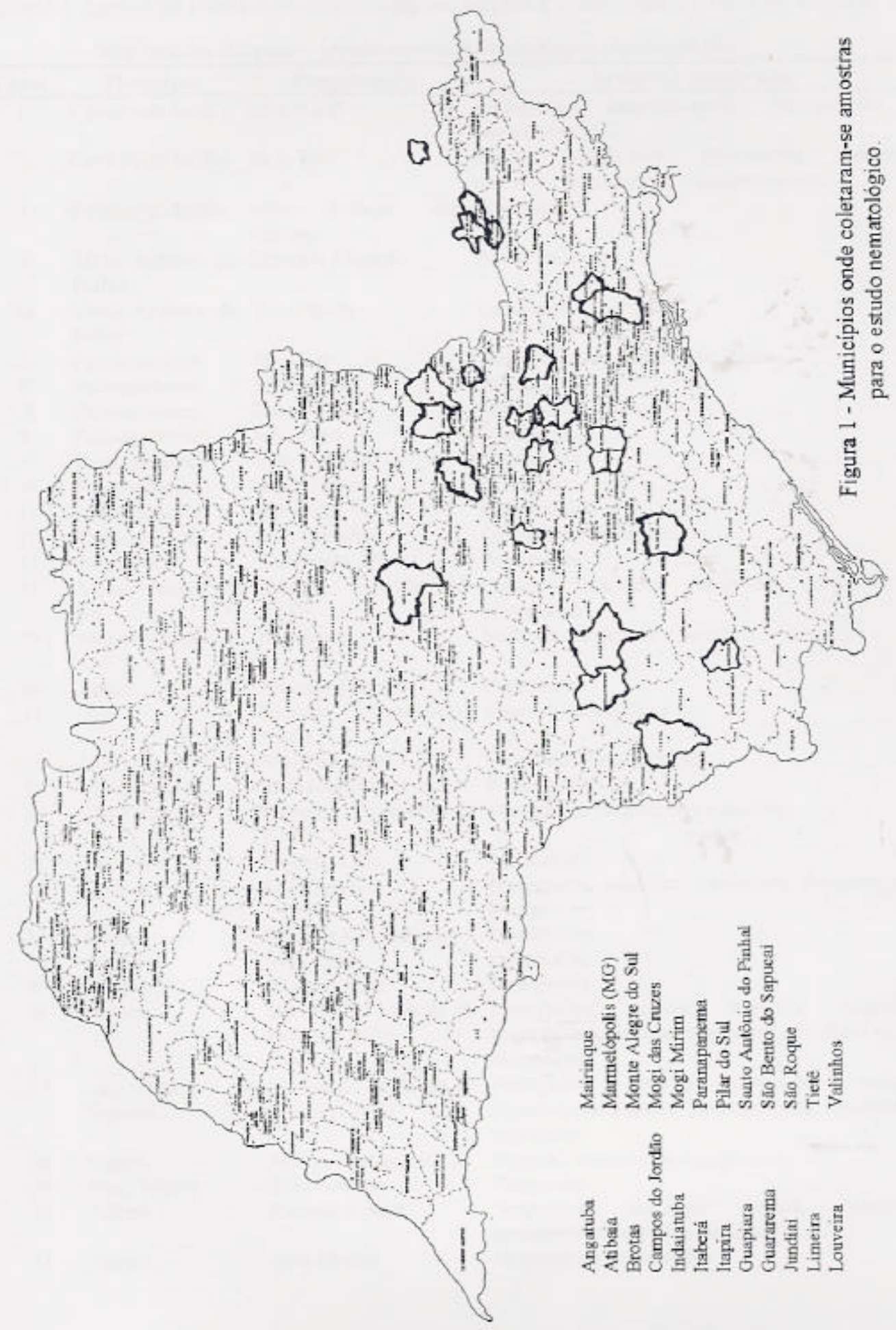


Tabela 1. Locais de coleta com respectivos municípios e propriedades e tipos de fruteiras amostradas durante o levantamento nematológico desenvolvido.

\begin{tabular}{|c|c|c|c|}
\hline Local & Município & Propriedade & Fruteiras amostradas \\
\hline 1 & Campos do Jordão & Sítio Natal & $\begin{array}{l}\text { Pessegueiro, amoreira-preta, framboeseira } \\
\text { marmeleiro }\end{array}$ \\
\hline 2 & Campos do Jordão & Sítio Tani & $\begin{array}{l}\text { Pereira, caquizeiro, pessegueiro, macieira, } \\
\text { umezeiro, framboeseira e amoreira-preta. }\end{array}$ \\
\hline 3 & Campos do Jordão & $\begin{array}{l}\text { Sítio Refúgio dos } \\
\text { Campos }\end{array}$ & Framboeseira \\
\hline 4 & $\begin{array}{l}\text { Santo Antônio do } \\
\text { Pinhal }\end{array}$ & Sítio São Miguel & Amoreira-preta \\
\hline $4 a$ & $\begin{array}{l}\text { Santo Antônio do } \\
\text { Pinhal }\end{array}$ & Sítio Okada & Caquizeiro \\
\hline 5 & Paranapanema & Sítio Iuri & Macieira, pessegueiro e caquizeiro \\
\hline 6 & Paranapanema & Sítio Timo & Pessegueiro \\
\hline 7 & Paranapanema & Sítio Hubber & Pessegueiro \\
\hline 8 & Paranapanema & Sítio Nico & Pessegueiro \\
\hline 9 & Paranapanema & Sítio Teodorus & Pessegueiro \\
\hline 10 & Paranapanema & Sítio Geraldo & Pessegueiro \\
\hline 11 & Paranapanema & Sítio João & Pessegueiro \\
\hline 12 & Paranapanema & Sítio Benedito & Pessegueiro e umezeiro \\
\hline 13 & Angatuba & Sítio Paulo Afonso & Pessegueiro \\
\hline 14 & $\begin{array}{l}\text { Monte Alegre do } \\
\text { Sul }\end{array}$ & $\begin{array}{l}\text { Estação } \text { Experimental } \\
\text { (IAC) }\end{array}$ & $\begin{array}{l}\text { Pereira, caquizeiro, nespereira, macieira e } \\
\text { pessegueiro }\end{array}$ \\
\hline 15 & $\begin{array}{l}\text { Monte Alegre do } \\
\text { Sul }\end{array}$ & Sítio Lopes & Macieira, nespereira e pereira \\
\hline 16 & Brotas & Fazenda Taperão & Pessegueiro \\
\hline 17 & Tietê & $\begin{array}{l}\text { Estação } \quad \text { Experimental } \\
\text { (IAC) }\end{array}$ & Nogueira-macadâmia \\
\hline 18 & Mairinque & Sítio Buldecas & Caquizeiro e pessegueiro \\
\hline 19 & Mairinque & Sítio Iragami & Pessegueiro \\
\hline 20 & São Roque & $\begin{array}{l}\text { Estação } \text { Experimental } \\
\text { (IAC) }\end{array}$ & Marmeleiro, caquizeiro e umezeiro \\
\hline 21 & Limeira & Fazenda Citra & Marmeleiro \\
\hline 22 & Guapiara & Sítio Scatolin & $\begin{array}{l}\text { Pessegueiro, macieira, caquizeiro, framboeseira e } \\
\text { pereira }\end{array}$ \\
\hline 23 & Guapiara & Fazenda São Francisco & Pessegueiro \\
\hline 24 & Guapiara & Sítio Ichida & Pessegueiro \\
\hline 25 & Guapiara & Sítio Prudente & Pessegueiro \\
\hline 26 & Itaberá & $\begin{array}{l}\text { Núcleo de Produção de } \\
\text { Mudas (CATI) }\end{array}$ & $\begin{array}{l}\text { Pessegueiro, pereira, macieira, caquizeiro, nogueira- } \\
\text { macadâmia, nespereira, amoreira-preta e marmeleiro }\end{array}$ \\
\hline 27 & $\begin{array}{l}\text { São Bento do } \\
\text { Sapucaí }\end{array}$ & $\begin{array}{l}\text { Núcleo de Produção de } \\
\text { Mudas (CATI) }\end{array}$ & $\begin{array}{l}\text { Pessegueiro, oliveira, nespereira, macieira, } \\
\text { nogueira-macadâmia, amoreira-preta, marmeleiro, } \\
\text { caquizeiro }\end{array}$ \\
\hline 28 & Itapira & Sítio das Palmeiras & Nogueira-macadâmia e caquizeiro \\
\hline 29 & Mogi Mirim & Sítio Fabiano & Caquizeiro \\
\hline 30 & Atibaia & Fazenda Cristal & $\begin{array}{l}\text { Nespereira, macieira, pereira, } \\
\text { pessegueiro e nogueira-macadâmia }\end{array}$ \\
\hline 31 & Atibaia & Sítio Ohashi & Nespereira e pessegueiro \\
\hline
\end{tabular}


Tabela 1. Locais de coleta com respectivos municípios e propriedades e tipos de fruteiras amostradas durante o levantamento nematológico desenvolvido.

\begin{tabular}{clll}
\hline Local & \multicolumn{1}{c}{ Município } & \multicolumn{1}{c}{ Propriedade } & \multicolumn{1}{c}{ Fruteiras amostradas } \\
\hline 32 & Atibaia & Sítio Ide & Pessegueiro e nespereira \\
33 & Pilar do Sul & Sítio Ito & Caquizeiro e pessegueiro \\
34 & Pilar do Sul & Sítio Kawatsu & Pessegueiro e macieira \\
35 & Pilar do Sul & Sítio Jacaré & Caquizeiro e pereira \\
36 & Mogi das Cruzes & & Caquizeiro \\
37 & Mogi das Cruzes & & Caquizeiro \\
38 & Mogi das Cruzes & Sítio Tupy & Caquizeiro \\
39 & Mogi das Cruzes & Sítio Junishiro & Caquizeiro e nespereira \\
40 & Guararema & Casa da Agricultura & Caquizeiro \\
41 & Indaiatuba & & Caquizeiro \\
42 & Marmelópolis & & Marmeleiro \\
43 & Jundiaí & Estação Experimental & Pessegueiro, caquizeiro, nogueira-macadâmia, \\
& & (IAC) & marmeleiro, nespereira e pereira \\
44 & Louveira & Sítio Brusque & Pessegueiro e caquizeiro \\
45 & Louveira & Sítio Chinoda & Pessegueiro \\
46 & Louveira & Sítio Urbano & Caquizeiro \\
47 & Louveira & Sítio Amorim & Pessegueiro \\
48 & Louveira & Sítio Steck I & Caquizeiro \\
49 & Louveira & Sítio Steck II & Pessegueiro \\
50 & Valinhos & Sítio Trombeta I & Pessegueiro \\
51 & Valinhos & Sítio Trombeta II & Pessegueiro \\
\hline
\end{tabular}

projeção da copa, à profundidade de 0 a $20 \mathrm{~cm}$; nessa ocasião, por exame visual, selecionaram-se e removeram-se eventuais raízes de plantas invasoras ainda presentes. Dez sub-amostras por talhão, com características edáficas e culturais homogêneas e mesma cultivar de porta-enxerto, formaram uma amostra composta de 800 a $1000 \mathrm{~g}$ de solo e 10 a 50 g de raízes. Acondicionou-se cada amostra composta em saco plástico provido de etiqueta externa contendo dados gerais sobre o local de coleta e respectivo histórico de uso agrícola da área; as amostras foram mantidas em caixas de isopor, para prevenir aquecimento por exposição ao sol durante o transporte até o laboratório. 


\subsubsection{Extração e fixação dos nematóides}

As amostras foram processadas em até 48 horas após a coleta, no máximo. Para a extração, homogeneizaram-se as amostras manualmente e depois separaram-se alíquotas de $250 \mathrm{~cm}^{3}$ de solo e de $5 \mathrm{~g}$ de raízes. Para solo e raízes, os métodos adotados foram, respectivamente, o da flutuação em centrífuga (Jenkins, 1964) e do liquidificador associado à flutuação em centrífuga (Coolen \& D’Herde, 1972), ambos de uso rotineiro nos laboratórios nematológicos. Fêmeas de Meloidogyne foram extraídas das amostras de raízes, intercalando peneira de malha 60 sobreposta à de 500 após a centrifugação. Submeteu-se a suspensão contendo os nematóides extraídos ao aquecimento gradual à $60^{\circ} \mathrm{C}$ por 3 minutos em aquecedor tipo banho-maria, para relaxamento e morte dos espécimes. Para a fixação, acrescentou-se formol comercial, diluindo-se de modo a se obter formalina a 4\%. O volume final das suspensões foi ajustado para $10 \mathrm{~mL}$.

\subsubsection{Determinação da densidade populacional e identificação}

Estimaram-se os níveis populacionais de cada gênero de nematóides mediante contagens em alíquotas de $1 \mathrm{~mL}$ em lâmina de Peters, ao microscópio propriamente dito. Para a identificação dos gêneros e espécies, montaram-se lâminas semi-permanentes em formalina a 4\%. Levaram-se em conta nessa tarefa vários caracteres morfológicos e morfométricos de valor diagnóstico, resumidos na Tabela 2. Para o exame microscópico dos espécimes, utilizou-se microscópio biológico com câmara clara e ocular micrométrica acopladas. Baseou-se, para as identificações, em várias publicações consideradas referências taxonômicas aos diferentes gêneros de fitonematóides, que estão incluídas na bibliografia final. Incluíram-se na categoria 'nematóides não parasitos de plantas' (NNPP) as formas dos gêneros Aphelenchoides, Aphelenchus, Tylenchus obtidas do solo, por não terem comprovada ação patogênica sobre raízes de plantas.

Para a identificação específica de Meloidogyne, prepararam-se e examinaram-se cortes da região perineal das fêmeas conforme os procedimentos descritos em Hartman \& Sasser (1985) e Taylor \& Sasser (1978). 


\subsubsection{Bio-ensaios e determinação da raça de Meloidogyne}

Visando detectar a ocorrência de nematóides de galhas (Meloidogyne spp.) no solo em baixos níveis populacionais e aumentá-los para fins de identificação aos níveis de espécie e raça, acondicionou-se o solo remanescente de cada amostra em vaso plástico e para ele transplantou-se uma muda de tomateiro 'Rutgers'. Após 40 dias, em média, as plantas foram retiradas dos vasos e examinadas quanto à presença de galhas radiculares. Destas, removeram-se fêmeas com suas respectivas massas de ovos, que foram mantidas em recipientes rasos de vidro tipo siracusa, de $2 \mathrm{~cm}$ de diâmetro, para a identificação específica, feita como relatado em 3.1.4. Para cada caso positivo de infecção por espécie que encerrava diferentes raças (a saber, $M$. incognita ou $M$. arenaria), selecionou-se uma das massas de ovos produzidas pelas fêmeas empregadas na identificação e inoculou-se em copo plástico contendo solo esterilizado e no qual vegetava uma muda de tomateiro 'Rutgers'. Após 60 dias, os ovos formados foram extraídos pelo método de Hussey \& Barker (1973), modificado por Bonetti \& Ferraz (1981), e re-inoculados em plantas hospedeiras diferenciais para a determinação da raça, conforme estabelecido no protocolo de Taylor \& Sasser (1978).

\subsection{Determinação da capacidade reprodutiva de nematóides de galhas em diferentes fruteiras}

Os experimentos a que se refere este item foram desenvolvidos em laboratório, telados e casa de vegetação do Laboratório de Nematologia do Centro Experimental do Instituto Biológico, em Campinas (SP).

Tabela 2. Caracteres morfométricos utilizados na identificação dos nematóides obtidos durante o levantamento e respectivas siglas. 


\begin{tabular}{lc}
\hline \multicolumn{1}{c}{ Caracteres } & Siglas \\
\hline Comprimento total do corpo & $\mathrm{L}$ \\
Comprimento do estilete & $\mathrm{St}$ \\
Distância da abertura do canal da glândula esofagiana dorsal à base do estilete x 100/ St & $\mathrm{o}$ \\
Comprimento do corpo/maior largura do corpo (normalmente na região da vulva) & $\mathrm{a}$ \\
Comprimento do corpo/distância do término anterior do corpo ao final do esôfago & $\mathrm{b}$ \\
Comprimento do corpo/distância da extremidade anterior do corpo à extremidade posterior & \\
das glândulas esofagianas & $\mathrm{b}^{\prime}$ \\
Comprimento do corpo/comprimento da cauda & $\mathrm{c}$ \\
Comprimento da cauda/largura do corpo ao nível do ânus & $\mathrm{c}^{\prime}$ \\
Número total de anéis do corpo contado pelo lado dorsal & $\mathrm{R}$ \\
Número de anéis entre a vulva e o extremo posterior do corpo & $\mathrm{Rv}$ \\
Número de anéis entre o ânus e o extremo posterior do corpo & $\mathrm{Rc}$ \\
Comprimento do espículo & $\mathrm{Esp}$ \\
Comprimento da cauda & $\mathrm{cd}$ \\
\hline
\end{tabular}

\subsubsection{Origem e formação das plantas}

Os materiais genéticos utilizados, bem como as respectivas origens, encontram-se na Tabela 3. Nos casos de 'GF 677', 'G x N 9', 'G x N 15', 'G x N 22', 'Tsukuba 1', 'Tsukuba 2', 'Tsukuba 3', 'M 9', 'MM 106' e 'Marubakaido', utilizaram-se estacas enraizadas por meio de hormônio (ácido indol butírico). Estacas herbáceas de ponteiro de 'Ébano' e 'Boisenberry' foram enraizadas em vermiculita esterilizada, sem uso de hormônios. Para as demais fruteiras, obtiveram-se sementes oriundas de frutos colhidos de uma única planta, tratadas com fungicida (nome técnico tetrametiltiuram, marca comercial Thiram 70). Germinaram-se sementes das cultivares de nespereira e nogueiramacadâmia em vasos plásticos contendo substrato (solo e areia, 1:1) esterilizado por brometo de metila $\left(150 \mathrm{~mL} / \mathrm{m}^{3}\right)$. As demais foram germinadas pelo método de quebra de dormência (Barbosa et al., 1987). 


\subsubsection{Inoculação das plantas}

Por ocasião do transplante, fez-se o corte da raiz principal de forma a padronizar o tamanho dos sistemas radiculares e estimular o desenvolvimento de raízes secundárias e terciárias, mais adequadas ao estabelecimento de sítios de alimentação pelos nematóides. Após o transplante individual em copos plásticos com capacidade para 0,5 litros de substrato (solo e areia, 1:1) esterilizado por brometo de metila $\left(150 \mathrm{~mL} / \mathrm{m}^{3}\right)$, as plântulas permaneceram em telado por período médio de 30 dias. Subseqüentemente, selecionaram-se plantas com aproximadamente igual tamanho, transferindo-as para a casa de vegetação, onde foram inoculadas, individualmente, com 5000 ovos de Meloidogyne incognita raça 2 ou $M$. javanica. As suspensões de ovos dessas duas espécies, utilizadas como inóculos, foram obtidas por extração a partir de raízes de tomateiros 'Rutgers' previamente infectados, também segundo a técnica de Hussey \& Barker (1973), modificada por Bonetti \& Ferraz (1981). As populações originais de $M$. incognita raça 2 e $M$. javanica empregadas no estudo foram obtidas respectivamente de raízes de pessegueiro 'GF 677', oriundas de Brotas (SP), e de tomateiro 'Carmen', de Monte Mor (SP).

\subsubsection{Delineamento estatístico e condução do experimento}

O delineamento estatístico foi inteiramente casualizado, contando o experimento de $M$. incognita com 28 tratamentos e o de $M$. javanica com 30, representados pelos genótipos de fruteiras, ambos com 8 repetições. A parcela constituiu-se de copo plástico contendo uma planta. Tomateiros 'Rutgers' foram também inoculados para verificação da viabilidade dos inóculos utilizados.

Realizaram-se adubações quinzenais com fertilizante líquido (marca Ouro Verde) à razão de $20 \mathrm{~mL} /$ planta da solução preparada, ou seja, de $8 \mathrm{~mL}$ da solução concentrada 6-6-8/2 L de água). Regaram-se as plantas sempre que necessário, bem como monitorouse a temperatura da casa de vegetação para que não excedesse $30^{\circ} \mathrm{C}$. 
Tabela 3. Espécies botânicas, genótipos e origens dos materiais propagativos estudados.

\begin{tabular}{|c|c|c|}
\hline Espécie botânica & Genótipos & Origem \\
\hline $\begin{array}{ll}\text { Chaenomeles japonica } & \text { Lindl. } \\
\text { (marmeleiro do Japão) }\end{array}$ & & FEC \\
\hline $\begin{array}{l}\text { Eriobotrya japonica Lindley } \\
\text { (nespereira) }\end{array}$ & $\begin{array}{l}\text { 'Mizuho', 'Néctar de Cristal', 'Parmogi' e 'Precoce de } \\
\text { Campinas' }\end{array}$ & EEJd \\
\hline $\begin{array}{l}\text { Macadamia integrifolia Maid. e } \\
\text { Bethe (nogueira-macadâmia) }\end{array}$ & ‘Kakedo’, ‘Keaudo', ‘Keauhou’, ‘Keaumi’ e ‘Waialua' & EEJd \\
\hline $\begin{array}{l}\text { Malus x domestica Borkh. } \\
\text { (macieira) }\end{array}$ & 'M-9' e 'MM-106' & EEC \\
\hline $\begin{array}{l}\text { Malus prunifolia (Wil.) Bork. } \\
\text { (macieira) }\end{array}$ & 'Marubakaido' & EEC \\
\hline Olea europaea L. (oliveira) & 'Arbequina' & AT \\
\hline $\begin{array}{l}\text { Prunus x Mume Siebold \& } \\
\text { Zucc. (umezeiro) }\end{array}$ & & EEJd \\
\hline $\begin{array}{l}\text { Prunus persica (L.) Batsch } \\
\text { (pessegueiro) }\end{array}$ & 'Okinawa', 'Tsukuba 1', 'Tsukuba 2' e 'Tsukuba 3' & EEJd e FC \\
\hline $\begin{array}{l}\text { Prunus persica (L.) Batsch } \\
\text { (pessegueiro) x P. dulcis (Mill.) } \\
\text { Webb (amendoeira) }\end{array}$ & 'GF-677', 'GxN 9', 'GxN 15', 'GxN 22’ & AT \\
\hline Psidium guajava L. (goiabeira) & 'Kumagai', 'Paluma' e 'Sassaoka' & EEJd \\
\hline $\begin{array}{l}\text { Pyrus calleryana Dec. (pereira } \\
\text { oriental) }\end{array}$ & 'Taiwan Nashi-C' & $\mathrm{CF}$ \\
\hline $\begin{array}{l}\text { Pyrus communis L. (pereira } \\
\text { comum) }\end{array}$ & 'D’água' & NPMSB \\
\hline Rubus sp. (amoreira-preta) & ‘Ébano’’ & NPMSB \\
\hline Rubus idaeus L. (framboeseira) & 'Boisenberry' & $\mathrm{SN}$ \\
\hline \multicolumn{3}{|c|}{$\begin{array}{l}\text { AT: Agromilhora Taperão Ltda. (Brotas, SP); CF: Centro de Fruticultura - IAC (Campinas, SP); EEJd } \\
\text { Estação Experimental de Jundiaí - IAC (Campinas, SP); EEC: Estação Experimental de Caçador } \\
\text { EPAGRI (Caçador, SC); FC: Fruticultura Cristal (Atibaia, SP); FEC: Fazenda Experimental de Caldas } \\
\text { EPAMIG (Caldas, MG); NPMSB: Núcleo de Produção de Mudas de São Bento do Sapucaí - CATI (Sã } \\
\text { Bento do Sapucaí, SP); SN: Sítio Natal (Campos do Jordão, SP). }\end{array}$} \\
\hline
\end{tabular}

\subsubsection{Avaliações}

Aos 120 dias da inoculação, desenvasaram-se as plantas e separaram-se os sistemas radiculares das partes aéreas com tesoura; as raízes foram lavadas sob água corrente e deixadas para secar por 30 minutos à sombra, determinando-se os valores de massa fresca. Subseqüentemente, foram submetidas à coloração com 'phloxine B' para evidenciar as massas de ovos externas e determinaram-se os números de galhas e de massas de ovos, obtendo-se os índices de galhas (IG) e de massas de ovos (IMO), todos esses procedimentos segundo as recomendações de Taylor \& Sasser (1978). Para determinar o número de nematóides (ovos + juvenis de segundo estádio) no sistema 
radicular (NSR) e por grama de raiz (NGR), processaram-se os sistemas radiculares pela técnica do liquidificador associada à flutuação em centrífuga (Coolen \& D’Herde, 1972), estimando-se tais parâmetros em alíquota de $1 \mathrm{~mL}$ em lâmina de Peters, ao microscópio propriamente dito.

\subsubsection{Bio-ensaios}

Nos casos das cultivares de goiabeira e oliveira, instalaram-se bio-ensaios a fim de confirmar as reações verificadas nos experimentos. Para isso, estacas enraizadas dos quatro genótipos foram transplantados, individualmente, para recipientes plásticos contendo 1,8 L de substrato (item 3.2.2) infestado contendo em média 20.000 juvenis de segundo estádio do nematóide. Realizou-se um bio-ensaio em delineamento inteiramente casualizado, com quatro tratamentos/genótipos e quatro repetições, para cada espécie de nematóide. Avaliaram-se os índices de galhas e de massas de ovos de cada planta aos 120 dias do transplante, seguindo a mesma metodologia indicada em 3.2.4.

\subsubsection{Análise dos dados}

Analisaram-se estatisticamente os dados aplicando-se o teste $\mathrm{F}$ na análise da variância e o teste de Tukey no caso de pelo menos duas médias de tratamentos diferirem entre si. 


\subsection{Determinação da capacidade reprodutiva de nematóides de galhas em caquizeiros}

Desenvolveram-se os dois experimentos a que se refere este item, um para $M$. incognita raça 2 e outro para M. javanica, em época diferente dos anteriores (item 3.2) por questão ligada à disponibilidade de material propagativo.

\subsubsection{Origem e formação das plantas}

Obtiveram-se sementes de sete genótipos de caqui, sendo seis de D. kaki ['Pomelo', junto à Estação Experimental de Jundiaí (IAC); 'Regina', 'Rama Forte', 'Coral' e 'Fuyuanna', junto à Estação Experimental de Monte Alegre do Sul (IAC); e 'Kyoto', junto à Fruticultura Cristal] e um de D. virginiana, junto à Fruticultura Cristal.

Germinaram-se as sementes em vasos plásticos contendo substrato esterilizado (item 3.2.2). Cada planta foi transplantada para um copo plástico contendo $0,5 \mathrm{~L}$ de substrato.

Seguiram-se semelhantes procedimentos metodológicos aos dos itens 3.2.2, 3.2.3, 3.2.4 e 3.2.6, à exceção do índice de galhas (IG) de Taylor \& Sasser (1978) que foi substituído pelo de Zeck (1971), devidamente caracterizado por Netscher \& Sikora (1990) e do número de tratamentos/cultivares, que totalizaram sete.

A escala de notas de Zeck (1971) caracteriza-se por:

0 = sistema radicular sem infestação e completo;

1 = Poucas galhas de tamanho reduzido detectadas com exame detalhado;

2 = Galhas pequenas porém numerosas e facilmente detectadas;

3 = Numerosas pequenas galhas, algumas grandes, função das raízes não seriamente afetadas;

4 = Numerosas pequenas galhas, algumas bem grandes, maioria das raízes não seriamente afetadas;

$5=25 \%$ do sistema radicular com galhas e não funcionais;

$6=50 \%$ do sistema radicular com galhas e não funcionais; 
$7=75 \%$ do sistema radicular com galhas e não funcionais;

8 = Nenhuma raiz saudável, nutrição da planta interrompida;

$9=$ Sistema radicular completamente cheio de galhas, planta morrendo e,

$10=$ Planta e raízes mortas.

\subsection{Patogenicidade de Meloidogyne incognita ao caquizeiro}

\subsubsection{Origem e formação das plantas}

Obtiveram-se mudas do caquizeiro 'Kyoto', com $10 \mathrm{~cm}$ de altura e cerca de 60 dias após a emergência, junto à empresa Fruticultura Cristal. Transplantou-se cada muda para um copo plástico contendo 0,5 L de substrato esterilizado (item 3.2.2).

\subsubsection{Delineamento estatístico}

O delineamento adotado foi inteiramente casualizado com seis tratamentos, representados por níveis populacionais $(\mathrm{Pi})$ crescentes e logaritmicamente eqüidistantes: 0, 160, 800, 4 000, 20 000, 100000 nematóides por parcela, com oito repetições. A parcela constituiu-se de saco plástico (16 cm de diâmetro por $28 \mathrm{~cm}$ de altura) de $6,5 \mathrm{~L}$ de capacidade preenchido com 6 L de substrato (item 3.2.2), em que se cultivou uma planta.

\subsubsection{Inoculação das plantas e avaliação}

Sessenta dias após o transplante, procedeu-se à inoculação dos seis níveis populacionais iniciais em dois orifícios feitos ao redor do colo da planta. Obteve-se a suspensão-inóculo de Meloidogyne incognita raça 2 seguindo-se o mesmo processo descrito em 3.2.2. Vinte dias após a inoculação, as plantas foram transplantadas para os sacos plásticos. A partir daí, adotaram-se os mesmos tratos culturais aplicados nos demais experimentos. Após 6 meses da inoculação, determinaram-se o diâmetro do caule 
ao nível do solo e a altura das plantas utilizando-se paquímetro e régua, respectivamente. Em seguida, retiraram-se as plantas dos recipientes e separaram-se os sistemas radiculares das partes aéreas com tesoura; as raízes foram lavadas sob água corrente e deixadas para secar por 30 minutos à sombra. Colocaram-se então, separadamente, tanto os sistemas radiculares como os órgãos aéreos de cada planta em sacos especiais de papel, providos de perfurações laterais, devidamente etiquetados, que foram mantidos à 68-70 ${ }^{\circ} \mathrm{C}$ em estufa de secagem com circulação forçada de ar até se obter os respectivos valores de massa seca.

Os dados obtidos foram submetidos à análise de variância e, quando ocorreram diferenças significativas, procedeu-se à análise de regressão utilizando-se o programa SAS/ANOVA (SAS Institute, 1988). 


\section{RESULTADOS}

\subsection{Levantamento de espécies}

Diferentes espécies de nematóides fitoparasitos coabitam a rizosfera de fruteiras de clima subtropical e temperado. Identificaram-se 24 espécies pertencentes a 11 gêneros em 149 amostras compostas coletadas no Estados de São Paulo e Minas Gerais (Tabela 4).

Nematóides de vida livre, ou seja, não parasitos de plantas, também foram observados na grande maioria das amostras. Do total de amostras de solo, apenas quatro $(2,7 \%)$ não continham nematóides desse grupo ou fitoparasitos. Não se detectaram nematóides fitoparasitos em 28 amostras (19,0\%).

Identificaram-se espécies de fitonematóides pertencentes a gêneros das famílias Criconematidae, Heteroderidae, Hoplolaimidae, Longidoridae, Pratylenchidae e Tylenchulidae. Os três gêneros mais freqüentes foram Helicotylenchus, Mesocriconema e Xiphinema, presentes respectivamente em 60,4, 55,0 e 30,2 \% das amostras (Tabela 5).

\section{Família Criconematidae}

Encontrou-se M. xenoplax em 57 amostras, ou seja, 38,3\% do total (Tabela 6). Foi a segunda espécie mais freqüente, ocorrendo em 41 amostras de pessegueiros, três de amoreiras-pretas, três de caquizeiros, uma de framboeseira, três de macieiras, três de pereiras e três de umezeiros. Excetuado o pessegueiro, as demais fruteiras foram consideradas novas hospedeiras para a literatura nacional. Portanto, não se detectou $M$. xenoplax em marmeleiros, nespereiras, nogueiras-macadâmia e oliveiras. 
Tabela 4. Densidade populacional de nematóides de amostras de solo e raízes de fruteiras de clima subtropical e temperado.

\begin{tabular}{|c|c|c|c|c|c|c|c|c|c|c|c|c|}
\hline Fruteira & Local & Aorol* & Helic & Hemic & Meloi & Mesocric & Praty & Rotyl & Scut & Tylenc & Xiphi & NNPP \\
\hline \multirow[t]{5}{*}{ Amoreira } & 1 & & $360(70)^{* *}$ & & & 40 & & & $130(30)$ & & & 1560 \\
\hline & 2 & & 430 & & $500(120)$ & $450(20)$ & & & & & & 2220 \\
\hline & $4 * * *$ & & $1600(80)$ & & & 200 & & & & & 160 & 1540 \\
\hline & 26 & & & & & & & & & & & 60 \\
\hline & 27 & & & & & & & & & & & 210 \\
\hline Caquizeiro & 2 & & 160 & & & 40 & & & & 1920 & 160 & 1900 \\
\hline \multirow[t]{6}{*}{ Mudas } & $4 a$ & & 30 & & & 60 & & & & 80 & 30 & 1090 \\
\hline & 5 & & 240 & & & & & & & $14160(120)$ & & 960 \\
\hline & 14 & & 320 & & & & & & & $\begin{array}{l}370 \\
(20)\end{array}$ & & 830 \\
\hline & 18 & & 480 & & & & 120 & & $100(60)$ & & 180 & 1040 \\
\hline & 22 & & $80(10)$ & & & 80 & & & & $\begin{array}{c}11880 \\
(13240)\end{array}$ & 20 & 3020 \\
\hline & $26-1$ & & & & & & & & & $840(170)$ & & 1440 \\
\hline \multirow[t]{8}{*}{ Mudas } & $26-2$ & & 30 & & & & & & & & & 490 \\
\hline & $26-3$ & & 160 & & & $200(10)$ & & & & & 40 & 1280 \\
\hline & $27-1$ & & & & & & & & & & & \\
\hline & $27-2$ & & 210 & & & & & & & & & 850 \\
\hline & $27-3$ & & & & & & & & & & & 290 \\
\hline & 28 & & & & & & & & & $1350(590)$ & & 610 \\
\hline & 29 & & & & & & & & & $360(1960)$ & & 980 \\
\hline & $30-1$ & & 610 & & & 10 & & & & & & 2160 \\
\hline \multirow[t]{9}{*}{ Mudas } & $30-2$ & & 60 & & & & & & & $110(50)$ & & 980 \\
\hline & $33-1$ & & & & & & & & & $630(4400)$ & 80 & 390 \\
\hline & $33-2$ & & & & & & & & & & & 6000 \\
\hline & 35 & & & & & & & & & $3720(6960)$ & & 400 \\
\hline & 36 & & & & & & & & & $40(560)$ & & 110 \\
\hline & 37 & & & & & & & & & & & 100 \\
\hline & 38 & & & & & & & & & $140(400)$ & & 210 \\
\hline & 39 & & & & & & & & & & & 40 \\
\hline & 40 & & & & (220) & & & & & & & \\
\hline
\end{tabular}


Tabela 4. Densidade populacional de nematóides de amostras de solo e raízes de fruteiras de clima subtropical e temperado.

\begin{tabular}{|c|c|c|c|c|c|c|c|c|c|c|c|c|}
\hline Fruteira & Local & Aorol & Helic & Hemic & Meloi & Mesocric & Praty & Rotyl & Scut & Tylenc & Xiphi & NNPP \\
\hline \multirow[t]{4}{*}{ Caquizeiro } & $\begin{array}{l}41 \\
43\end{array}$ & & & & & & & & & $1280(640)$ & & 2040 \\
\hline & 44 & & & & & & & & & $670(120)$ & & 320 \\
\hline & 46 & & & & & & & & & & & 1310 \\
\hline & 48 & & & & & & & & & & & 20 \\
\hline \multirow[t]{3}{*}{ Framboeseira } & 1 & & $460(20)$ & & & 60 & & & & & & 2540 \\
\hline & 2 & & & & & 60 & & & & & & 1210 \\
\hline & 3 & & & & & 80 & & & & & & 1680 \\
\hline \multirow[t]{12}{*}{ Macieira } & 2 & & & 30 & & $760(80)$ & & & & & 10 & 1120 \\
\hline & $5-1$ & & 400 & & & & & & & & & 880 \\
\hline & $5-2$ & & $180(1200)$ & & & & & & & & & 360 \\
\hline & $5-3$ & & 40 & & & & & & & & 120 & 520 \\
\hline & $5-4$ & & 60 & & & 40 & & & & & & 1040 \\
\hline & 14 & & 100 & & & 40 & & & & & 10 & 150 \\
\hline & 15 & & 520 & & & & & & & & 120 & 960 \\
\hline & 22 & 130 & 400 & & & 40 & & & & & 10 & 110 \\
\hline & 26 & & 20 & & & 30 & & & & & 40 & 1400 \\
\hline & 27 & & & & & & & & & & & 310 \\
\hline & 30 & & 80 & & & & & & & & & 1030 \\
\hline & 34 & & & & & & & & & & & 240 \\
\hline \multirow[t]{2}{*}{ Marmeleiro } & 1 & & 180 & & & & & & & & & 640 \\
\hline & 20 & & 130 & & & 70 & & & & & 30 & 1600 \\
\hline \multirow[t]{5}{*}{ Mudas } & 21 & & 20 & & & & & 80 & & & & 200 \\
\hline & 26 & & & & $960(310)$ & & & & & & & 2680 \\
\hline & 27 & & 220 & & & $810(110)$ & & & & & 20 & 1390 \\
\hline & 42 & & 70 & 430 & & $120(10)$ & & & & & & 240 \\
\hline & 43 & & & & & & & & & & & 200 \\
\hline \multirow[t]{3}{*}{ Nespereira } & 14 & & 90 & & & & 60 & & & & 40 & 970 \\
\hline & 15 & & & & & & & & & & 30 & 830 \\
\hline & 26 & & 40 & & & & & & & & 10 & 720 \\
\hline
\end{tabular}


Tabela 4. Densidade populacional de nematóides de amostras de solo e raízes de fruteiras de clima subtropical e temperado.

\begin{tabular}{|c|c|c|c|c|c|c|c|c|c|c|c|c|}
\hline Fruteira & Local & Aorol & Helic & Hemic & Meloi & Mesocric & Praty & Rotyl & Scut & Tylenc & Xiphi & NNPP \\
\hline \multirow[t]{7}{*}{ Nespereira } & 27 & & & & & 20 & & & & & 10 & 1440 \\
\hline & $30-1$ & & 30 & & & 40 & & & & & & 330 \\
\hline & $30-2$ & & 70 & & & 30 & & & & & & 360 \\
\hline & 31 & & & & & & & & & & & \\
\hline & 32 & & & & & 20 & & & & & & 730 \\
\hline & 39 & & & & & & & & & & & 60 \\
\hline & 43 & & & & & & & & & & & \\
\hline \multirow[t]{4}{*}{ Nog. mac. } & 17 & & 20 & & & 40 & & & & & 50 & 2170 \\
\hline & 26 & & & & & & & & & & 10 & 670 \\
\hline & 27 & & 280 & & & & & & & & 20 & 400 \\
\hline & $28-1$ & & & & & & & & & & & \\
\hline \multirow[t]{3}{*}{ Mudas } & $28-2$ & & & & & & & & & & & 100 \\
\hline & 30 & & & & & & & & & & & 120 \\
\hline & 43 & & & & & & & & & & & 880 \\
\hline Oliveira & 27 & & 10 & & $80(60)$ & 10 & & & & & & 760 \\
\hline \multirow[t]{4}{*}{ Pereira } & 2 & & 360 & & & 50 & & & & 680 & 120 & 1440 \\
\hline & 14 & & 570 & & & 50 & & & & & & 1230 \\
\hline & 15 & & 20 & & & 20 & & & & & 20 & 1210 \\
\hline & 22 & & 240 & 450 & & 20 & & & & & 30 & 710 \\
\hline \multirow[t]{5}{*}{ Mudas } & $26-1$ & & & & & & & & & & & 200 \\
\hline & $26-2$ & & & & & & & & & & & 1510 \\
\hline & 30 & & 60 & & & 40 & & & & & & 520 \\
\hline & 35 & & 570 & & & 200 & & & & & & 80 \\
\hline & 43 & & 400 & & & 1200 & & & & & & 1440 \\
\hline \multirow[t]{7}{*}{ Pessegueiro } & $1-1$ & & 80 & & & 120 & & & & & 40 & 620 \\
\hline & $1-2$ & & & & & 2440 & & & & & 1680 & 1240 \\
\hline & $2-1$ & & 360 & & & 160 & & & & & 40 & 1840 \\
\hline & $2-2$ & & 90 & & & 180 & & & & & & 1080 \\
\hline & $5-1$ & & 100 & & & 20 & & & & & & 500 \\
\hline & $5-2$ & & 20 & & & 320 & & & & & & 990 \\
\hline & 6 & & 800 & & & 280 & & & & & & 3240 \\
\hline
\end{tabular}


Tabela 4. Densidade populacional de nematóides de amostras de solo e raízes de fruteiras de clima subtropical e temperado.

\begin{tabular}{|c|c|c|c|c|c|c|c|c|c|c|c|c|}
\hline Fruteira & Local & Aorol & Helic & Hemic & Meloi & Mesocric & Praty & Rotyl & Scut & Tylenc & Xiphi & NNPP \\
\hline \multirow[t]{20}{*}{ Pessegueiro } & 7 & & 180 & & & 280 & & & & & & 1020 \\
\hline & $8-1$ & & 40 & & & & & & & & & 1360 \\
\hline & $8-2$ & & & & & & & & & & & 680 \\
\hline & $8-3$ & & 270 & & & 80 & & & & & 220 & 760 \\
\hline & $8-4$ & & 160 & & & & & & & & & 1480 \\
\hline & $8-5$ & & 560 & & & 400 & & & & & 20 & 2400 \\
\hline & $8-6$ & & 1560 & & & 10 & & & & & & 1280 \\
\hline & $9-1$ & & 10 & & & 760 & & & & & 20 & 1280 \\
\hline & $9-2$ & & 160 & & & 260 & & & & & & 1700 \\
\hline & $9-3$ & & & & & 20 & & & & & & 380 \\
\hline & $9-4$ & & & & & 160 & & & & & & 100 \\
\hline & $10-1$ & & & & & & & & & & 10 & 2170 \\
\hline & $10-2$ & & 200 & & & & & & & & & 1150 \\
\hline & 11 & & 40 & & & 520 & & & & & & 1280 \\
\hline & 12 & & 2000 & & & 160 & & & & & & 680 \\
\hline & 13 & & 360 & & & 380 & & & & & 10 & 1520 \\
\hline & 14 & & & & & 760 & & & & & 20 & 1420 \\
\hline & $16-1$ & & 10 & & & & & & & & & 490 \\
\hline & $16-2$ & & & & $2150(610)$ & 20 & & & & & & 1560 \\
\hline & $16-3$ & & 50 & & & & & & & & & 1290 \\
\hline \multirow[t]{11}{*}{ Mudas } & $16-4$ & & & & & & & & & & & 200 \\
\hline & $18-1$ & & 10 & & & 30 & & & & & 80 & 500 \\
\hline & $18-2$ & & 510 & & & 40 & & & & & & 590 \\
\hline & 19 & & 310 & & & 420 & & & 100 & & 130 & 800 \\
\hline & $22-1$ & & 360 & & & 250 & & & & & 10 & 290 \\
\hline & $22-2$ & & 90 & & $\begin{array}{c}40 \\
(10)\end{array}$ & 10 & & & & & & 490 \\
\hline & $22-3$ & & 630 & 330 & & 210 & & & & & & 600 \\
\hline & $22-4$ & & 50 & & $\begin{array}{c}12.080 \\
(690)\end{array}$ & 30 & & & & & 10 & 370 \\
\hline & $23-1$ & & 320 & & $110(20)$ & 170 & & & & & & 1030 \\
\hline & $23-2$ & & 260 & & & 40 & & & & & & 40 \\
\hline & 24 & & 20 & & & 80 & & & & & & 230 \\
\hline
\end{tabular}


Tabela 4. Densidade populacional de nematóides de amostras de solo e raízes de fruteiras de clima subtropical e temperado.

\begin{tabular}{|c|c|c|c|c|c|c|c|c|c|c|c|c|}
\hline Fruteira & Local & Aorol & Helic & Hemic & Meloi & Mesocric & Praty & Rotyl & Scut & Tylenc & Xiphi & NNPP \\
\hline \multirow[t]{4}{*}{ Pessegueiro } & $25-1$ & 210 & & & & 400 & & 130 & & & & 450 \\
\hline & $25-2$ & 690 & & & $40(10)$ & 800 & & & & & 10 & 4800 \\
\hline & 26 & & 200 & & $10(10)$ & 10 & & & & & 50 & 600 \\
\hline & 27 & & 90 & & & 10 & & & & & & 950 \\
\hline \multirow[t]{20}{*}{ Mudas } & $30-1$ & & & & & & & & & & & 80 \\
\hline & $30-2$ & & & & & 20 & & & & & & 200 \\
\hline & $30-3$ & & 20 & & & & & & & & 10 & 340 \\
\hline & $30-4$ & & & & & & & & & & & 4440 \\
\hline & $30-5$ & & & & & & & & & & & 1230 \\
\hline & $30-6$ & & 10 & & & & & & & & 10 & 2320 \\
\hline & $31-1$ & & & & & 960 & & & & & & 1200 \\
\hline & $31-2$ & & 10 & & & 320 & & & & & & 680 \\
\hline & $31-3$ & & 200 & & $\begin{array}{c}2400 \\
(1030)\end{array}$ & 560 & & & & & & 690 \\
\hline & $32-1$ & & 20 & & & 640 & & & & & 10 & 700 \\
\hline & $32-2$ & & & & & 210 & & & & & 200 & 690 \\
\hline & 33 & & 310 & & & 220 & & & & & & 430 \\
\hline & 34 & & & & & 200 & & & & & & 600 \\
\hline & 43 & & & & & 100 & & & 60 & & & 1110 \\
\hline & 44 & & 120 & & & 200 & & & & & & 610 \\
\hline & 45 & & 240 & & & 400 & & & & & & 320 \\
\hline & 47 & & 920 & & & 160 & & & & & & 730 \\
\hline & 49 & & 40 & & & & & & & & & 240 \\
\hline & 50 & & & & & & & & & & & 600 \\
\hline & 51 & & 240 & & & & & & & & & 1110 \\
\hline \multirow[t]{4}{*}{ Umezeiro } & $2-1$ & & & & & 130 & & & & & & 1640 \\
\hline & $2-2$ & & 40 & & & 120 & & & & & & 640 \\
\hline & 12 & & 840 & & & 120 & & & & & & 1320 \\
\hline & 20 & & 90 & & & 400 & & & & & 30 & 1110 \\
\hline
\end{tabular}

*Aorolaimus, Helicotylenchus, Hemicycliophora, Meloidogyne, Mesocriconema, Pratylenchus, Rotylenchulus, Scutellonema, Tylenchulus, Xiphinema, Nematóides não parasitos de plantas.

** valor entre parêntesis refere-se a nematóides extraídos de raízes;

*** 20 Discocriconemella. 
Tabela 5. Fitonematóides identificados durante o levantamento com respectivas porcentagens de ocorrência e posição relativa ("ranking") entre os gêneros e espécies.

\begin{tabular}{|c|c|c|c|}
\hline $\begin{array}{l}\text { Gêneros e espécies } \\
\text { identificados }\end{array}$ & $\begin{array}{c}\text { Amostras } \\
\text { positivas }\end{array}$ & $\begin{array}{l}\text { Posição ("ranking") } \\
\text { entre os gêneros } \\
\text { e espécies }\end{array}$ & $\begin{array}{c}\text { Porcentagem em relação } \\
\text { ao } \\
\text { total de amostras }\end{array}$ \\
\hline Aorolaimus & 3 & 7 & 2,0 \\
\hline A. nigeriensis & 3 & 13 & 2,0 \\
\hline Discocriconemella & 1 & 9 & 0,7 \\
\hline D. degrissei & 1 & 14 & 0,7 \\
\hline Helicotylenchus & 90 & 1 & 60,4 \\
\hline Helicotylenchus spp. & 14 & 5 & 9,4 \\
\hline H. dihystera & 73 & 1 & 49,0 \\
\hline H. erythrinae & 1 & 15 & 0,7 \\
\hline H. microcephalus & 2 & 14 & 1,4 \\
\hline H. pseudorobustus & 1 & 15 & 0,7 \\
\hline Hemicycliophora & 4 & 6 & 2,7 \\
\hline H. poranga & 4 & 12 & 2,7 \\
\hline Meloidogyne & 10 & 5 & 6,7 \\
\hline M. hapla & 1 & 15 & 0,7 \\
\hline M. incognita & 8 & 9 & 5,4 \\
\hline M. javanica & 4 & 12 & 2,7 \\
\hline Mesocriconema & 82 & 2 & 55,0 \\
\hline Mesocriconema spp. & 14 & 6 & 9,4 \\
\hline M. onoense & 3 & 12 & 2,0 \\
\hline M. ornata & 3 & 12 & 2,0 \\
\hline M. sphaerocephalum & 5 & 11 & 3,4 \\
\hline M. xenoplax & 57 & 2 & 38,3 \\
\hline Pratylenchus & 2 & 8 & 1,4 \\
\hline P. brachyurus & 2 & 13 & 1,4 \\
\hline P. zeae & 2 & 13 & 1,4 \\
\hline Rotylenchulus & 2 & 8 & 1,4 \\
\hline R. reniformis & 2 & 13 & 1,4 \\
\hline Scutellonema & 3 & 7 & 2,0 \\
\hline S. brachyurus & 3 & 12 & 2,0 \\
\hline Tylenchulus & 16 & 4 & 10,7 \\
\hline T. semipenetrans & 16 & 4 & 10,7 \\
\hline Xiphinema & 45 & 3 & 30,2 \\
\hline Xiphinema spp. & 18 & 3 & 12,1 \\
\hline X. brevicollum & 10 & 8 & 6,7 \\
\hline X. elongatum & 3 & 12 & 2,0 \\
\hline X. krugi & 11 & 7 & 7,4 \\
\hline$X$. setariae & 3 & 12 & 2,0 \\
\hline$X$. surinamense & 6 & 10 & 4,0 \\
\hline
\end{tabular}


Estimaram-se 2440 espécimes por $250 \mathrm{~cm}^{3}$ de solo em Campos do Jordão, tido como o nível populacional mais alto. Os valores morfométricos obtidos foram: $\mathrm{L}=410$ a $684 \mu \mathrm{m} ; \mathrm{a}=6,8$ a 12,$3 ; \mathrm{b}=3,0$ a 6,$0 ; \mathrm{c}=23,3$ a $61 ; \mathrm{V}=90,5$ a $97,7 \%$; $\mathrm{st}=75,5$ a $89,3 \mu \mathrm{m} ; \mathrm{R}=90$ a 113 e $\mathrm{Rv}=6$ a 11,3 (Tabela 6). Tais valores mostram correspondência com as variações obtidas por diferentes autores (Raski, 1952; Sperandio, 1992). As características morfológicas mais típicas observadas nessas populações foram a presença marcante de lobos submedianos na região labial, vagina formando curva sigmóide, quando observada lateralmente, e ausência de anastomoses na cutícula. Esses caracteres, associados ao número total de anéis do corpo e comprimento do estilete, permitem diferenciar essa espécie das demais que normalmente ocorrem nos solos do Brasil. Identificaram-se outras espécies de nematóides anelados: M. onoense em macieira (Monte Alegre do Sul), oliveira (São Bento do Sapucaí) e caquizeiro (Atibaia), M. ornata em pessegueiro e macieira (Paranapanema) e M. sphaerocephalum em caquizeiro (Campos do Jordão), marmeleiro (São Roque e São Bento do Sapucaí), nespereira e pereira (Atibaia e São Bento do Sapucaí). À exceção de M. sphaerocephalum em caquizeiro, todas as outras são novas ocorrências nos citados hospedeiros para a literatura nacional. Os valores observados para essas espécies (Tabela 7) estão em concordância com os apresentados por Luc (1970). Os principais caracteres diferenciais entre essas espécies são comprimento do corpo e do estilete, número total de anéis do corpo, da vulva até o término do corpo e presença ou não de anastomoses na cutícula. Em 14 amostras, encontraram-se apenas juvenis ou muito poucos adultos de Mesocriconema, o que não permitiu a identificação específica.

Outros Criconematidae encontrados foram Discocriconemella degrissei Loof \& Sharma, 1980 em amoreira-preta em Santo Antônio do Pinhal e Hemicycliophora poranga em macieira (Campos do Jordão), marmeleiro (Marmelópolis) e pereira e pessegueiro (Guapiara) (Tabelas 4, 5 e 7). Todas as ocorrências são novas para a literatura nacional, exceto $H$. poranga em pessegueiro. 
Tabela 6. Valores morfométricos de fêmeas de Mesocriconema xenoplax obtidos a partir de espécimes coletados em fruteiras de clima subtropical e temperado*.

\begin{tabular}{|c|c|c|c|c|c|c|c|c|c|c|}
\hline Cultura & Local & $\mathbf{n}$ & $\mathbf{L}$ & $\mathbf{a}$ & b & c & V & st & $\mathbf{R}$ & Rv \\
\hline Amoreira & 1 & 1 & $\overline{531,5}$ & $\overline{9,0}$ & 4,7 & 33,3 & 91,8 & 87,0 & 97 & 7,1 \\
\hline Amoreira & 2 & 2 & 496,5 & 9,1 & 4,8 & 52,3 & 92,2 & 86,5 & 90 & 8,0 \\
\hline Amoreira & 4 & 4 & 490,0 & 8,7 & 3,0 & 23,3 & 90,6 & 87,3 & 105 & 10,0 \\
\hline Caquizeiro & 18 & 1 & 623 & 10,7 & 5,1 & 36,6 & 96,3 & 88 & 113 & 6,0 \\
\hline Caquizeiro & 22 & 3 & 531,3 & 9,1 & 4,5 & 32,3 & 96,0 & 84 & 108 & 6,7 \\
\hline Caquizeiro & $26-3$ & 2 & 621,4 & 10,1 & 3,5 & 35,2 & 95,0 & 83 & 110 & 7,0 \\
\hline Framboeseira & 3 & 1 & 529,3 & 8,9 & 4,5 & 32,3 & 97,0 & 84 & 100 & 6,8 \\
\hline Macieira & 2 & 1 & 410,0 & 7,7 & 3,2 & 25,6 & 92,4 & 87 & 112 & 10,0 \\
\hline Macieira & 22 & 2 & 556,2 & 8,4 & 3,8 & 37,4 & 97,2 & 87 & 92,9 & 7,7 \\
\hline Macieira & 26 & 3 & 546,3 & 9,4 & 4,4 & 36,4 & 96,2 & 87 & 95,7 & 8,7 \\
\hline Pereira & 14 & 1 & 610 & 12,0 & 6,0 & 46,9 & 97,0 & 87 & 103 & 6,0 \\
\hline Pereira & 35 & 1 & 623 & 10,2 & 4,5 & 34,6 & 96,6 & 87 & 104 & 7,0 \\
\hline Pereira & 43 & 2 & 463,5 & 7,9 & 3,6 & 30,9 & 97 & 88 & 103,5 & 9,0 \\
\hline Pessegueiro & $1-1$ & 3 & 546,0 & 8,5 & 3,4 & 23,7 & 90,5 & 85,3 & 99,7 & 9,7 \\
\hline Pessegueiro & $1-2$ & 4 & 609,2 & 9,5 & 4,4 & 27,7 & 91,3 & 84,2 & 98,6 & 8,7 \\
\hline Pessegueiro & $2-1$ & 4 & 481,8 & 10,1 & 3,3 & 26,8 & 95,7 & 86,8 & 101,5 & 9,0 \\
\hline Pessegueiro & $2-2$ & 4 & 587,9 & 9,6 & 3,5 & 27,9 & 93,2 & 88,8 & 100,3 & 8,9 \\
\hline Pessegueiro & $5-1$ & 3 & 443,0 & 8,2 & 3,8 & 29,5 & 94,3 & 86,3 & 102 & 9,0 \\
\hline Pessegueiro & $5-2$ & 3 & 496,7 & 9,7 & 4,4 & 25,2 & 94,0 & 83,3 & 105 & 11,3 \\
\hline Pessegueiro & 6 & 2 & 495 & 9,3 & 4,4 & 35,4 & 96 & 86,5 & 102 & 9,5 \\
\hline Pessegueiro & 7 & 1 & 430 & 7,0 & 3,1 & 43 & 94,9 & 87 & 117 & 7,0 \\
\hline Pessegueiro & $8-5$ & 1 & 429 & 7,1 & 3,2 & 47 & 98,3 & 89 & 98 & 6,9 \\
\hline Pessegueiro & $9-1$ & 3 & 456 & 8,3 & 3,9 & 17,7 & 94,2 & 88 & 100,7 & 6,0 \\
\hline Pessegueiro & $9-2$ & 1 & 610 & 10,7 & 5,0 & 35,9 & 93,9 & 83 & 112 & 7,0 \\
\hline Pessegueiro & $9-3$ & 2 & 536,5 & 9,4 & 4,5 & 37,0 & 96,5 & 88,5 & 103 & 6,5 \\
\hline Pessegueiro & $9-4$ & 1 & 496,5 & 9,1 & 4,3 & 37,9 & 98,7 & 89,5 & 100 & 7,1 \\
\hline Pessegueiro & 11 & 4 & 461 & 8,6 & 3,9 & 30,7 & 95,7 & 86,8 & 96 & 6,5 \\
\hline Pessegueiro & 12 & 2 & 534,5 & 7,6 & 3,7 & 32,6 & 98,2 & 87,9 & 99 & 7,1 \\
\hline Pessegueiro & 13 & 1 & 456,1 & 7,1 & 4,3 & 37,6 & 91,8 & 88,9 & 107 & 7,2 \\
\hline Pessegueiro & 14 & 3 & 509,3 & 9,8 & 4,2 & 29,4 & 96,0 & 84,7 & 100 & 6,3 \\
\hline Pessegueiro & $16-2$ & 3 & 556 & 9,5 & 4,2 & 34,8 & 97 & 87,7 & 97 & 9,0 \\
\hline Pessegueiro & $18-1$ & 1 & 437 & 8,7 & 3,9 & 48,6 & 95 & 87 & 113 & 8,0 \\
\hline Pessegueiro & 19 & 2 & 420 & 8,1 & 4,5 & 40 & 97 & 75,5 & 111,5 & 6,5 \\
\hline Pessegueiro & $22-1$ & 2 & 494,0 & 8,7 & 4,0 & 31,9 & 96 & 87 & 104,5 & 8,5 \\
\hline Pessegueiro & $22-2$ & 2 & 463,0 & 7,9 & 3,7 & 35,6 & 96,9 & 88 & 95,5 & 8,5 \\
\hline Pessegueiro & $22-3$ & 1 & 610 & 9,7 & 4,5 & 61 & 97 & 87 & 113 & 7,0 \\
\hline Pessegueiro & $23-1$ & 3 & 522,3 & 9,0 & 4,3 & 34,8 & 96,6 & 84,7 & 104,3 & 8,7 \\
\hline Pessegueiro & 24 & 1 & 684 & 11,2 & 5,7 & 40,2 & 97,7 & 87 & 103 & 7,0 \\
\hline Pessegueiro & $25-1$ & 1 & 603,8 & 10,2 & 6,1 & 41,2 & 98,3 & 89 & 101 & 6,9 \\
\hline Pessegueiro & $25-2$ & 1 & 684,9 & 11,2 & 5,7 & 41,3 & 97,7 & 87 & 103 & 7,0 \\
\hline Pessegueiro & 26 & 2 & 522,5 & 8,4 & 4,4 & 34,8 & 95,6 & 87 & 90,5 & 8,5 \\
\hline Pessegueiro & 27 & 1 & 603 & 12,3 & 4,9 & 37,7 & 96,3 & 89 & 94 & 7,0 \\
\hline Pessegueiro & $30-2$ & 1 & 684 & 11,2 & 5,7 & 40,2 & 97,7 & 87 & 103 & 7,0 \\
\hline Pessegueiro & $31-1$ & 2 & 523 & 8,5 & 4,2 & 29,9 & 95,4 & 88 & 106 & 8,0 \\
\hline Pessegueiro & $31-2$ & 2 & 496 & 8,3 & 3,9 & 28,3 & 95,6 & 83,5 & 98 & 8,0 \\
\hline Pessegueiro & $31-3$ & 2 & 397 & 6,8 & 3,2 & 24,1 & 95,0 & 87 & 99,5 & 6,5 \\
\hline
\end{tabular}


Tabela 6. Valores morfométricos de fêmeas de Mesocriconema xenoplax obtidos a partir de espécimes coletados em fruteiras de clima subtropical e temperado*.

\begin{tabular}{ccccccccccc}
\hline Cultura & Local & $\mathbf{n}$ & $\mathbf{L}$ & $\mathbf{a}$ & $\mathbf{b}$ & $\mathbf{c}$ & $\mathbf{V}$ & $\mathbf{s t}$ & $\mathbf{R}$ & $\mathbf{R v}$ \\
\hline Pessegueiro & $32-1$ & 3 & 501,7 & 8,2 & 4,1 & 32,8 & 96,7 & 88,3 & 110,7 & 6,3 \\
Pessegueiro & $32-2$ & 3 & 528,7 & 8,4 & 4,0 & 30,6 & 96,1 & 87 & 97,7 & 7,7 \\
Pessegueiro & 33 & 1 & 685 & 10,2 & 6,7 & 41,2 & 96,3 & 89 & 113 & 6,9 \\
Pessegueiro & 34 & 2 & 427,5 & 7,8 & 3,4 & 28,5 & 94 & 87 & 104 & 6,5 \\
Pessegueiro & 43 & 4 & 498,5 & 8,7 & 4,0 & 35,6 & 96,0 & 88,3 & 102,5 & 8,8 \\
Pessegueiro & 44 & 1 & 684,1 & 11,2 & 5,7 & 40,2 & 97,7 & 87 & 103 & 7,0 \\
Pessegueiro & 45 & 3 & 512,3 & 8,0 & 3,2 & 23,6 & 92 & 86,3 & 100 & 9,3 \\
Pessegueiro & 47 & 2 & 515 & 9,3 & 3,2 & 24,0 & 94 & 87,5 & 107 & 10,0 \\
Umezeiro & $2-1$ & 1 & 583,9 & 10,8 & 5,9 & 41,2 & 99,7 & 87 & 103 & 7,0 \\
Umezeiro & 12 & 3 & 540 & 9,4 & 4,2 & 31,2 & 96,2 & 89,3 & 95,3 & 7,3 \\
Umezeiro & 20 & 2 & 433,5 & 7,9 & 3,8 & 45,6 & 96,2 & 87,5 & 103,5 & 8,5 \\
\hline
\end{tabular}

* : "L" e "st" expressos em $\mu \mathrm{m}$; "V" expresso em termos percentuais.

Tabela 7. Valores morfométricos de fêmeas de Criconematidae encontradas associadas a fruteiras de clima subtropical e temperado durante o levantamento*.

\begin{tabular}{|c|c|c|c|c|c|c|c|c|c|c|}
\hline \multicolumn{11}{|c|}{ Hemicycliophora poranga } \\
\hline Cultura & Local & $\mathbf{n}$ & $\mathbf{L}$ & $\mathbf{a}$ & b & c & $\mathbf{c}^{\prime}$ & st & $\mathbf{R v}$ & Re \\
\hline Macieira & 2 & 3 & 917,3 & 29,6 & 5,4 & 10,9 & 4,4 & 86,2 & 281 & 34 \\
\hline Marmeleiro & 42 & 3 & 932,0 & 29,8 & 5,3 & 11,2 & 4,5 & 83,9 & 288 & 34 \\
\hline Pereira & 22 & 1 & 862,0 & 29,7 & 5,3 & 10,1 & 4,5 & 85,0 & 281 & 29 \\
\hline Pessegueiro & $22-3$ & 3 & 934,3 & 31,5 & 5,6 & 10,9 & 4,1 & 84,2 & 286 & 30 \\
\hline \multicolumn{11}{|c|}{ Discocriconemella degrissei } \\
\hline Cultura & Local & $\mathbf{n}$ & $\mathbf{L}$ & $\mathbf{a}$ & $\mathbf{b}$ & c & c' & st & $\mathbf{R}$ & $\mathbf{R v}$ \\
\hline Amoreira & 4 & 2 & 317,0 & 7,0 & 3,4 & 33,4 & - & 65 & 77 & 7,5 \\
\hline \multicolumn{11}{|c|}{ Mesocriconema onoense } \\
\hline Caquizeiro & $30-1$ & 3 & 394,3 & 10,3 & 3,9 & 16,7 & 48,3 & 93,0 & 127 & 10 \\
\hline Macieira & 14 & 4 & 463,3 & 10,0 & 3,8 & 17,2 & 50,0 & 90,2 & 121 & 9 \\
\hline Oliveira & 27 & 2 & 476,5 & 10,0 & 3,8 & 16,7 & 49,0 & 94,4 & 118 & 9 \\
\hline \multicolumn{11}{|c|}{ M. ornata } \\
\hline Macieira & $5-4$ & 2 & 490,0 & 10,7 & 5,0 & 20,4 & 52,0 & 94,4 & 89 & 6 \\
\hline Pessegueiro & $8-3$ & 1 & 501,0 & 10,9 & 9,8 & 23,9 & 51,0 & 93,0 & 90 & 6 \\
\hline Pessegueiro & $8-6$ & 3 & 487,7 & 12,0 & 4,5 & 20,6 & 52,3 & 92,0 & 87 & 7 \\
\hline \multicolumn{11}{|c|}{ M. sphaerocephalum } \\
\hline Caquizeiro & 2 & 3 & 295,7 & 8,9 & 3,4 & 34,0 & 46,7 & 89,0 & 69 & 5 \\
\hline Marmeleiro & 20 & 1 & 304,0 & 10,5 & 3,8 & 33,8 & 51,0 & 88,5 & 54 & 6 \\
\hline Marmeleiro & 27 & 3 & 324,0 & 9,9 & 3,5 & 26,3 & 55,3 & 93,2 & 69 & 5 \\
\hline Nespereira & $30-1$ & 1 & 333,0 & 10,1 & 3,7 & 27,8 & 57,0 & 90,0 & 71 & 5 \\
\hline Pereira & 30 & 3 & 325,0 & 10,8 & 3,6 & 24,4 & 34,3 & 94,7 & 62 & 5 \\
\hline
\end{tabular}

* : "L" e "st" expressos em $\mu \mathrm{m}$; "V" expresso em termos percentuais. 
Os valores morfométricos de $D$. degrissei estão em conformidade com os obtidos por Vovlas et al. (1989), exceto para “c” (33,4 vs. 32: valor máximo). Não se detectaram machos. No caso de $H$. poranga, os resultados das mensurações não diferem das caracterizações de Monteiro \& Lordello (1978), Sperandio (1992) e Costa Manso (1996), à exceção do exemplar obtido da rizosfera de pereira cujo comprimento do corpo está pouco abaixo do valor mínimo indicado por Costa Manso (1996) para tal caráter $(862,0$ vs. $880,0 \mu \mathrm{m})$. A presença do disco labial visivelmente elevado é a característica mais evidente para separar essa espécie das demais que ocorrem no Brasil. Não se observaram machos nas amostras.

\section{Família Heteroderidae}

Detectou-se Meloidogyne apenas em nove amostras, ou seja, 6,7 \% do total (Tabelas 4 e 8). Não se detectou Meloidogyne no solo remanescente das amostras por meio de bio-ensaio, exceção onde o nematóide havia sido detectado nas raízes. Três espécies estavam envolvidas: M. hapla em amoreira-preta (Campos do Jordão); $M$. incognita raça 1 em oliveira (São Bento do Sapucaí), pessegueiro (Atibaia e Guapiara) e mudas de caquizeiro [oriundas do Estado do Rio Grande do Sul e destinadas a transplantio em Guararema] e raça 2 em marmeleiro (Itaberá) e pessegueiro (Brotas); e M. javanica em pessegueiro (Guapiara e Itaberá). Apenas em Itaberá, M. javanica apareceu isoladamente; em Guapiara, coexistia com M. incognita. Os assinalamentos de M. incognita em oliveira e marmeleiro são novos para a literatura nacional. O nível populacional mais alto encontrado para esse gênero foi 12080 juvenis de segundo estádio de $M$. incognita raça 1 e $M$. javanica por $250 \mathrm{~cm}^{3}$ de solo em Guapiara. Todos os padrões da região perineal obtidos nas montagens seguiram os apresentados por Taylor \& Sasser (1978). 
Tabela 8. Espécies e raças de nematóides de galhas, Meloidogyne detectadas em fruteiras no Estado de São Paulo.

\begin{tabular}{cccc}
\hline Cultura & Local & Espécie & Raça \\
\hline Amoreira-preta & 2 & M. hapla & \\
Caquizeiro & 40 & M. incognita & 1 \\
Marmeleiro & 26 & M. incognita & 2 \\
Oliveira & 27 & M. incognita & 1 \\
Pessegueiro & $16-2$ & M. incognita & 2 \\
& $22-2$ & M. incognita e & 1 \\
& $23-1$ & M. javanica & 1 \\
& $25-2$ & M. incognita e & 2 \\
& 26 & M. incognitita & \\
& $31-3$ & M. javanica & \\
& & M. inconica & 1 \\
\hline
\end{tabular}

\section{Família Hoplolaimidae}

Dentro da família Hoplolaimidae, no gênero Helicotylenchus, H. dihystera consolidou-se como a espécie mais comum, sendo detectada em 49,0\% das amostras, não ocorrendo apenas em associação com framboeseira (Tabelas 4 e 9). O nível populacional mais elevado desse parasito foi de 2000 espécimes por $250 \mathrm{~cm}^{3}$ de solo em pessegueiro no município de Paranapanema. Os intervalos de variação dos valores morfométricos observados foram: $\mathrm{L}=622$ a $755 \mu \mathrm{m} ; \mathrm{a}=25,0$ a 33,3; b' $=4,6$ a 5,7; c $=$ 40,1 a 54,$0 ; c^{\prime}=0,9$ a 1,$3 ; \mathrm{o}=41,5$ a 50,0 ; st $=23,5$ a $25,0 \mu \mathrm{m}$; e $\mathrm{V}=57$ a $68 \%$. Tais resultados encontram-se de acordo com os citados por Sher (1966) e por outros autores no Brasil (Mendonça, 1976; Monteiro \& Lordello, 1976; Sperandio, 1992). Três outras espécies apareceram em algumas poucas amostras: H. erythrinae (Zimmermann, 1904) Golden, 1956 em nespereira em Monte Alegre do Sul; H. microcephalus Sher, 1966, em marmeleiro no município de São Roque (coexistindo com H. dihystera) e em macieira em Atibaia; e H. pseudorobustus (Steiner, 1914) Golden, 1956, em pessegueiro, em Guapiara (Tabela 10). 
Tabela 9. Valores morfométricos de fêmeas de Helicotylenchus dihystera obtidos a partir de espécimes coletados em fruteiras de clima subtropical e temperado*.

\begin{tabular}{|c|c|c|c|c|c|c|c|c|c|c|}
\hline Cultura & Local & $\mathbf{n}$ & $\mathbf{L}$ & $\mathbf{a}$ & b' & c & c' & o & st & $\mathbf{V}$ \\
\hline Amoreira & 1 & 3 & 678,3 & 30,8 & 5,1 & 47,4 & 1,2 & 44,7 & 25,3 & 63 \\
\hline Amoreira & 2 & 3 & 701,7 & 32,9 & 5,1 & 49,1 & 1,2 & 43,5 & 26 & 63 \\
\hline Amoreira & 4 & 4 & 698,8 & 28,8 & 5,2 & 48,2 & 1,2 & 44,9 & 26,3 & 62 \\
\hline Caquizeiro & 2 & 3 & 703,3 & 28,9 & 5,2 & 51,3 & 1,1 & 43,5 & 26 & 62 \\
\hline Caquizeiro & 5 & 5 & 695,6 & 28,3 & 5,2 & 49,7 & 1,2 & 47,9 & 24,2 & 61 \\
\hline Caquizeiro & 14 & 5 & 645,2 & 26,0 & 4,9 & 42,4 & 1,0 & 45,7 & 25,8 & 63 \\
\hline Caquizeiro & 18 & 2 & 663,0 & 29,3 & 5,2 & 42,2 & 1,0 & 45,6 & 26,3 & 59 \\
\hline Caquizeiro & 22 & 4 & 669,8 & 29,4 & 5,0 & 42,4 & 0,9 & 44,5 & 26,5 & 61 \\
\hline Caquizeiro & $26-2$ & 3 & 647,7 & 25,0 & 4,9 & 43,2 & 1,0 & 44,5 & 26,3 & 63 \\
\hline Caquizeiro & $27-2$ & 1 & 700 & 29,2 & 5,3 & 43,8 & 1,0 & 44,4 & 27 & 58 \\
\hline Caquizeiro & $30-1$ & 2 & 684 & 27,9 & 5,1 & 42,8 & 1,2 & 46,2 & 26 & 60 \\
\hline Caquizeiro & $30-2$ & 1 & 708 & 29,5 & 5,1 & 44,3 & 1,1 & 44,4 & 27 & 57 \\
\hline Macieira & $5-1$ & 4 & 691,3 & 28,4 & 5,0 & 49,4 & 1,1 & 43,7 & 26,3 & 63 \\
\hline Macieira & $5-2$ & 4 & 621,8 & 26,1 & 4,6 & 42,0 & 1,0 & 44,7 & 25,3 & 65 \\
\hline Macieira & $5-3$ & 3 & 681 & 32 & 5,3 & 48,6 & 1,0 & 43,5 & 26 & 61 \\
\hline Macieira & $5-4$ & 2 & 688,0 & 32 & 5,4 & 41,7 & 1,1 & 47,1 & 25,5 & 60 \\
\hline Macieira & 14 & 4 & 655,5 & 30,1 & 5,0 & 42,3 & 1,0 & 44,9 & 26,3 & 63 \\
\hline Macieira & 15 & 3 & 663,0 & 29,3 & 5,2 & 42,2 & 1,0 & 45,6 & 26,3 & 61 \\
\hline Macieira & 22 & 1 & 670 & 30,5 & 5,2 & 41,9 & 0,9 & 42,3 & 26,0 & 61 \\
\hline Macieira & 26 & 3 & 661,3 & 28,4 & 5,1 & 43,2 & 0,9 & 42,3 & 26,7 & 61 \\
\hline Nog. mac. & 17 & 3 & 705 & 33,1 & 5,2 & 42,2 & 1,0 & 45,6 & 26,3 & 59 \\
\hline Nog. mac. & 27 & 3 & 700 & 26,4 & 5,3 & 44,6 & 1,0 & 42,3 & 26,7 & 59 \\
\hline Marmeleiro & 1 & 3 & 695 & 27,5 & 5,1 & 49,6 & 1,2 & 44,1 & 26,3 & 63 \\
\hline Marmeleiro & 20 & 2 & 697,5 & 27,4 & 5,3 & 41,0 & 1,3 & 46,2 & 26 & 68 \\
\hline Marmeleiro & 27 & 4 & 665,0 & 28,3 & 5,0 & 43,5 & 1,0 & 45,3 & 26 & 62 \\
\hline Marmeleiro & 42 & 3 & 675,0 & 28,6 & 5,1 & 44,1 & 0,9 & 42,9 & 26,3 & 61 \\
\hline Nespereira & 15 & 2 & 627,5 & 27,9 & 4,7 & 40,5 & 1,0 & 43,3 & 26,5 & 64 \\
\hline Nespereira & $30-2$ & 4 & 678,0 & 29,7 & 5,4 & 42,4 & 0,9 & 45,4 & 26,0 & 60 \\
\hline Oliveira & 27 & 2 & 690,5 & 26,1 & 5,3 & 44,5 & 0,9 & 44,0 & 26,0 & 58 \\
\hline Pereira & 2 & 3 & 718,7 & 32,7 & 5,3 & 47,9 & 1,3 & 45,6 & 26,3 & 57 \\
\hline Pereira & 14 & 4 & 652,8 & 26,6 & 5,1 & 43,5 & 0,9 & 44,7 & 25,3 & 63 \\
\hline Pereira & 22 & 1 & 681 & 25,2 & 5,2 & 45,4 & 1,0 & 44,4 & 27 & 66 \\
\hline Pereira & 30 & 1 & 667,0 & 30,3 & 5,1 & 41,7 & 1,0 & 44,4 & 27 & 61 \\
\hline Pereira & 35 & 5 & 664,2 & 25,5 & 5,0 & 42,5 & 1,0 & 44,4 & 25,2 & 62 \\
\hline Pereira & 43 & 2 & 682,5 & 25,8 & 5,0 & 42,7 & 1,2 & 45,3 & 26,5 & 66 \\
\hline Pessegueiro & $1-1$ & 3 & 696,7 & 32,1 & 5,2 & 47,4 & 1,2 & 46,4 & 25,2 & 62 \\
\hline Pessegueiro & $2-1$ & 2 & 635 & 25,9 & 4,9 & 48,8 & 1,1 & 44,0 & 25 & 67 \\
\hline Pessegueiro & $2-2$ & 1 & 700 & 33,3 & 5,1 & 53,8 & 1,1 & 44,4 & 27 & 64 \\
\hline Pessegueiro & $5-1$ & 4 & 653,3 & 26,3 & 4,7 & 45,1 & 1,1 & 48,6 & 24,3 & 65 \\
\hline Pessegueiro & $5-2$ & 2 & 658,5 & 31,4 & 4,9 & 43,9 & 1,1 & 48,9 & 23,5 & 63 \\
\hline Pessegueiro & 6 & 4 & 656,3 & 26,8 & 4,8 & 45,9 & 1,1 & 48,3 & 23,8 & 63 \\
\hline Pessegueiro & 7 & 4 & 679,5 & 27,2 & 4,9 & 46,9 & 0,9 & 43,8 & 25,8 & 61 \\
\hline Pessegueiro & $8-3$ & 3 & 670 & 30,9 & 5,2 & 46,9 & 0,9 & 44,5 & 26,3 & 62 \\
\hline Pessegueiro & $8-5$ & 4 & 643,8 & 28,0 & 4,9 & 42,1 & 1,0 & 45,7 & 25,8 & 64 \\
\hline Pessegueiro & $8-6$ & 6 & 667,5 & 30,8 & 5,2 & 45,4 & 0,9 & 45,0 & 26 & 61 \\
\hline
\end{tabular}


Tabela 9. Valores morfométricos de fêmeas de Helicotylenchus dihystera obtidos a partir de espécimes coletados em fruteiras de clima subtropical e temperado*.

\begin{tabular}{ccccccccccc}
\hline Cultura & Local & $\mathbf{n}$ & $\mathbf{L}$ & $\mathbf{a}$ & $\mathbf{b}$ & $\mathbf{c}$ & $\mathbf{c}^{\prime}$ & $\mathbf{0}$ & $\mathbf{s t}$ & $\mathbf{V}$ \\
\hline Pessegueiro & $9-1$ & 3 & 682,7 & 31,5 & 5,2 & 49,8 & 1,0 & 47,4 & 25,3 & 59 \\
Pessegueiro & $9-2$ & 4 & 657 & 30 & 5,3 & 42,9 & 1,0 & 44,2 & 26 & 63 \\
Pessegueiro & 11 & 2 & 673,5 & 31,3 & 5,3 & 49,9 & 0,9 & 42,6 & 27,0 & 61 \\
Pessegueiro & 12 & 3 & 688,7 & 26,2 & 5,2 & 49,2 & 1,0 & 42,3 & 26,7 & 61 \\
Pessegueiro & 13 & 4 & 685,5 & 26,9 & 5,1 & 48,9 & 1,1 & 42,3 & 26,3 & 60 \\
Pessegueiro & $18-1$ & 3 & 643,3 & 25,4 & 5,1 & 42,0 & 0,9 & 41,8 & 26,3 & 64 \\
Pessegueiro & $18-2$ & 2 & 653 & 30,4 & 5,2 & 43,5 & 0,9 & 42,3 & 26 & 62 \\
Pessegueiro & 19 & 2 & 655,5 & 30,5 & 5,0 & 43,7 & 1,0 & 46,2 & 26 & 63 \\
Pessegueiro & $22-1$ & 4 & 678,0 & 29,7 & 5,4 & 42,4 & 0,9 & 45,4 & 26,0 & 60 \\
Pessegueiro & $22-2$ & 3 & 642,3 & 25,4 & 5,3 & 40,1 & 1,0 & 45,5 & 25,7 & 64 \\
Pessegueiro & $22-3$ & 2 & 704 & 31,3 & 5,5 & 44 & 0,9 & 45,3 & 26,5 & 58 \\
Pessegueiro & $22-4$ & 5 & 662,8 & 29,6 & 5,0 & 43,6 & 0,9 & 44,4 & 26,6 & 64 \\
Pessegueiro & $23-1$ & 2 & 672 & 26,9 & 5,1 & 42,0 & 1,0 & 45,3 & 26,5 & 61 \\
Pessegueiro & $23-2$ & 2 & 649,5 & 28,9 & 5,1 & 41,9 & 0,9 & 41,5 & 26,5 & 63 \\
Pessegueiro & 24 & 3 & 654,3 & 30,7 & 5,3 & 43,6 & 0,9 & 44,5 & 26,3 & 62 \\
Pessegueiro & 26 & 2 & 627,5 & 27,9 & 4,7 & 40,5 & 1,0 & 43,3 & 26,5 & 64 \\
Pessegueiro & 27 & 3 & 678,0 & 30,4 & 5,4 & 45,2 & 1,0 & 43,3 & 27,0 & 62 \\
Pessegueiro & $31-3$ & 2 & 682 & 27,8 & 5,2 & 45,4 & 1,0 & 43,4 & 26,5 & 60 \\
Pessegueiro & $32-1$ & 1 & 708 & 29,5 & 5,1 & 44,3 & 1,1 & 44,4 & 27 & 57 \\
Pessegueiro & 33 & 4 & 701 & 26,5 & 5,4 & 45,2 & 1,0 & 44,5 & 26,5 & 59 \\
Pessegueiro & 44 & 2 & 688,5 & 29,9 & 5,1 & 44,4 & 1,3 & 50,0 & 25 & 61 \\
Pessegueiro & 45 & 3 & 709,3 & 31,2 & 5,2 & 45,2 & 1,1 & 47,6 & 26,7 & 60 \\
Pessegueiro & 47 & 4 & 755,0 & 28,1 & 5,7 & 45,7 & 1,1 & 48,0 & 25 & 60 \\
Pessegueiro & 49 & 1 & 731 & 28,1 & 5,7 & 45,7 & 1,1 & 48,0 & 25 & 60 \\
Pessegueiro & 51 & 2 & 697,5 & 27,4 & 5,3 & 41,0 & 1,3 & 46,2 & 26 & 68 \\
Umezeiro & $2-2$ & 3 & 690,3 & 31,0 & 5,3 & 44,0 & 1,0 & 45,6 & 26,3 & 58 \\
Umezeiro & 12 & 2 & 702,5 & 31,2 & 5,5 & 54,0 & 0,9 & 46,1 & 26 & 60 \\
Umezeiro & 20 & 3 & 676,3 & 30,3 & 5,3 & 43,1 & 0,9 & 43,4 & 25,3 & 60 \\
\hline
\end{tabular}

*: "L" e "st" expressos em micrômetros; "V" e "o" expressos em valores percentuais.

Não se observaram machos nas amostras. As conformações da região labial, do estilete e da cauda, a forma assumida pelo exemplar quando morto pelo calor, a junção da linhas internas dos campos laterais e a presença ou não de machos (espermateca cheia ou vazia) são alguns dos caracteres diagnósticos para a identificação específica dentro do gênero. Em alguns casos, não foi possível a identificação ao nível de espécie porque as amostras continham somente juvenis ou muito poucos exemplares adultos, nos quais parte dos caracteres não estava bem visível. 
Tabela 10. Valores morfométricos de fêmeas e machos de Hoplolaimidae obtidos a partir de espécimes coletados em fruteiras de clima subtropical e temperado*.

\begin{tabular}{|c|c|c|c|c|c|c|c|c|c|c|}
\hline \multicolumn{11}{|c|}{ Aorolaimus nigeriensis (Fêmeas) } \\
\hline Cultura & Local & $\mathbf{n}$ & $\mathbf{L}$ & $\mathbf{a}$ & b' & c & $\mathbf{c}^{\prime}$ & $\mathbf{0}$ & st & V \\
\hline Macieira & 22 & 4 & 836,0 & 26,7 & 5,5 & 52,9 & 0,7 & - & 29,5 & 57,9 \\
\hline Pessegueiro & $25-1$ & 3 & 831,0 & 27,4 & 5,9 & 46,2 & 0,8 & - & 29,6 & 54,0 \\
\hline Pessegueiro & $25-2$ & 2 & 811,0 & 31,8 & 6,8 & 62,4 & 0,8 & - & 29,5 & 56,0 \\
\hline \multicolumn{11}{|c|}{ A. nigeriensis (Machos) } \\
\hline Cultura & Local & $\mathbf{n}$ & $\mathbf{L}$ & $\mathbf{a}$ & b' & c & c' & o & st & Esp \\
\hline Macieira & 22 & 3 & 714,0 & 27,1 & 4,9 & 48,6 & 1,4 & - & 29,3 & 32,7 \\
\hline Pessegueiro & $25-1$ & 3 & 689,0 & 33,2 & 5,8 & 58,9 & 1,1 & - & 29,7 & 33,0 \\
\hline Pessegueiro & $25-2$ & 2 & 718,5 & 32,7 & 5,8 & 53,2 & 1,2 & - & 29,0 & 32,0 \\
\hline \multicolumn{11}{|c|}{ Helicotylenchus erythrinae (Fêmeas) } \\
\hline Cultura & Local & $\mathbf{n}$ & $\mathbf{L}$ & $\mathbf{a}$ & b' & c & c' & o & st & V \\
\hline Nespereira & 14 & 1 & 582,0 & 27,7 & 4,5 & 29,1 & 1,1 & 37,5 & 24,0 & 61,9 \\
\hline \multicolumn{11}{|c|}{ Helicotylenchus microcephalus (Fêmeas) } \\
\hline Cultura & Local & $\mathbf{n}$ & $\mathbf{L}$ & $\mathbf{a}$ & b' & c & c' & $\mathbf{o}$ & st & $\mathbf{V}$ \\
\hline Marmeleiro & 20 & 1 & 560,0 & 29,4 & 4,2 & 29,5 & 1,5 & 40,7 & 27,0 & 63,0 \\
\hline Macieira & 30 & 1 & 610,0 & 29,0 & 4,7 & 33,9 & 1,3 & 38,0 & 26,0 & 64,9 \\
\hline \multicolumn{11}{|c|}{ Helicotylenchus pseudorobustus (Fêmeas) } \\
\hline Cultura & Local & $\mathbf{n}$ & $\mathbf{L}$ & $\mathbf{a}$ & b' & c & c' & $\mathbf{0}$ & st & $\mathbf{V}$ \\
\hline Pessegueiro & $22-1$ & 1 & 718,0 & 28,7 & 5,2 & 37,8 & 1,1 & 40,7 & 27,0 & 60,0 \\
\hline \multicolumn{11}{|c|}{ Rotylenchulus reniformis (Fêmeas imaturas) } \\
\hline Cultura & Local & $\mathbf{n}$ & $\mathbf{L}$ & $\mathbf{a}$ & b' & c & c' & $\mathbf{o}$ & st & $\mathbf{V}$ \\
\hline Marmeleiro & 21 & 4 & 363,3 & 16,7 & 3,7 & 15,3 & - & - & 16,8 & 72,0 \\
\hline Pessegueiro & $25-1$ & 2 & 350,5 & 15,6 & 3,7 & 14,6 & - & - & 17 & 75,7 \\
\hline \multicolumn{11}{|c|}{ Rotylenchulus reniformis (Machos) } \\
\hline Cultura & Local & $\mathbf{n}$ & $\mathbf{L}$ & $\mathbf{a}$ & $b^{\prime}$ & c & c' & $\mathbf{o}$ & st & Esp \\
\hline Marmeleiro & 21 & 1 & 410 & 27,3 & - & 16,4 & - & - & 13 & 22 \\
\hline Pessegueiro & $25-1$ & 1 & 394 & 24,6 & - & 15,8 & - & - & 13 & 23 \\
\hline \multicolumn{11}{|c|}{ Scutellonema brachyurus (Fêmeas) } \\
\hline Cultura & Local & $\mathbf{n}$ & $\mathbf{L}$ & $\mathbf{a}$ & b' & c & $c^{\prime}$ & $\mathbf{0}$ & st & $\mathbf{V}$ \\
\hline Amoreira & 1 & 4 & 806,0 & 27,5 & 5,4 & 91,6 & 0,6 & - & 27,5 & 58,7 \\
\hline Caquizeiro & 18 & 2 & 803,0 & 28,2 & 5,4 & 89,2 & 0,6 & - & 27 & 58,7 \\
\hline Pessegueiro & 19 & 3 & 765,3 & 25,3 & 6,1 & 56,3 & 0,8 & - & 29 & 60,1 \\
\hline Pessegueiro & 43 & 4 & 734,5 & 24,5 & 5,5 & 52,5 & 0,8 & - & 29 & 57,9 \\
\hline
\end{tabular}

*: "L", "st" e "Esp." expressos em micrômetros; "V" e "o" expressos em valores percentuais. 
Dessa forma, em quatorze amostras $(9,4 \%)$ as populações foram identificadas como Helicotylenchus spp. Outros Hoplolaimidae encontrados foram Aorolaimus nigeriensis (Sher, 1964) Fortuner, 1987 em macieira e pessegueiro em Guapiara, Rotylenchulus reniformis em marmeleiro (Limeira) e pessegueiro (Guapiara) e Scutellonema brachyurus (Steiner, 1938) Andrássy, 1958 em amoreira-preta (Campos do Jordão), caquizeiro (Mairinque) e pessegueiro (Mairinque e Jundiaí) (Tabela 10). Essas ocorrências são novas para a literatura nacional.

Todas as características da espécie $A$. nigeriensis estão em conformidade com as citadas por Sher (1964), à exceção do comprimento do corpo que, nas populações de macieira e pessegueiro (Guapiara), estão acima dos valores estabelecidos por esse autor, porém dentro da faixa encontrada por Bittencourt \& Huang (1986) e Rashid et al. (1987) (Tabela 10). Os principais caracteres diagnósticos observados nessa espécie foram a ausência de linhas transversais nas proximidades dos fasmídios, presença de epiptigma duplo e bem desenvolvido, presença de machos e cauda com menos de doze anéis, sendo os distais mais largos que os demais. Nas populações estudadas, os espécimes tinham duas ou quatro linhas no campo lateral na região intermediária do corpo, característica também observada por Bittencourt \& Huang (1986).

As fêmeas vermiformes, sexualmente imaturas, e os machos de Rotylenchulus reniformis, espécie cosmopolita conhecida como nematóide reniforme, obtidas de amostras de solo, apresentaram valores morfométricos de acordo com os citados por Siddiqi (1972).

Os valores biométricos obtidos para a espécie Scutellonema brachyurus estão em concordância com os de Sher (1963) e Germani et al. (1985), exceto para "c", que se mostrou ligeiramente inferior aos apresentados por tais autores (52,5 vs. 55,4 ou 56). À exceção da amostra coletada em pessegueiro (Jundiaí), em todas as demais Scutellonema brachyurus ocorreu conjuntamente com $H$. dihystera. 


\section{Família Longidoridae}

Cinco espécies de Xiphinema foram identificadas: X. brevicollum associada a pessegueiro (Campos do Jordão, Paranapanema, Mairinque e Atibaia), macieira (Paranapanema e Itaberá), nogueira-macadâmia (Tietê), caquizeiro (Mairinque) e nespereira (Itaberá e São Bento do Sapucaí); X. elongatum em amoreira-preta (Santo Antônio do Pinhal), umezeiro (São Roque) e macieira (Itaberá); X. krugi em pessegueiro (Atibaia, Campos do Jordão, Monte Alegre do Sul e Paranapanema), caquizeiro (Campos do Jordão), macieira (Campos do Jordão e Monte Alegre do Sul), nespereira (Monte Alegre do Sul), marmeleiro (São Bento do Sapucaí) e umezeiro (São Roque); X. setariae somente em marmeleiro (São Roque e São Bento do Sapucaí); e X. surinamense em pessegueiro, macieira, caquizeiro e pereira em Guapiara e marmeleiro em São Bento do Sapucaí (Tabela 11). Excetuando X. brevicollum em pessegueiro, X. krugi em nespereira e pessegueiro e $X$. surinamense em marmeleiro, todas as demais são novas ocorrências nessas fruteiras no Brasil. Os valores mensurados encontram-se na Tabela 11. Esses resultados estão de acordo com os de Lordello \& Costa (1961), Loof \& Maas (1972), Luc \& Hunt (1978), Ferraz, L. (1980) e Loof \& Luc (1990). Alguns valores encontram-se pouco abaixo da faixa de variação apresentada pelos citados autores. Em relação ao trabalho de Lordello \& Costa (1961), observaram-se as seguintes diferenças: as populações de $X$. brevicollum de nogueira-macadâmia e caquizeiro (L=1785 e 1793 vs. $1818 \mu \mathrm{m}$ : valor mínimo), "a” de nogueira-macadâmia (35,7 vs. 36,0), "b” de caquizeiro, macieira (Itaberá), nespereira (São Bento do Sapucaí) e pessegueiro (Atibaia) (6,0 a 6,7 vs. 7,0), comprimento do estilete de pessegueiro (Paranapanema), nogueira-macadâmia e caquizeiro (148 a 152 vs. $156 \mu \mathrm{m})$. No caso de $X$. setariae, os exemplares mensurados das populações de nog. macadâmia e marmeleiro tinham o comprimento do corpo pouco abaixo da caracterização apresentada por Loof \& Maas (1972) (2 294 e 2165 vs. 2 $380 \mu \mathrm{m}$ ), além dos valores "a" de nog. macadâmia (47,8 vs. 49), "c" de marmeleiro (São Bento do Sapucaí) (47,1 vs. 48), V das duas populações oriundas de marmeleiro (37,1 e $37,3$ vs. $38,0 \%)$. 
Tabela 11. Valores morfométricos de fêmeas de Xiphinema obtidos a partir de mensuração feita em espécimes coletados em fruteiras de clima subtropical e temperado*.

\begin{tabular}{|c|c|c|c|c|c|c|c|c|c|c|}
\hline \multirow[b]{2}{*}{ Cultura } & \multicolumn{10}{|c|}{ Xiphinema brevicollum } \\
\hline & Local & $\mathbf{n}$ & $\mathbf{L}$ & $\mathbf{a}$ & $\mathbf{b}$ & c & $\mathbf{c}^{\prime}$ & $\mathbf{V}$ & st & cd \\
\hline Caquizeiro & 18 & 1 & 1793,0 & 38,1 & 6,4 & 66,4 & 0,9 & 53,0 & 148,0 & 27,0 \\
\hline Macieira & $5-3$ & 1 & 2131,0 & 40,2 & 7,1 & 73,5 & 0,9 & 52,1 & 163,0 & 29,0 \\
\hline Macieira & 26 & 1 & 2011,0 & 35,9 & 6,0 & 74,5 & 0,8 & 54,0 & 158,0 & 27,0 \\
\hline Nog. mac. & 17 & 1 & 1785,0 & 35,7 & 8,6 & 68,7 & 0,9 & 53,0 & 149,0 & 26,0 \\
\hline Nespereira & 26 & 2 & 1926,5 & 36,3 & 7,0 & 68,8 & 0,9 & 51,0 & 160,0 & 28,0 \\
\hline Nespereira & 27 & 2 & 1933,5 & 38,7 & 6,3 & 69,1 & 0,9 & 54,0 & 165,0 & 28,0 \\
\hline Pessegueiro & $1-2$ & 1 & 1947,0 & 38,2 & 9,0 & 72,1 & 0,9 & 53,0 & 161,0 & 27,0 \\
\hline Pessegueiro & $8-3$ & 3 & 1941,7 & 38,1 & 8,9 & 71,1 & 0,9 & 54,0 & 152,7 & 27,3 \\
\hline Pessegueiro & 19 & 2 & 1994,0 & 39,5 & 7,2 & 72,5 & 0,9 & 54,1 & 157,5 & 27,5 \\
\hline \multirow[t]{2}{*}{ Pessegueiro } & $30-3$ & 1 & 2005,0 & 38,6 & 6,7 & 69,1 & 0,9 & 50,0 & 164,0 & 29,0 \\
\hline & \multicolumn{10}{|c|}{ Xiphinema elongatum } \\
\hline Amoreira & 4 & 1 & 2170,0 & 55,6 & 6,1 & 37,4 & 2,2 & 40,0 & 153,0 & 58,0 \\
\hline Macieira & 26 & 1 & 2249,0 & 51,1 & 6,1 & 38,1 & 2,5 & 40,8 & 152,0 & 59,0 \\
\hline \multirow[t]{2}{*}{ Umezeiro } & 20 & 3 & 2330,0 & 55,9 & 6,0 & 40,7 & 2,3 & 39,6 & 155,5 & 57,3 \\
\hline & \multicolumn{10}{|c|}{ Xiphinema krugi } \\
\hline Caquizeiro & 2 & 1 & 2010,0 & 34,1 & 5,8 & 49,0 & 1,2 & 31,0 & 168,0 & 41,0 \\
\hline Macieira & 2 & 1 & 1712,0 & 34,2 & 5,3 & 47,6 & 1,3 & 33,1 & 172,0 & 36,0 \\
\hline Macieira & 14 & 1 & 1697,0 & 34,6 & 4,7 & 40,4 & 1,2 & 36,9 & 171,0 & 42,0 \\
\hline Marmeleiro & 27 & 1 & 1942,0 & 40,5 & 5,4 & 48,6 & 1,3 & 33,4 & 177,0 & 40,0 \\
\hline Nespereira & 14 & 2 & 1813,0 & 35,9 & 5,1 & 43,7 & 1,2 & 35,8 & 174,0 & 41,5 \\
\hline Pessegueiro & $1-2$ & 2 & 1890,0 & 39,8 & 5,4 & 47,8 & 1,2 & 32,9 & 173,0 & 39,5 \\
\hline Pessegueiro & $8-3$ & 2 & 1809,0 & 35,8 & 5,1 & 44,1 & 1,3 & 35,0 & 177,0 & 41,0 \\
\hline Pessegueiro & $10-1$ & 1 & 2010,0 & 39,4 & 5,4 & 49,0 & 1,2 & 33,0 & 179,0 & 41,0 \\
\hline Pessegueiro & 14 & 1 & 1897,0 & 37,2 & 5,3 & 46,3 & 1,3 & 33,8 & 176,0 & 41,0 \\
\hline Pessegueiro & $32-2$ & 2 & 1851,0 & 37,8 & 5,2 & 45,7 & 1,1 & 34,9 & 170,5 & 40,5 \\
\hline \multirow[t]{2}{*}{ Umezeiro } & 20 & 1 & 1814,0 & 36,3 & 5,2 & 45,4 & 1,1 & 35,9 & 169,0 & 40,0 \\
\hline & \multicolumn{10}{|c|}{ Xiphinema setariae } \\
\hline Nog. mac. & 26 & 1 & 2294,0 & 47,8 & 8,1 & 62,0 & 1,6 & 38,0 & 182,0 & 37,0 \\
\hline Marmeleiro & 20 & 1 & 2437,0 & 54,2 & 6,9 & 50,8 & 1,5 & 37,1 & 184,0 & 48,0 \\
\hline \multirow[t]{2}{*}{ Marmeleiro } & 27 & 1 & 2165,0 & 49,2 & 6,1 & 47,1 & 1,5 & 37,3 & 179,0 & 46,0 \\
\hline & \multicolumn{10}{|c|}{ Xiphinema surinamense } \\
\hline Caquizeiro & 22 & 1 & 2341,0 & 43,4 & 5,1 & 86,7 & 0,8 & 39,0 & 187,0 & 27,0 \\
\hline Macieira & 22 & 1 & 2112,0 & 43,1 & 5,1 & 81,2 & 0,8 & 37,3 & 189,0 & 26,0 \\
\hline Marmeleiro & 27 & 1 & 2183,0 & 42,8 & 5,0 & 84,0 & 0,8 & 36,3 & 191,0 & 26,0 \\
\hline Pereira & 22 & 1 & 2098,0 & 41,1 & 5,3 & 77,7 & 0,8 & 38,3 & 189,0 & 27,0 \\
\hline Pessegueiro & $22-1$ & 1 & 2034,0 & 42,4 & 5,2 & 78,2 & 0,8 & 36,7 & 188,0 & 26,0 \\
\hline Pessegueiro & $22-4$ & 1 & 2334,0 & 44,0 & 5,2 & 80,5 & 0,8 & 37,5 & 191,0 & 29,0 \\
\hline
\end{tabular}

*: "L", "st" e "cd." expressos em micrômetros; "V" expresso em valor percentual. 
Entretanto, houve concordância com os resultados de Ferraz, L. (1980), que observou valores ainda inferiores aos ora obtidos. Em relação a $X$. surinamense, os resultados do comprimento do corpo contrastaram com os de Loof \& Maas (1972); assim, em todos os exemplares aqui mensurados, o valor "L" ficou abaixo da faixa estabelecida na descrição original da espécie por esses autores (2 034 a 2334 vs. $2400 \mu \mathrm{m}$ ). Todavia, Ferraz, L. (1980) também encontrou valores inferiores aos citados na descrição original. Além disso, segundo a chave taxionômica apresentada por Loof \& Luc (1990), a faixa de comprimento do corpo apresentada para essa espécie é bem ampla, variando de 1500 a 4 $400 \mu \mathrm{m}$ entre as muitas populações já estudadas, procedentes de diferentes áreas geográficas. Não se observou a presença de machos nas populações amostradas; tal fato, embora curioso para uma espécie tida como anfimítica, também tem sido verificado em muitas outras populações estudadas. Determinou-se a presença de Xiphinema spp. em 18 amostras por apresentarem somente juvenis ou poucos adultos, nos quais não foi possível a plena visualização dos caracteres diagnósticos. Nas fêmeas, esses caracteres são o comprimento do estilete, a organização do sistema reprodutor, a posição relativa da vulva e a forma das regiões labial e caudal.

\section{Família Pratylenchidae}

Verificou-se a presença de Pratylenchus brachyurus e P. zeae apenas em caquizeiros (Mairinque) e nespereira (Monte Alegre do Sul) (Tabelas 04 e 05). Os valores morfométricos obtidos foram: P. brachyurus: (caquizeiro) $\mathrm{n}=3 ; \mathrm{L}=511 \mu \mathrm{m} ; \mathrm{a}=$ 24,$7 ; b^{\prime}=3,2 ; c=15,0 ; V=85 \%$; st $=19 \mu \mathrm{m}$; (nespereira) $\mathrm{L}=510 \mu \mathrm{m} ; \mathrm{a}=24,3 ; \mathrm{b}^{\prime}=$ 3,$4 ; \mathrm{c}=15,9 ; \mathrm{V}=85 \%$; $\mathrm{st}=18,7 \mu \mathrm{m} ;$ P. zeae: (caquizeiro): $\mathrm{n}=2 ; \mathrm{L}=449 \mu \mathrm{m} ; \mathrm{a}=23,6$; $\mathrm{c}=16,0 ; \mathrm{V}=72 \% ; \mathrm{st}=15,3 \mu \mathrm{m} ;($ nespereira) $: \mathrm{n}=3 ; \mathrm{L}=530,0 ; \mathrm{a}=27,5 ; \mathrm{c}=17,7 ; \mathrm{V}=$ 69,7 ; st $=15,3 \mu \mathrm{m}$. Esses valores estão em concordância com os de Roman \& Hirschmann (1969) e Sperandio (1992), exceto para "L" de P. zeae (caquizeiro) (449 vs. $463 \mu \mathrm{m}$ : valor mínimo, segundo Roman \& Hirschmann, 1969) e “a” (23,6 vs. 24,6: valor mínimo, Sperandio, 1992). Características diagnósticas como número de anéis labiais, 
morfologia dos bulbos do estilete, ausência de machos, posição relativa da vulva e forma da cauda foram usadas na identificação específica.

\section{Família Tylenchulidae}

Tylenchulus semipenetrans foi detectado em pomares de caquizeiro e pereira em Campos de Jordão (Tabelas 4 e 5). Esta última referência constitui novo registro para o Brasil. De 29 amostras coletadas de caquizeiro, a espécie ocorreu em 15. O nível populacional mais alto foi de 14160 espécimes por $250 \mathrm{~cm}^{3}$ de solo, em Paranapanema (Tabela 4). A identificação específica baseou-se em caracteres morfológicos da fêmea madura e de juvenis e machos, que se mostraram plenamente concordantes com os descritos por Inserra et al. (1988).

\subsection{Capacidade reprodutiva dos nematóides de galhas nas fruteiras}

Todos os genótipos testados reagiram como resistentes a $M$. incognita raça 2 e $M$. javanica, à exceção de 'GF 677', considerado a priori como padrão de suscetibilidade (Tabelas 12 e 13). Nessa cultivar, obtiveram-se IG e IMO iguais a 5 e 2,7 para $M$. incognita e 5 e 3,3 para M. javanica, respectivamente. Tomateiros 'Rutgers' inoculados proporcionaram valores de IG e IMO iguais a 5, demonstrando a viabilidade dos inóculos empregados.

No experimento com $M$. incognita, não se encontraram galhas ou massas de ovos externas nas demais fruteiras. Entretanto, observaram-se reduzidos níveis de reprodução para certos genótipos, diferentes estatisticamente. Para NSR e NGR, 'GF 677' diferiu de todos os demais tratamentos, com taxa de crescimento populacional ( $\mathrm{Pf} / \mathrm{Pi})$ da ordem de até três vezes. Os seguintes genótipos tiveram valores decrescentes de NSR e NGR: Precoce de Campinas, Keauhou, Tsukuba-3, Mizuho, Okinawa, Ébano, Japão, Kumagai, G x N 22, G x N 9, Keaumi e Waialua. Nesses genótipos, as médias variaram de 206,1 a 21,3 (NSR) e 62,4 a 8,6 (NGR). Não se obtiveram nematóides nas demais fruteiras avaliadas. 
Semelhanças ocorreram no experimento com M. javanica, em que 'GF 677' reagiu como bom hospedeiro do nematóide e também se diferenciou estatisticamente dos demais genótipos. Verificaram-se galhas e massas de ovos em genótipos de diferentes fruteiras. Além de 'GF 677', todos os demais Prunus, exceto umezeiro, apresentaram galhas e massas de ovos, com os IG e IMO variando de 1,3 e 0,8 para ' $G$ x N 22' a 3,8 e 2,4 para 'Tsukuba 2'. O porta-enxerto tido como padrão de resistência, 'Okinawa', apresentou IG consideravelmente alto $(3,8)$, porém nenhuma massa de ovos foi encontrada nas raízes. Fato semelhante ocorreu com 'Boisenberry' e 'Arbequina', nas quais se verificaram galhas ocasionais ( $\mathrm{IG}=0,6$ e 0,4$)$, mas não apresentaram massas de ovos. Encontraram-se nematóides (NSR e NGR) em outros nove genótipos: 'G x N 15', 'Tsukuba 2', 'Tsukuba 1', 'Arbequina', 'Sassaoka', 'Boisenberry', 'Umê', 'Paluma' e 'Kakedo', além de 'GF 677' e dos citados no outro experimento. Os maiores valores de NSR e NGR foram 801,3 e 146,7 para 'G x N 9' e os menores 2,5 e 0,6 para 'Okinawa'. Nos demais genótipos não se encontraram nematóides após 120 dias da inoculação.

\subsection{Reação de caquizeiros aos nematóides de galhas}

Os sete genótipos reagiram como resistentes frente a ambas as espécies de nematóides (Tabelas 14 e 15). No experimento com M. incognita, 'Regina' foi o mais infestado de todos os genótipos avaliados. Observaram-se engrossamentos radiculares característicos causados por Meloidogyne, avaliados pelo parâmetro NI que, nesse caso, foi igual a 6,1. Diferenças estatísticas ocorreram entre as médias dos genótipos. Na cultivar Regina, obtiveram-se os maiores números de nematóides no sistema radicular $(\mathrm{NSR}=2275,6)$ e por grama de raízes $(\mathrm{NGR}=260,8)$, diferenciando-se dos demais genótipos (Tabela 14). 
Tabela 12. Índice de galhas (IG) e de massas de ovos (IMO), número de nematóides no sistema radicular (NSR) e por grama de raiz (NGR) e reação (R) de Meloidogyne incognita raça 2 em fruteiras de clima subtropical e temperado aos 120 dias após a inoculação de 5.000 ovos por planta em 0,5 litros de solo.

\begin{tabular}{|c|c|c|c|c|c|c|c|c|}
\hline Fruteiras & IG & IMO & $\mathrm{NSR}^{1}$ & & & $\overline{\text { NGR }^{1}}$ & & Reação $^{2}$ \\
\hline GF $677^{3}$ & 5 & 2,7 & $15.409,5$ & $\mathrm{a}$ & & 946,8 & $\mathrm{a}$ & $\bar{S}$ \\
\hline Precoce de Campinas & 0 & 0 & 206,1 & $\mathrm{~b}$ & & 62,4 & $\mathrm{~b}$ & $\mathrm{R}$ \\
\hline Keauhou & 0 & 0 & 190,0 & $\mathrm{~b}$ & & 43,3 & $\mathrm{bc}$ & $\mathrm{R}$ \\
\hline Tsukuba 3 & 0 & 0 & 189,6 & $\mathrm{~b}$ & & 23,8 & $\mathrm{bcd}$ & $\mathrm{R}$ \\
\hline Mizuho & 0 & 0 & 111,8 & $\mathrm{bc}$ & & 71,9 & $\mathrm{~b}$ & $\mathrm{R}$ \\
\hline Okinawa $^{4}$ & 0 & 0 & 82,5 & b c d & & 14,9 & $\mathrm{bc} \mathrm{de}$ & $\mathrm{R}$ \\
\hline Ébano & 0 & 0 & 57,3 & c d & $\mathrm{e}$ & 10,0 & $d e f$ & $\mathrm{R}$ \\
\hline Japão & 0 & 0 & 52,1 & d & $\mathrm{e}$ & 27,0 & $\mathrm{cdef}$ & $\mathrm{R}$ \\
\hline Kumagai & 0 & 0 & 49,1 & $\mathrm{bc} \mathrm{d}$ & $\mathrm{e}$ & 17,1 & $\mathrm{bcde}$ & $\mathrm{R}$ \\
\hline $\mathrm{G} \times \mathrm{N} 22$ & 0 & 0 & 39,8 & & e & 11,4 & de $f$ & $\mathrm{R}$ \\
\hline G x N 9 & 0 & 0 & 29,6 & $\mathrm{~d}$ & $\mathrm{e}$ & 7,0 & e f & $\mathrm{R}$ \\
\hline Keaumi & 0 & 0 & 27,6 & & e & 4,5 & $\mathrm{f} g$ & $\mathrm{R}$ \\
\hline Waialua & 0 & 0 & 21,3 & & $\mathrm{e}$ & 8,6 & $d$ e $f$ & $\mathrm{R}$ \\
\hline Gx N 15 & 0 & 0 & 0 & & $\mathrm{f}$ & 0 & $\mathrm{~g}$ & $\mathrm{R}$ \\
\hline Tsukuba 2 & 0 & 0 & 0 & & $\mathrm{f}$ & 0 & $\mathrm{~g}$ & $\mathrm{R}$ \\
\hline Tsukuba 1 & 0 & 0 & 0 & & $\mathrm{f}$ & 0 & $\mathrm{~g}$ & $\mathrm{R}$ \\
\hline Arbequina & 0 & 0 & 0 & & $\mathrm{f}$ & 0 & $\mathrm{~g}$ & $\mathrm{R}$ \\
\hline Sassaoka & 0 & 0 & 0 & & $\mathrm{f}$ & 0 & $\mathrm{~g}$ & $\mathrm{R}$ \\
\hline Boisenberry & 0 & 0 & 0 & & $\mathrm{f}$ & 0 & $\mathrm{~g}$ & $\mathrm{R}$ \\
\hline Umê & 0 & 0 & 0 & & $\mathrm{f}$ & 0 & $\mathrm{~g}$ & $\mathrm{R}$ \\
\hline Paluma & 0 & 0 & 0 & & $\mathrm{f}$ & 0 & $\mathrm{~g}$ & $\mathrm{R}$ \\
\hline Kakedo & 0 & 0 & 0 & & $\mathrm{f}$ & 0 & $\mathrm{~g}$ & $\mathrm{R}$ \\
\hline Parmogi & 0 & 0 & 0 & & $\mathrm{f}$ & 0 & $\mathrm{~g}$ & $\mathrm{R}$ \\
\hline Néctar de Cristal & 0 & 0 & 0 & & $\mathrm{f}$ & 0 & $\mathrm{~g}$ & $\mathrm{R}$ \\
\hline M 9 & 0 & 0 & 0 & & $\mathrm{f}$ & 0 & $\mathrm{~g}$ & $\mathrm{R}$ \\
\hline MM 106 & 0 & 0 & 0 & & $\mathrm{f}$ & 0 & $\mathrm{~g}$ & $\mathrm{R}$ \\
\hline Maruba & 0 & 0 & 0 & & $\mathrm{f}$ & 0 & $\mathrm{~g}$ & $\mathrm{R}$ \\
\hline Taiwan Nashi - C & 0 & 0 & 0 & & $\mathrm{f}$ & 0 & $\mathrm{~g}$ & $\mathrm{R}$ \\
\hline
\end{tabular}

${ }^{1}$ Médias originais seguidas da mesma letra, na coluna, não diferem entre si estatisticamente (Tukey 5\%) (dados transformados em $\log \mathrm{x}+1$ na análise)

${ }^{2} \mathrm{R}=$ resistência; $\mathrm{S}=$ suscetibilidade

${ }^{3}$ Referência de suscetibilidade

${ }^{4}$ Referência de resistência 
Tabela 13. Índice de galhas (IG) e de massas de ovos (IMO), número de nematóides no sistema radicular (NSR) e por grama de raiz (NGR) e reação (R) de Meloidogyne javanica em fruteiras de clima temperado aos 120 dias após a inoculação de 5.000 ovos por planta em 0,5 litros de solo.

\begin{tabular}{|c|c|c|c|c|c|c|c|c|}
\hline Fruteiras & IG & IMO & $\mathrm{NSR}^{1}$ & & & $\overline{\text { NGR }^{1}}$ & & Reação $^{2}$ \\
\hline GF $677^{3}$ & 5,0 & 3,3 & 14588,3 & $\mathrm{a}$ & & 945,2 & $\mathrm{a}$ & $\mathrm{S}$ \\
\hline G x N 9 & 3,3 & 1,4 & 801,3 & $\mathrm{~b}$ & & 146,7 & $\mathrm{~b}$ & $\mathrm{R}$ \\
\hline G x N 15 & 2,5 & 1,5 & 557,5 & $\mathrm{bcd}$ & & 142,5 & $\mathrm{bc}$ & $\mathrm{R}$ \\
\hline Tsukuba 2 & 3,8 & 2,4 & 313,8 & $\mathrm{bc}$ & & 42,9 & $\mathrm{bcd}$ & $\mathrm{R}$ \\
\hline Tsukuba 1 & 3,3 & 1,3 & 200,0 & $\mathrm{bc} \mathrm{d}$ & & 28,3 & $\mathrm{bcd}$ & $\mathrm{R}$ \\
\hline Keaumi & 0 & 0 & 187,5 & $\mathrm{bc} \mathrm{d} \mathrm{e}$ & & 43,7 & $\mathrm{bcde}$ & $\mathrm{R}$ \\
\hline G x N 22 & 1,3 & 0,8 & 92,5 & $b c d$ e $f$ & & 28,6 & bc def & $\mathrm{R}$ \\
\hline Tsukuba 3 & 2,5 & 0,9 & 102,5 & $\mathrm{bc} \mathrm{d}$ & & 13,1 & bc def & $\mathrm{R}$ \\
\hline Keauhou & 0 & 0 & 90,0 & $\mathrm{bc} d$ e $f \mathrm{~g}$ & & 13,6 & $\mathrm{bcdef} g$ & $\mathrm{R}$ \\
\hline Arbequina & 0,4 & 0 & 86,3 & $\mathrm{bcde}$ & & 29,0 & $\mathrm{bcd}$ & $\mathrm{R}$ \\
\hline Waialua & 0 & 0 & 80,0 & $\mathrm{c} \mathrm{d} \mathrm{e} \mathrm{f} \mathrm{g} \mathrm{h}$ & & 13,4 & $\mathrm{cdef} g$ & $\mathrm{R}$ \\
\hline Mizuho & 0 & 0 & 78,8 & $\mathrm{~d}$ e f g h & $\mathrm{i}$ & 50,8 & $\mathrm{cdef} g$ & $\mathrm{R}$ \\
\hline Japão & 0 & 0 & 66,3 & $d$ e $f g h$ & $\mathrm{i}$ & 34,8 & $\mathrm{cdef} g$ & $\mathrm{R}$ \\
\hline Ébano & 0 & 0 & 61,3 & $\mathrm{~d}$ e $\mathrm{f} g \mathrm{~h}$ & $1 \mathrm{i}$ & 8,4 & $d$ e $f g$ & $\mathrm{R}$ \\
\hline Kumagai & 0 & 0 & 21,3 & $\mathrm{fg} \mathrm{h}$ & $\mathrm{i}$ & 2,6 & $\mathrm{f} \mathrm{g}$ & $\mathrm{R}$ \\
\hline Sassaoka & 0 & 0 & 15,0 & $\mathrm{fgh}$ & $\mathrm{i}$ & 2,4 & $\mathrm{f} \mathrm{g}$ & $\mathrm{R}$ \\
\hline Boisenberry & 0,6 & 0 & 8,8 & e $f g h$ & $\mathrm{i}$ & 9,5 & de $f g$ & $\mathrm{R}$ \\
\hline Precoce de Campinas & 0 & 0 & 8,8 & $\mathrm{fg} \mathrm{h}$ & $\mathrm{i}$ & 6,0 & e $f \mathrm{~g}$ & $\mathrm{R}$ \\
\hline Umê & 0 & 0 & 6,3 & $\mathrm{~g} \mathrm{~h}$ & $\mathrm{i}$ & 1,4 & $\mathrm{fg}$ & $\mathrm{R}$ \\
\hline Paluma & 0 & 0 & 3,8 & $\mathrm{~g} \mathrm{~h}$ & $\mathrm{i}$ & 0,6 & g & $\mathrm{R}$ \\
\hline Kakedo & 0 & 0 & 3,8 & $\mathrm{~g} \mathrm{~h}$ & $\mathrm{i}$ & 0,6 & $\mathrm{~g}$ & $\mathrm{R}$ \\
\hline Okinawa $^{4}$ & 3,8 & 0 & 2,5 & $\mathrm{~h}$ & $\mathrm{i}$ & 0,6 & g & $\mathrm{R}$ \\
\hline D’água & 0 & 0 & 0 & & i & 0 & $\mathrm{~g}$ & $\mathrm{R}$ \\
\hline Keaudo & 0 & 0 & 0 & & $\mathrm{i}$ & 0 & $\mathrm{~g}$ & $\mathrm{R}$ \\
\hline Parmogi & 0 & 0 & 0 & & $\mathrm{i}$ & 0 & $\mathrm{~g}$ & $\mathrm{R}$ \\
\hline Néctar de Cristal & 0 & 0 & 0 & & $\mathrm{i}$ & 0 & $\mathrm{~g}$ & $\mathrm{R}$ \\
\hline M 9 & 0 & 0 & 0 & & $\mathrm{i}$ & 0 & $\mathrm{~g}$ & $\mathrm{R}$ \\
\hline MM 106 & 0 & 0 & 0 & & $\mathrm{i}$ & 0 & $\mathrm{~g}$ & $\mathrm{R}$ \\
\hline Maruba & 0 & 0 & 0 & & $\mathrm{i}$ & 0 & $\mathrm{~g}$ & $\mathrm{R}$ \\
\hline Taiwan Nashi - C & 0 & 0 & 0 & & $\mathrm{i}$ & 0 & $\mathrm{~g}$ & $\mathrm{R}$ \\
\hline
\end{tabular}

${ }^{\mathrm{T}}$ Médias originais seguidas da mesma letra, na coluna, não diferem entre si estatisticamente (Tukey 5\%) (dados transformados em $\log \mathrm{x}+1$ na análise)

${ }^{2} \mathrm{R}=$ resistência; $\mathrm{S}=$ susceptibilidade

${ }^{3}$ Referência de susceptibilidade

${ }^{4}$ Referência de resistência 
Um segundo grupo formado por 'Kyoto', 'Rama Forte' e $D$. virginiana foi considerado intermediário, com valores de NI variando de 6,1 a 4,9, de NSR de 136,3 a 43,4 e de NGR de 60,0 a 19,6, respectivamente para 'Kyoto' e D. virginiana. Em 'Pomelo', 'Coral' e 'Fuyuanna', o NI variou de 5,5 em 'Pomelo' a 4,6 em 'Fuyuanna'. Entretanto, não se extraíram nematóides após 120 dias da inoculação e tampouco se observaram massas de ovos externas nas raízes dos genótipos avaliados. No experimento com $M$. javanica, obtiveram-se resultados similares aos referentes a $M$. incognita, com todos os genótipos reagindo como resistentes (Tabela 15). Os valores de NI variaram de 0 para 'Fuyuanna' e D. virginiana a 2,6 para 'Pomelo'. Não se verificaram diferenças estatísticas entre as médias de NSR e NGR. O maior valor numérico foi encontrado em 'Fuyuanna' com 1 023,8 e 108,8 e o menor em D. virginiana com 45,0 e 20,6 para NSR e NGR, respectivamente.

\subsection{Patogenicidade de Meloidogyne incognita ao caquizeiro}

Os resultados de avaliações de diâmetro, altura e massa seca de parte aérea e de raízes do caquizeiro 'Kyoto' avaliados aos seis meses da inoculação estão contidos na Tabela 16. Os dados apresentaram alta variabilidade com presença de observações discrepantes, representadas pelos asteriscos (Figuras 2 a 5). As análises de regressão não indicam efeito significativo dos níveis populacionais sobre as quatro variáveis. A causa disso é a alta variação nos dados (Figuras 2 a 5). Nesse caso, optou-se por utilizar as médias das repetições, o que permitiu um melhor ajustamento dos modelos de regressão.

As análises de regressão linear, utilizando as médias das repetições para as variáveis dependentes: diâmetro, altura e massa seca de parte aérea e variável independente nível populacional não foram significativos $(\mathrm{P}>0,05)$ obtendo valores de coeficiente de determinação muito baixos: 0; 3,5 e 39,0 \%, respectivamente. 
Tabela 14. Médias de notas de infestação (NI), número de nematóides no sistema radicular (NSR) e por grama de raiz (NGR) de Meloidogyne incognita raça 2 em genótipos de caquizeiro aos 120 dias após a inoculação de 5000 ovos por planta.

\begin{tabular}{llrlrlll}
\hline \multicolumn{1}{c}{ Genótipos } & NI & \multicolumn{1}{c}{ NSR $^{1}$} & \multicolumn{5}{c}{ NGR $^{\mathbf{1}}$} \\
\hline Regina & 6,1 & 2275,6 & $\mathrm{a}$ & 260,8 & $\mathrm{a}$ & \\
Kyoto & 6,1 & 136,3 & $\mathrm{~b}$ & 60,0 & $\mathrm{~b}$ & \\
Rama Forte & 4,6 & 47,5 & $\mathrm{~b}$ & 17,3 & $\mathrm{~b}$ & \\
D. virginiana & 4,9 & 43,4 & $\mathrm{~b}$ & 19,6 & $\mathrm{~b}$ & \\
Pomelo & 5,5 & 0 & $\mathrm{c}$ & 0 & $\mathrm{c}$ \\
Coral & 4,4 & 0 & $\mathrm{c}$ & 0 & $\mathrm{c}$ \\
Fuyuanna & 4,6 & 0 & $\mathrm{c}$ & 0 & $\mathrm{c}$ \\
\hline
\end{tabular}

${ }^{1}$ Dados transformados em $\log \mathrm{x}+1$ na análise; médias originais seguidas da mesma letra, na coluna, não diferem entre si estatisticamente pelo teste de Tukey (5\%).

Tabela 15. Médias de notas de infestação (NI), número de nematóides no sistema radicular (NSR) e por grama de raiz (NGR) de Meloidogyne javanica em genótipos de caquizeiros aos 120 dias após a inoculação de 5000 ovos por planta (dados de NSR e NGR transformados em $\log \mathrm{x}+1$ para a análise).

\begin{tabular}{lccc}
\hline \multicolumn{1}{c}{ Genótipos } & NI & NSR $^{*}$ & NGR $^{*}$ \\
\hline Fuyuanna & 0 & 1023,8 & 108,8 \\
Coral & 1,9 & 485,0 & 122,5 \\
Regina & 2,3 & 216,3 & 30,1 \\
Pomelo & 2,6 & 158,8 & 34,6 \\
Rama Forte & 0,9 & 117,5 & 37,3 \\
Kyoto & 1,5 & 46,3 & 29,2 \\
D. virginiana & 0 & 45,0 & 20,6 \\
\hline
\end{tabular}

* Na análise estatística, os valores de $\mathrm{F}$ obtidos não foram significativos. 
Portanto, os níveis populacionais dos nematóides não apresentam efeito linear significativo sobre as variáveis. No caso de massa seca de raízes, o resultado de análise de regressão foi significativo $(P \leq 0,05)$ com coeficiente de determinação igual a 75,3 \%.

Eliminando-se a média do nível populacional “4000” e aplicando-se nova análise de regressão linear observa-se que a variável altura mostrou-se com resultado significativo e coeficiente de determinação igual a $85 \%$ (Figura 6). Procedendo da mesma forma, ou seja, eliminando-se o nível "160", a equação linear negativa da média de matéria seca de raízes em função do logaritmo dos níveis populacionais, ajusta-se aos dados experimentais (Figura 7). Nesse baixo nível inicial de inóculo, uma resposta positiva da planta ao fitoparasitismo pode e até costuma ocorrer, comumentemente na forma de estímulo à produção de novas radicelas, diferentemente do que ocorre quando a planta é exposta ao ataque por níveis populacionais mais elevados do nematóide. A equação ajustada encontra-se na respectiva figura e apresenta coeficiente de determinação igual a 99,3 \%, indicando que a variável "nível populacional do nematóide" explica 99,3 \% da variação observada na massa seca de raízes.

Tabela 16. Efeito de níveis populacionais iniciais crescentes de Meloidogyne incognita sobre a altura, o diâmetro do caule e as massas secas da parte aérea (MSPA) e de raízes (MSR) do caquizeiro 'Kyoto'.

\begin{tabular}{lccccc}
\hline \multicolumn{1}{c}{ Nível } & Log & Diâmetro & Altura & MSPA & MSR \\
\hline 0 & & 4,75 & 198,63 & 753,75 & 4260,0 \\
160 & 2,2 & 5,13 & 175,0 & 805,0 & $\mathbf{4 4 1 8 , 7 5}$ \\
800 & 2,9 & 4,63 & 157,50 & 723,75 & 2873,75 \\
4000 & 3,6 & 5,13 & $\mathbf{2 2 0 , 8 8}$ & 772,50 & 2331,25 \\
20000 & 4,3 & 4,25 & 144,38 & 511,25 & 1983,75 \\
100000 & 5,0 & 4,63 & 153,0 & 450,0 & 1698,75 \\
P & - & 0,531 & 0,338 & 0,110 & 0,016 \\
P (s/ o.d. $\left.{ }^{1}\right)$ & - & - & 0,017 & - & 0 \\
R (\%) & - & 0 & 3,5 & 39,0 & 75,3 \\
R (s/ o.d.) & - & - & 85 & - & 99,3 \\
\hline
\end{tabular}

\footnotetext{
${ }^{1}$ Retirando-se observação discrepante.
} 


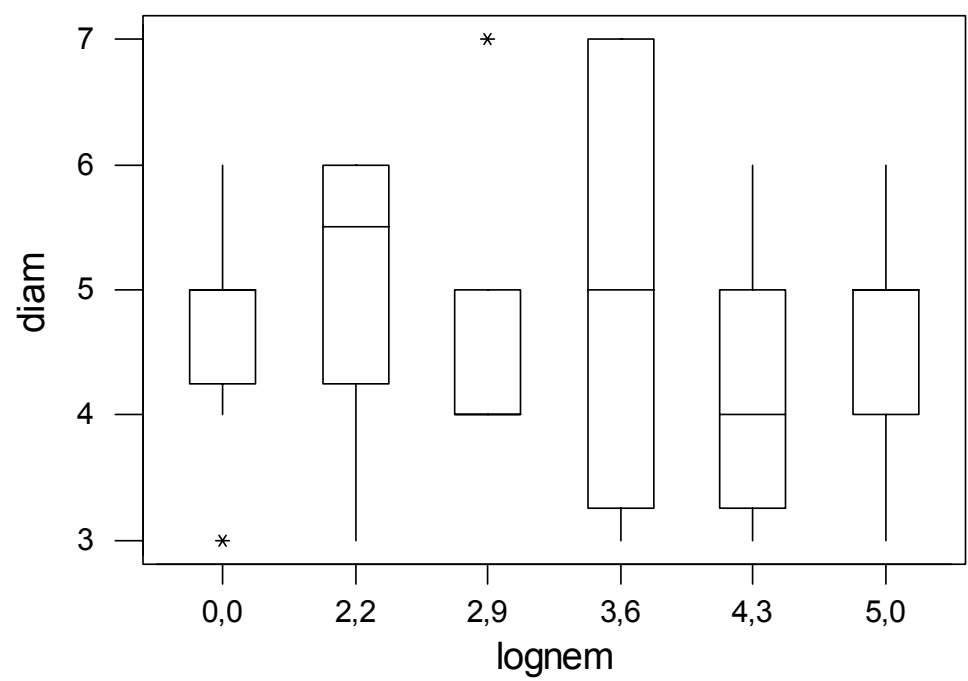

Figura 2 - Distribuição dos dados de diâmetro de caquizeiros 'Kyoto' em relação ao nível populacional de Meloidogyne incognita raça 2.

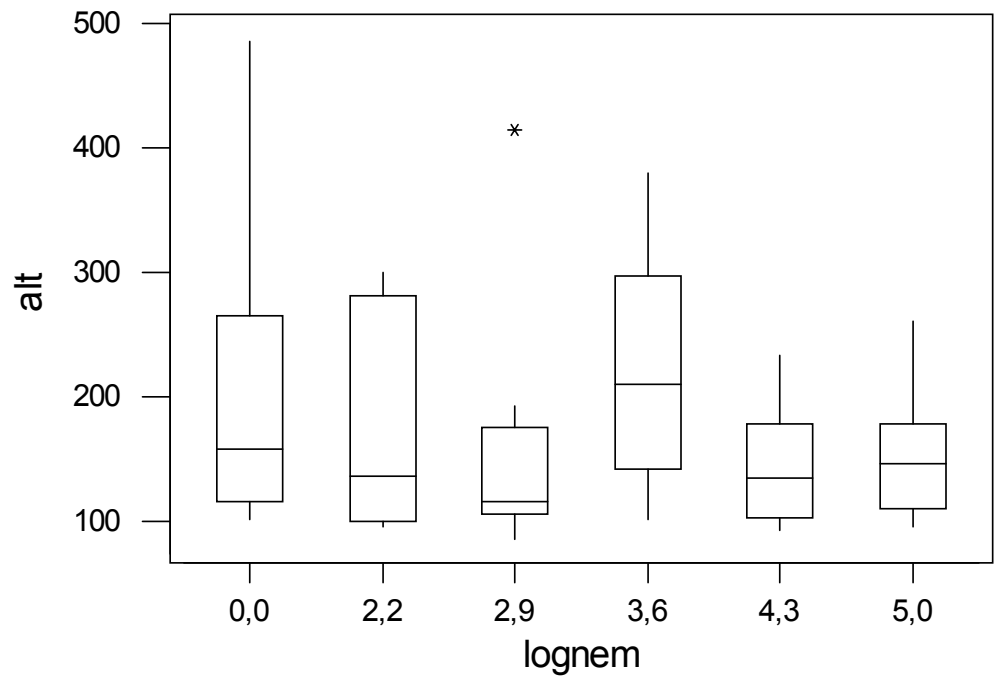

Figura 3 - Distribuição dos dados de altura de caquizeiros 'Kyoto' em relação ao nível populacional de Meloidogyne incognita raça 2. 


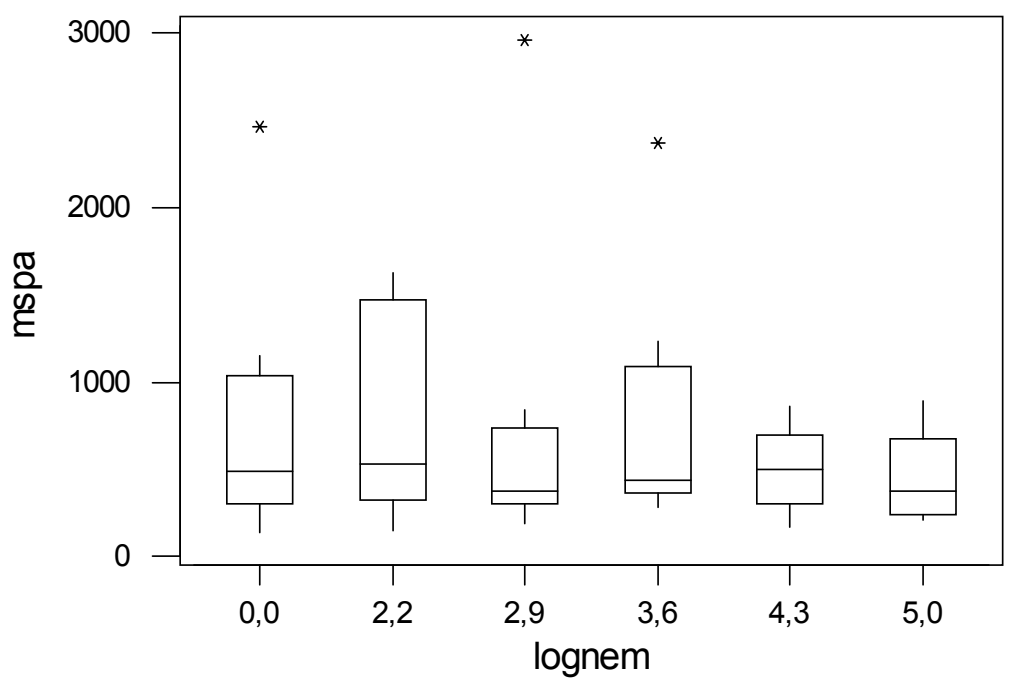

Figura 4 - Distribuição dos dados de massa seca de parte aérea de caquizeiros 'Kyoto' em relação ao nível populacional de Meloidogyne incognita raça 2.

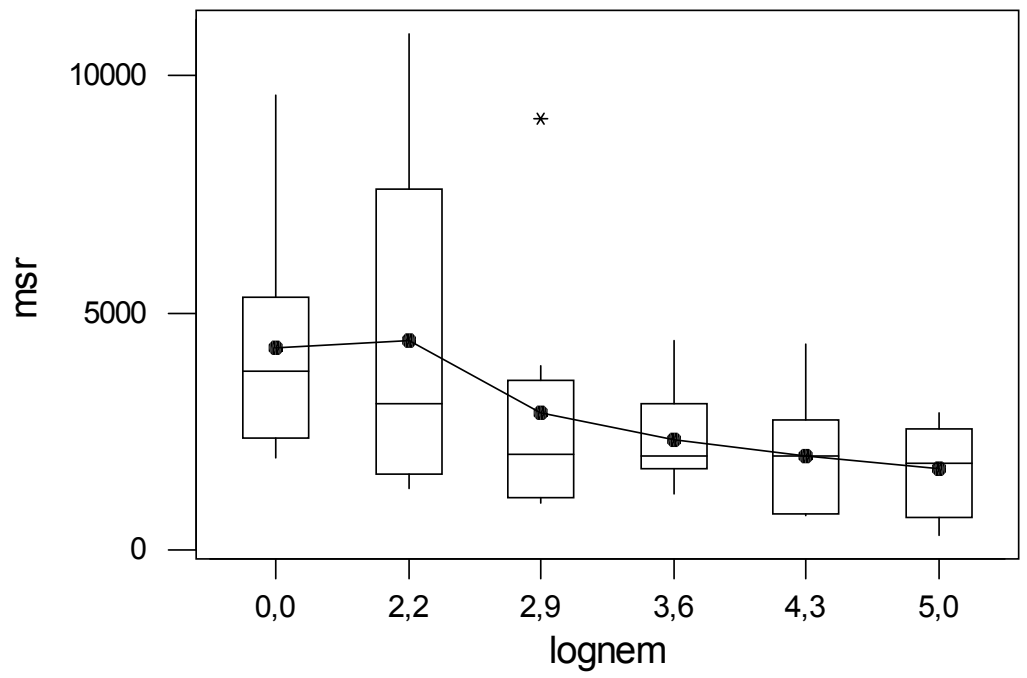

Figura 5 - Distribuição dos dados de massa seca de raízes de caquizeiros 'Kyoto' em relação ao nível populacional de Meloidogyne incognita raça 2. 


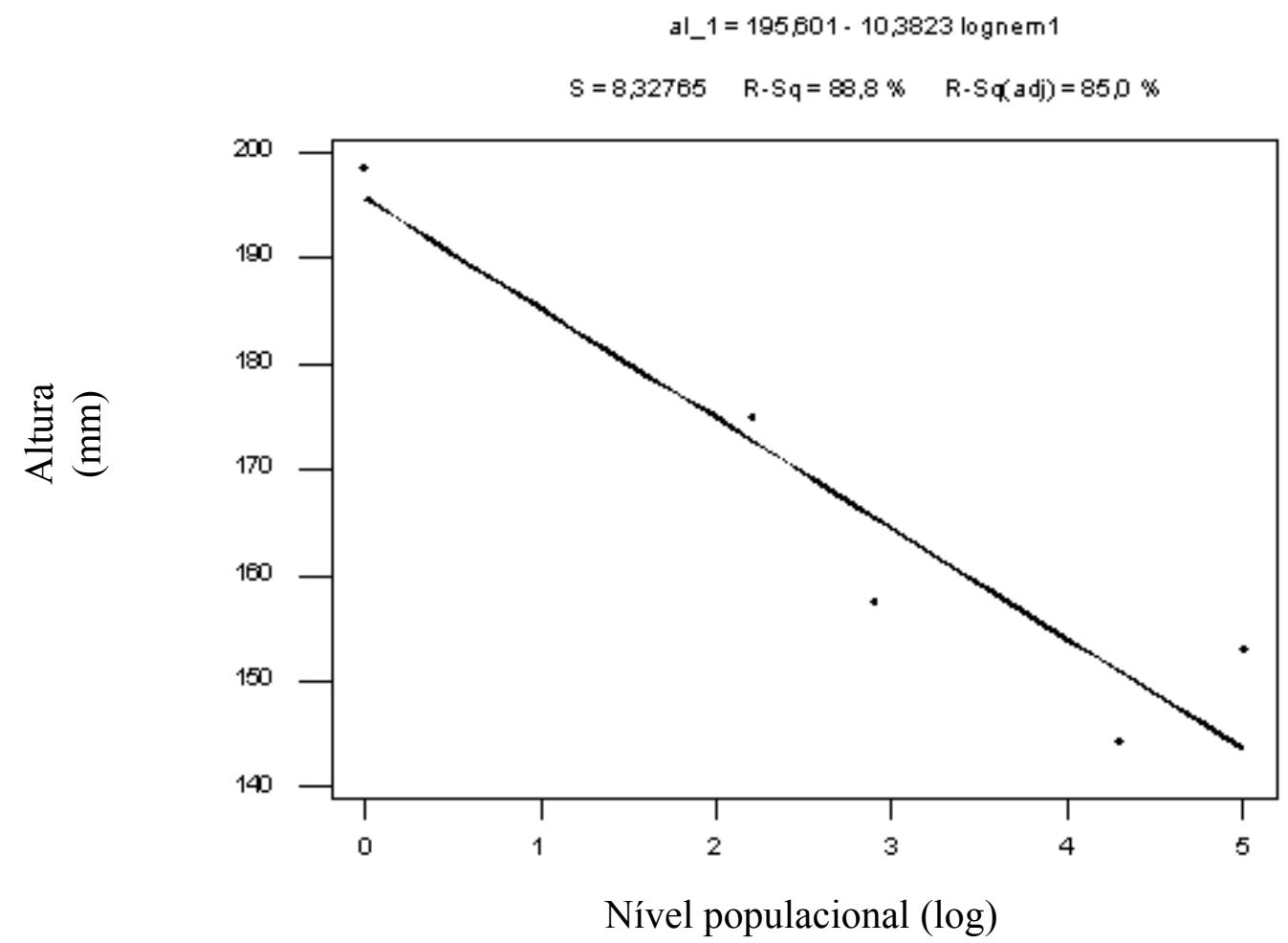

Figura 6 - Efeito de Meloidogyne incognita raça 2 sobre a altura de caquizeiros 'Kyoto'.

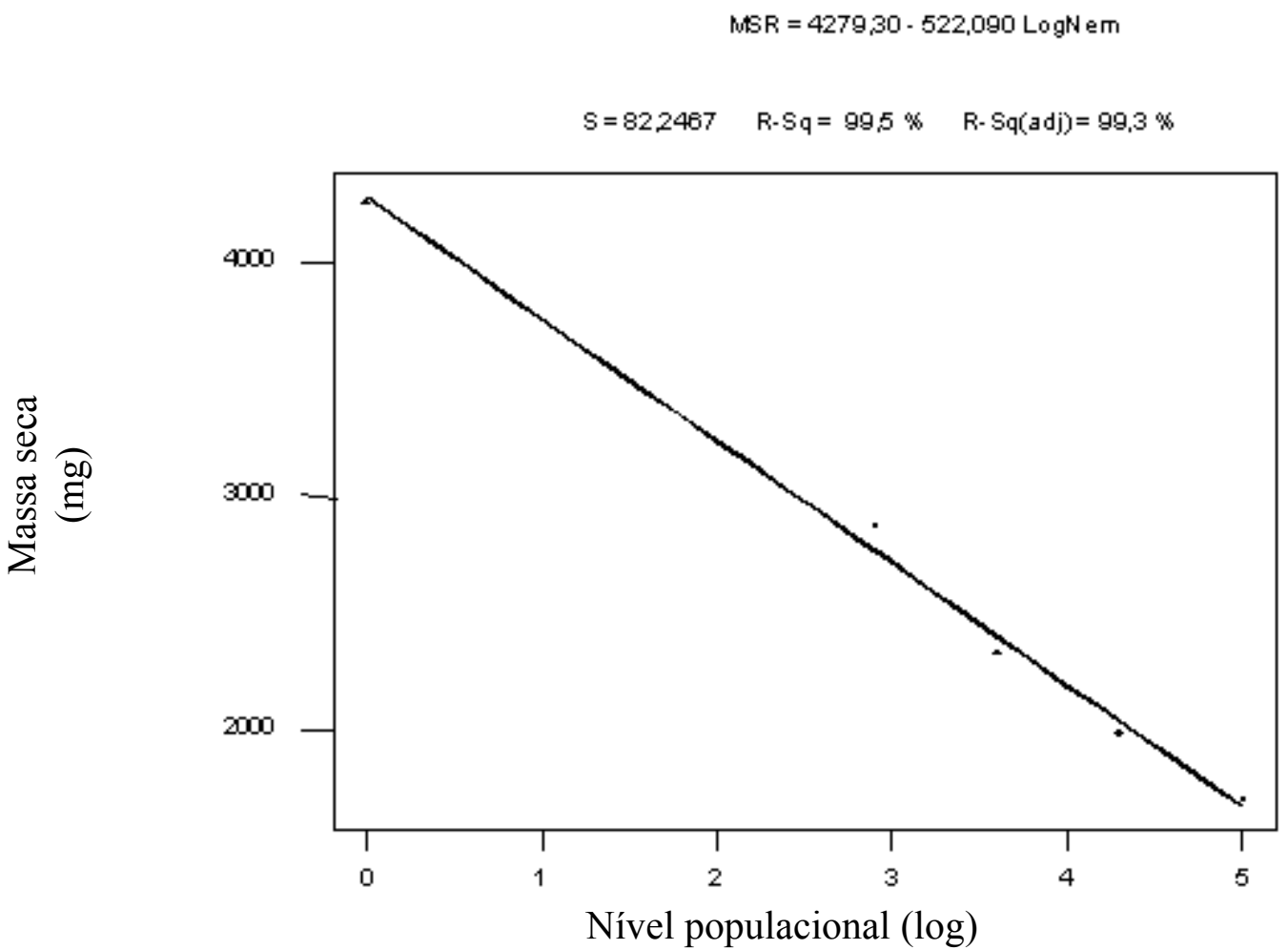

Figura 7- Efeito de Meloidogyne incognita raça 2 sobre a massa seca de raízes de caquizeiros 'Kyoto'. 


\section{DISCUSSÃO}

\subsection{Levantamento de Nematóides}

Os resultados da freqüência de nematóides de vida livre, não fitoparasitos, evidenciam a abundância desses organismos no solo, fato constantemente verificado em levantamentos congêneres e especialmente em estudos relacionados à composição das comunidades nematológicas em ecossistemas, naturais ou cultivados (Cares \& Huang, 1991; Huang et al., 1996; Ferris \& Ferris, 1998).

Considerando apenas os fitonematóides, verificou-se predominância de espécies ectoparasitas e semi-endoparasitas na rizosfera das fruteiras amostradas durante o levantamento. Dos 11 gêneros encontrados, apenas Meloidogyne e Pratylenchus incluem formas endoparasitas. As espécies de Aorolaimus, Discocriconemella, Helicotylenchus, Hemicycliophora, Mesocriconema, Scutellonema, Rotylenchulus, Tylenchulus e Xiphinema são ectoparasitas ou semi-endoparasitas. No geral, ocorreu semelhança em relação aos resultados encontrados por alguns outros autores em levantamentos nematológicos anteriores desenvolvidos no Brasil, envolvendo ou não plantas frutíferas (Sharma, 1973; 1974; Ferraz, 1980; Becker, 1991; Carneiro et al., 1993; Maximiniano et al., 1999; Souza et al., 1999).

Dentre os nematóides encontrados no presente levantamento, espécies de Meloidogyne, Mesocriconema, Pratylenchus, Tylenchulus e Xiphinema têm sido freqüentemente associadas com algum tipo de dano causado às espécies de fruteiras aqui estudadas (McElroy, 1972; McSorley, 1992; Brown et al., 1993; Nyczepir \& Becker, 1998). 


\section{Família Criconematidae}

Das dez espécies de Mesocriconema registradas no Brasil (Costa Manso et al., 1994), identificaram-se quatro no presente trabalho: $M$. onoense, M. ornata, $M$. sphaerocephalum e M. xenoplax.

Mesocriconema xenoplax foi detectado principalmente em pessegueiro, o que indica uma certa especialização por essa planta. Orton Williams (1972) afirmou que os hospedeiros desse nematóide são quase sempre plantas arbóreas. No Brasil, foi assinalado associado a pessegueiro (Ferraz, 1980; Monteiro et al., 1990; Sperandio, 1992; Carneiro et al., 1993), nogueira-pecan, bananeira e ameixeira (Ferraz, 1980) e cafeeiro (Campos et al., 1987). Ilustrando essa especialização, Bird \& Melakeberhan (1995) relataram que essa espécie pode induzir modificações celulares elaboradas nas raízes no momento da alimentação, o que lhe permite utilizar por até oito dias um único sítio de alimentação.

O fato de estar entre as espécies mais abundantes detectadas no trabalho concorda com os resultados obtidos por Nyczepir et al. (1985), que encontrou M. xenoplax e $M$. ornata em $100 \%$ dos pomares de pessegueiro amostrados. No trabalho atual não houve coexistência de espécies de Mesocriconema em uma mesma amostra, o que sugere possível dominância sobre as demais espécies de nematóides anelados nessa hospedeira nos locais amostrados. Os mesmos autores encontraram $M$. sphaerocephalum em poucos pomares, o que também concorda com o resultado ora observado.

Carneiro et al. (1993) verificaram que o nível populacional de M. xenoplax para causar a doença complexa VCP no Rio Grande do Sul foi igual ou superior a 1000 exemplares / $100 \mathrm{~cm}^{3}$ de solo. A única amostra do presente levantamento em que o resultado aproximou-se desse nível foi a do sítio Natal, em Campos do Jordão. Coincidentemente, o relato inicial da espécie associada a pessegueiros (porta-enxerto 'Okinawa'; copa 'Rubra-sol') com evidentes sintomas de declínio rápido no Brasil (Monteiro et al., 1990) ocorreu em propriedade localizada no município de Santo Antonio do Pinhal, vizinho a Campos do Jordão. Apesar disso e mesmo sendo o clima da região propício à ocorrência do mal, não se observaram sintomas de VCP nas plantas do 
pomar ora amostrado. De qualquer modo, causa grande preocupação a verificação de $M$. xenoplax em praticamente $40 \%$ das amostras coletadas no Estado de São Paulo, haja vista ser um dos mais importantes fatores bióticos, senão o mais importante, a predispor os pessegueiros a essa seríssima doença. Diferentemente do observado no Rio Grande do Sul (Carneiro et al., 1993; Gomes et al., 2000), onde foi bastante comum, a presença simultânea de M. xenoplax e nematóides de galhas (Meloidogyne incognita ou M. javanica) em níveis populacionais relativamente elevados foi pouco freqüente no presente levantamento.

Segundo listas de plantas hospedeiras contidas em Costa Manso et al. (1994), M. onoense, M. ornata e M. sphaerocephalum podem ser considerados polífagos, sem clara tendência por alguma família botânica ou grupo de plantas com características morfológicas específicas. Em relação às frutíferas estudadas, Mesocriconema onoense foi observada na Bahia associada a goiabeira (Sharma, 1977), M. ornata a ameixeira, nespereira, nogueira-macadâmia e pereira em Minas Gerais (Ferraz, 1980) e $M$. sphaerocephalum a pessegueiro em Minas Gerais (Maximiniano et al., 1999) e a caquizeiro (D. discolor) e nogueira-macadâmia nos EUA (McSorley, 1982). Porém, no presente levantamento houve poucas ocorrências. Muito possivelmente, há muitas outras associações entre nematóides anelados e fruteiras a serem descobertas no Brasil; evidência disso são os vários trabalhos relatando ocorrência de Mesocriconema spp. associados a diferentes espécies frutíferas (Ferraz, 1980; Monteiro et al., 1987; Becker, 1991; Gomes, 2001).

Quanto aos outros criconematídeos identificados, há citações de associações de Discocriconemella a fruteiras no Brasil. Becker (1991) encontrou representantes desse gênero em pomares de macieira em Santa Catarina e segundo o catálogo de Costa Manso et al. (1994) a espécie $D$. degrissei ocorreu em cacau e solo de mata na Bahia e solo de floresta em Minas Gerais. Maximiniano et al. (1999) encontrou essa mesma espécie em pessegueiro em Minas Gerais. No presente estudo, ocorreu apenas de forma eventual, esporádica.

O gênero Hemicycliophora já foi observado em Rubus (Esnard \& Zuckerman, 1998) e goiabeira (Sharma, 1977; Moreira et al., 2001). Em macieira, Ferraz (1980) 
identificou a espécie $H$. oostenbrinki. A espécie encontrada no presente trabalho, $H$. poranga, foi descrita no Brasil a partir de exemplares extraídos de repolho, por Monteiro \& Lordello (1978). Em relação às fruteiras ora estudadas, havia sido antes detectada associada ao pessegueiro por Sperandio (1992) no Rio Grande do Sul e Maximiniano et al. (1999) em Minas Gerais. Entretanto, há fortes evidências de que seja polífaga, pois Costa Manso (1996) já caracterizara populações brasileiras encontradas na rizosfera de morangueiro, arroz e Musa paradisiaca e Sperandio (1992) a assinalara também em associação com alfafa, citros, eucalipto e hortênsia.

\section{Família Heteroderidae}

Em todos os locais em que se detectaram espécies de Meloidogyne parasitando pessegueiro, o porta-enxerto não era um genótipo resistente. Não se observou a presença de nematóides de galhas atacando pessegueiros 'Okinawa'. Essa informação concorda com os trabalhos da literatura internacional (Burdett et al., 1963; Sharpe et al., 1969; Siniscalco et al., 1976; Philis, 1989; Torrallardona, 1993) e nacional (Menten et al., 1977; Scherb et al., 1993; Fachinello et al., 2000). Entretanto, no trabalho de Maximiniano et al. (1999), os autores observaram populações de M. incognita em raízes de pessegueiros dessa cultivar em 53,4 \% das amostras. Esse é um fato novo no Brasil, já que esse genótipo é amplamente conhecido como referência de resistência e, até mesmo, de imunidade a certas espécies de nematóides de galhas. Há apenas relatos esparsos de reprodução de M. incognita raça 3 (Sherman et al. 1991) e M. hapla (Sharpe et al., 1969) em 'Okinawa' e 'Nemaguard'. Entretanto, recentemente, evidências surgiram de suscetibilidade do porta-enxerto com relação a uma população oriunda da Flórida (EUA), que foi primeiro caracterizada como $M$. incognita raça 3, mas depois verificou-se diferir nos padrões bioquímicos e morfométricos tanto de $M$. incognita como de $M$. arenaria, M. hapla e M. javanica (Nyczepir et al., 1998).

Com relação a danos, Lownsbery (1959) afirmou que cinco ou mais juvenis de segundo estádio de $M$. incognita por grama de solo poderiam reduzir severamente a massa fresca de plântulas de pessegueiro 'Lovell'. Em três (um pomar em Brotas e dois 
em Guapiara) dos cinco locais onde ocorreu Meloidogyne, os níveis encontravam-se acima desse valor. De acordo com Pinochet (1995), a maturação fisiológica de tecidos radiculares de pessegueiros varia conforme a idade da planta, podendo tornar-se barreira mecânica à penetração do nematóide. Dessa forma, mesmo sendo suscetíveis quando no estágio de plântulas, plantas mais velhas poderão ser resistentes ou tolerantes ao parasito. Em Guapiara, plantas adultas infestadas não manifestavam sintomas de perda de vigor ou evidente queda de produção. Todavia, no sítio Ohashi (Atibaia), onde o porta-enxerto era reconhecidamente suscetível, foi possível observar redução no vigor, crescimento e produção em plantas adultas. Nyczepir \& Becker (1998) já destacaram que a redução no desenvolvimento de pessegueiros suscetíveis pode ser detectada, usualmente, a partir do segundo ano. Na Fazenda Taperão (Brotas), observaram-se plantas jovens com aparente interrupção do desenvolvimento seguida de declínio rápido até a morte. Fato semelhante havia acontecido no sítio Ohashi em cultivos anteriores.

Meloidogyne hapla ocorreu em plantas de amoreira-preta com sintomas de galhas causadas por Agrobacterium. Entretanto, tentativas de isolamento da bactéria para confirmação do agente causal no laboratório de bacteriologia do Instituto Biológico não revelaram a presença de patógenos (observação não publicada).

Meloidogyne incognita e M. javanica são as espécies mais daninhas para as oliveiras plantadas nos países que beiram o Mar Mediterrâneo, onde o cultivo é muito intensivo (Hashim, 1982). Na literatura nacional, há somente uma referência de parasitismo de M. javanica em oliveira no Rio Grande do Sul (Lordello \& Marini, 1974). No presente estudo, verificou-se a ocorrência de $M$. incognita raça 1 em São Bento do Sapucaí, único local amostrado com essa fruteira. O nível populacional observado pode ser considerado baixo e não se observaram sintomas de declínio nas plantas cultivadas na área.

Há contradição sobre a reação do marmeleiro em relação a Meloidogyne. Tufts \& Day (1934) e Pinochet et al. (1990) consideraram-no resistente, enquanto Buhrer et al. (1933) o classificaram como suscetível. No estudo atual, verificou-se a presença de $M$. incognita raça 2 no solo e nas raízes de marmeleiro (Cydonia oblonga) 'Portugal' em Itaberá, cuja copa era pereira d'água. A discrepância, ao que tudo indica, está ligada aos 
diferentes tipos de marmeleiro disponíveis para utilização prática (ver item 5.2, na seqüência), que podem apresentar respostas distintas em relação ao parasitismo por espécies e raças de Meloidogyne.

Encontrou-se $M$. incognita raça 1 parasitando mudas de caquizeiro destinadas ao transplantio em Guararema, fato lastimável e que vem confirmar o relato de Inomoto et al. (1991) de que esse nematóide é parasito de caquizeiro. Entretanto, não se encontraram nematóides de galhas em nenhum dos pomares dessa fruteira amostrados, ou seja, sob condição de cultivo de campo.

Não se observou a presença de Meloidogyne spp. em pereiras e macieiras, consideradas hospedeiras de algumas espécies desse gênero.

\section{Família Hoplolaimidae}

Não surpreende que Helicotylenchus dihystera tenha ocorrido com freqüência relativamente alta. Observações de Sharma (1977) no Estado da Bahia, Becker (1991) em Santa Catarina, Ferraz (1980) e Maximiniano et al. (1999) em Minas Gerais e Souza et al. (1999) em diferentes Estados brasileiros corroboram as do presente estudo, levando em conta somente levantamentos em fruteiras. Em todos esses trabalhos, o gênero Helicotylenchus apareceu em altas porcentagens em relação ao número total de amostras coletadas na rizosfera de fruteiras. Possivelmente, características reprodutivas e respostas fisiológicas dessa espécie às condições ambientes facilitem a ocorrência de tal fenômeno. Esse nematóide já havia sido assinalado em caquizeiros em Pernambuco por Sharma (1973), pessegueiros e pereiras em Minas Gerais (Ferraz, 1980) e Rubus em São Paulo por Monteiro \& Lordello (1976). Apesar de alguns trabalhos desenvolvidos sob condições experimentais de casa de vegetação e envolvendo utilização de altos níveis populacionais terem possibilitado a demonstração da patogenicidade de $H$. dihystera a algumas espécies de plantas, como o cacaueiro por exemplo (Luna, 1976), acredita-se que a espécie não cause danos significativos sob condições de campo, inclusive em fruteiras (McSorley, 1992). 
As demais espécies de Helicotylenchus identificadas, $H$. erythrinae, $H$. microcephalus e H. pseudorobustus, já haviam sido registradas no Brasil, mas não nas fruteiras aqui relatadas; o exame da literatura mostrou que, em relação a elas, não há outros estudos além dos simples assinalamentos.

Com relação aos outros hoplolaimídeos encontrados, começando por Aorolaimus nigeriensis, há de se destacar o assinalamento pela primeira vez da espécie no Estado de São Paulo, em três amostras, o que amplia a sua distribuição geográfica. No passado, observaram-se raras ocorrências no País, tendo sido registrada em vegetação de cerrado em Brasília, DF (Bittencourt \& Huang, 1986) e associada a cacaueiro na Bahia (Rashid et al., 1987). Aorolaimus nigeriensis e outras espécies do gênero têm sido detectadas com grande freqüência em amostras de solo coletadas junto a vegetação natural e plantas cultivadas na região Nordeste, por vezes em níveis populacionais aparentemente muito altos. Lamentavelmente, porém, inexistem até o momento maiores estudos a respeito da ação patogênica e dos danos causados por esse grupo de nematóides.

Scutellonema brachyurus, como A. nigeriensis, foi encontrado em poucas amostras (quatro), mas procedentes de diferentes localidades paulistas. No entanto, tratase de espécie sabidamente ocorrente no Estado de São Paulo e com distribuição geográfica em todo o País possivelmente bem mais ampla que a de A. nigeriensis. Juntamente com S. bradys, são as duas espécies mais comuns do gênero no Brasil (Costa Manso et al., 1994). Dentre as fruteiras estudadas, apenas o pessegueiro havia sido antes mencionado como planta hospedeira de S. brachyurus (Sher, 1963). Também para esta espécie não se dispõe de estudos relacionados à patogenicidade em fruteiras subtropicais e temperadas.

Por fim, o nematóide reniforme, Rotylenchulus reniformis, já foi encontrado associado a caquizeiro (D. kaki) e goiabeira por Sharma (1977) na Bahia e em pereira por Ferraz (1980) em Minas Gerais. No Exterior, há também relato de associação com os caquizeiros D. discolor, D. ebenaster e D. senegalensis (McSorley et al., 1982). No presente estudo, detectaram-se apenas fêmeas imaturas e machos em solo de mudas de marmeleiro e em pomar de pessegueiro, sem terem sido encontradas fêmeas maduras nas raízes. Como esse nematóide é muito persistente no solo e tem ampla gama de 
hospedeiros (Siddiqi, 1972), não é possível afirmar, somente baseado no encontro do nematóide no solo, de que estivesse havendo relação de parasitismo com as fruteiras citadas, embora haja suspeita disso. É oportuno destacar que, na verdade, nos relatos referentes aos levantamentos de Sharma (1977) e Ferraz (1980), ao que tudo indica, ocorreu a mesma situação. Essa espécie é cosmopolita e mostra-se largamente disseminada no Brasil. É muito prejudicial ao algodoeiro em todo o mundo. Entre as fruteiras tropicais, multiplica-se bem em bananeira e nos maracujazeiros amarelo e roxo, sendo que estes últimos podem ter o crescimento e a produtividade seriamente afetados. Em vista disso, sugere-se que novas observações sejam procedidas futuramente visando ao devido esclarecimento das reações dos pessegueiros e marmeleiros mais utilizados no Brasil frente a R. reniformis.

\section{Família Longidoridae}

Novas ocorrências de Xiphinema em fruteiras puderam ser assinaladas neste estudo. Entretanto, X. brevicollum, X. elongatum, X. krugi e espécie não identificada do grupo de $X$. americanum já haviam sido antes identificados em solo de rizosfera de pessegueiros em São Paulo, Minas Gerais e Rio Grande do Sul (Lordello \& Zamith, 1960b; Ferraz, 1980; Carneiro et al., 1993; Maximiniano et al., 1999). Além disso, Monteiro et al. (1978) detectaram X. krugi em nespereira e Zem (1977) relatou $X$. surinamense em associação com marmeleiro, ambos no interior paulista.

Das espécies registradas na literatura como causadoras de prejuízos em fruteiras subtropicais e temperadas, a saber, $X$. bakeri, $X$. diversicaudatum e espécies do "grupo de X. americanum" (McElroy, 1972; Brown et al., 1993), apenas X. brevicollum, que está compreendida dentro do citado grupo, foi encontrada durante o levantamento, associada principalmente a caquizeiro, nogueira-macadâmia e pessegueiro. No entanto, em nenhuma das plantas amostradas das quais se obtiveram populações de Xiphinema visualizaram-se sintomas reflexos de ataque do parasito. $\mathrm{Na}$ amostra de pessegueiro procedente de Campos do Jordão, em que ocorreram X. brevicollum e X. krugi, estimaram-se 1.680 nematóides $/ 250 \mathrm{~cm}^{3}$ de solo. Com base nos resultados considera-se 
essa uma exceção, já que as demais amostras continham níveis populacionais mais baixos desses nematóides, possivelmente por causa do método de extração utilizado.

\section{Família Pratylenchidae}

Algumas espécies de Pratylenchus são muito importantes para amoreira-preta, framboeseira, macieira, pereira e pessegueiro na América do Norte e Europa, tais como P. vulnus e P. penetrans (McElroy, 1972; Wehunt, 1984; Pinochet et al., 1992; Nyczepir \& Halbrendt, 1993; Esnard \& Zuckerman, 1998). Apesar de esses nematóides ocorrerem no Brasil (Costa Manso et al., 1994), no atual levantamento não foram detectados, aparentemente por terem restrita distribuição geográfica, particularmente $P$. penetrans. As espécies ora encontradas, $P$. brachyurus e $P$. zeae, são de ocorrência freqüente no Brasil e têm, ao que tudo indica, pouca importância para as fruteiras amostradas (Barker \& Clayton, 1969). Entretanto, Stokes (1966) verificou que elevados níveis populacionais de $P$. brachyurus podem danificar o sistema radicular do pessegueiro e afetar o crescimento da planta. Pratylenchus zeae foi detectada em macieira, nespereira, nogueira-macadâmia, pereira e pessegueiro no Brasil (Ferraz, 1980; Café Filho \& Huang, 1988); McElroy (1972) relatou que, na Austrália, essa espécie foi associada com crescimento reduzido de pessegueiros. Tendo em vista que os exemplares foram obtidos quase exclusivamente de amostras de solo, ressalta a necessidade de novos estudos para melhor aferir a real capacidade de esses nematóides em parasitar e causar danos às citadas fruteiras. De qualquer modo, como as duas espécies multiplicam-se intensamente nas raízes de diferentes gramíneas anuais, podendo atingir níveis populacionais muito altos no solo após a colheita, atenção especial deve ser dada aos casos em que se cogite do estabelecimento de pomares em áreas antes monocultivadas com tal grupo de plantas.

\section{Família Tylenchulidae}

Tylenchulus semipenetrans mostrou-se disseminado nos pomares de caquizeiro amostrados. Em nove das quinze amostras, os níveis populacionais não excederam 1000 
exemplares por $250 \mathrm{~cm}^{3}$ de solo. Entretanto, não se conhece um nível limiar de dano econômico para essa espécie nessa cultura (Cohn \& Duncan, 1990), que pudesse sugerir algum procedimento técnico ou recomendação prática. Em nenhum dos pomares infestados observaram-se sintomas de declínio que pudessem ser relacionados com a presença do nematóide. Citros, oliveira, videira, nespereira e pereira são outras fruteiras hospedeiras desse nematóide (Raski, 1991). Maximiniano et al. (1999), encontraram $T$. semipenetrans em pessegueiro em Minas Gerais. No presente estudo, não se detectou o parasito em pessegueiro, oliveira ou nespereira, mas em caquizeiro e pereira. Também não se verificou a presença concomitante de Meloidogyne spp., conforme assinalado por Inomoto et al. (1991) em pomar de caquizeiro.

\subsection{Capacidade reprodutiva dos nematóides de galhas nas fruteiras}

Como esperado, o porta-enxerto espanhol 'GF 677', que em vários experimentos anteriores desenvolvidos em países estrangeiros respondeu como suscetível e tem até sido utilizado como referência de suscetibilidade a Meloidogyne (Pinochet et al., 1989; 1996; Marull et al., 1994), reagiu da mesma forma no presente estudo. Assim, é possível recomendá-lo para uso em avaliações futuras de resistência de porta-enxertos de Prunus no Brasil. Por outro lado, na maioria dos trabalhos citados na literatura internacional, adotou-se 'G x N 15' como padrão de resistência. Os dados ora obtidos demonstram que tanto 'Okinawa' quanto 'G x N 15' são passíveis de emprego para essa finalidade, apesar dos eventuais nematóides encontrados em suas raízes na avaliação final. Em 'Okinawa', formaram-se galhas quando inoculado com M. javanica, resultado também encontrado por Philis (1989). Isso evidencia que os nematóides (juvenis J2) penetram nas raízes e apresentam desenvolvimento inicial, porém acabam morrendo precocemente devido a mecanismo de resistência da planta, como demonstrado por Malo (1967) em 'Okinawa' e por Marull et al. (1994) em 'G x N 9'. Portanto, só avaliar o número ou o índice de galhas não é suficiente para caracterizar um genótipo de fruteira quanto a resistência a Meloidogyne. É necessário avaliar a reprodução do nematóide. Todos os Prunus, à exceção de umezeiro, apresentaram galhas e massas de ovos quando parasitados por $M$. 
javanica e não com $M$. incognita. Esse fato indica tendência a maior adaptação parasitária de $M$. javanica nessas fruteiras do que $M$. incognita, apesar dos baixos níveis de reprodução determinados.

Com relação à pereira, à macieira e ao marmeleiro, os resultados estão de acordo com os obtidos por Tufts \& Day (1934), Pinochet et al. (1990) e Sharma et al. (1992), confirmando a condição de hospedeiros altamente desfavoráveis de tais genótipos aos nematóides incluídos no estudo. A observação de $M$. incognita raça 2 em marmeleiro 'Portugal', em Itaberá, durante o levantamento, revela uma contradição. Certamente, há reações distintas entre Chaenomeles japonica (marmeleiro do Japão) e Cydonia oblonga 'Portugal' ou comportamento diferenciado do nematóide (raças caracterizadas pela reação nesses hospedeiros).

Já os resultados obtidos com as cultivares de goiabeira foram conflitantes com os encontrados na literatura, em particular a observação de Moura \& Moura (1989). Estes autores relataram que pomar de goiabeira (cultivar não citada), instalado em área de antigo canavial recém-erradicado no interior do Estado de Pernambuco, foi dizimado em razão de severíssimo ataque por nematóide de galhas identificado como $M$. incognita raça 2, observando-se curiosa sintomatologia caracterizada tanto pela ocorrência de galhas típicas como por intensa necrose radicular, resultante de decomposição do córtex; das galhas formadas, obtiveram-se todos os estádios de desenvolvimento, indicando reprodução do parasito. No presente trabalho, pouquíssimos exemplares de $M$. javanica foram extraídos das raízes das três cultivares avaliadas e, no caso de $M$. incognita, só de 'Kumagai', não se observaram galhas aos 120 dias da inoculação. E os bio-ensaios realizados, envolvendo transplantio de estacas enraizadas das três cultivares em solo altamente infestado com ambas as espécies, confirmaram os resultados anteriores. A discrepância pode estar associada às cultivares incluídas nos diferentes estudos ou, mais possivelmente, ao fato de se tratarem de espécies distintas de Meloidogyne envolvidas nos dois casos. Nesse sentido, afigura-se bem possível que a população do relato de Pernambuco seja a mesma que tem causado apreciáveis perdas recentemente em pomares paulistas e fluminenses e que foi considerada diferente de M. incognita, constituindo, ao que tudo indica, uma nova espécie (Ferreira Filho et al., 2000). 
Com relação à reação de resistência da oliveira 'Arbequina' aos dois nematóides ora verificada, também houve discordância em relação aos poucos dados disponíveis na literatura (Diab \& El-Eraki, 1968; Lamberti \& Baines, 1969). Nesse caso, a discrepância está associada, ao que tudo indica, ao emprego de diferentes cultivares nos diversos estudos, pois, conforme a cultivar considerada, ocorreram claras diferenças nos resultados dos trabalhos em relação à formação ou não de galhas e ao tamanho e localização delas nos sistemas radiculares, bem como à intensidade da redução no crescimento das plantas inoculadas.

A presença de reduzidos números de galhas e nematóides nas raízes da framboeseira e da amoreira-preta demonstrou que nenhuma das duas espécies conseguiu parasitar as cultivares estudadas. Os resultados concordam com dados anteriores de que a framboeseira não é boa hospedeira de Meloidogyne, à exceção de M. hapla (McElroy, 1991; Trudgill, 1991; Esnard \& Zuckerman, 1998). É possível que as galhas encontradas nessa fruteira por Carvalho (1951) e também as citadas por Steinberg (1989) fossem devidas a $M$. hapla. Avaliações futuras em outras cultivares poderão confirmar isso.

Algumas fruteiras foram testadas pela primeira vez, como amoreira-preta, framboeseira, nogueira-macadâmia, nespereira e umezeiro. Este último genótipo foi apontado como possuidor de altos níveis de resistência a Meloidogyne spp. (Sherman \& Lyrene, 1983), o que foi corroborado pelos resultados ora obtidos.

\subsection{Capacidade reprodutiva de Meloidogyne em caquizeiros}

Analisando os resultados relativos ao experimento de $M$. incognita raça 2, baseados no esquema de avaliação de Zeck (1971), observa-se, por estimativa, que os genótipos tinham de 25 a $50 \%$ do sistema radicular não funcional e com severos sintomas de galhas. Comparado ao experimento de $M$. javanica, em relação a esse critério ou parâmetro, os genótipos estudados foram mais suscetíveis a $M$. incognita raça 2 do que a $M$. javanica. No experimento de $M$. javanica, os resultados demonstraram que haviam tanto genótipos com o sistema radicular completamente sadio e sem sinais de infestação como genótipos evidenciando grande quantidade de pequenas galhas, mas não 
seriamente afetados quanto ao crescimento. Na Índia, Sethi et al. (1988) verificaram, diferentemente, plantas ainda novas de caquizeiro (sem especificação do genótipo e idade exata das plantas) coletadas em um viveiro de mudas com reduzido crescimento associado a sistemas radiculares altamente parasitados por M. javanica.

Com relação aos outros parâmetros, os resultados mostraram principalmente reduzidas taxas de reprodução dos nematóides durante o período de 120 dias após inoculação, com valores de níveis populacionais bem inferiores aos empregados na própria inoculação. Esse fato sugere que houve infestação inicial pelos juvenis J2, ilustrada pela formação de galhas, mas ocorreu, posteriormente, algum fenômeno que impediu o total desenvolvimento e a subseqüente reprodução do nematóide. $\mathrm{O}$ mais provável é que se tratasse de mecanismo de incompatibilidade, como uma resposta de hipersensibilidade por exemplo, geneticamente controlado pela planta hospedeira e capaz de provocar a má formação das células nutridoras essenciais ao desenvolvimento de Meloidogyne, causando a morte prematura dos nematóides ainda no interior das raízes. No caso de M. incognita, segundo Canto-Saenz (1982), tais genótipos poderiam ser considerados hipersuscetíveis ou intolerantes, isto é, hospedeiros desfavoráveis mas que são significativamente danificados pelo nematóide.

\subsection{Patogenicidade de Meloidogyne incognita ao caquizeiro}

A reação evidenciada pelo caquizeiro 'Kyoto' a Meloidogyne incognita raça 2 foi do tipo "intolerância", conforme descrito por Canto-Saenz (1982). Confirmando indicações do experimento de determinação da capacidade reprodutiva em diferentes genótipos de caquizeiro, ocorreu aqui também intensa formação de galhas no sistema radicular das plantas, comprovando a penetração e infecção pelo parasito. Nos níveis mais altos de inóculo, ou seja, a partir do nível " 800 ", ocorreu redução significativa nos valores de massa seca da parte aérea; ao nível "160", o mais baixo utilizado, observou-se certo efeito estimulante sobre a mesma variável. Entretanto, em todos os níveis de inóculo, a reprodução do nematóide foi muito limitada, se existente. 
Em muitas associações nematóide-planta, baixos níveis populacionais do parasito já são capazes de afetar negativamente o crescimento do sistema radicular e, por conseqüência, da planta como um todo. Por outro lado, é sabido igualmente que muitas vezes a exposição da planta jovem a baixas densidades populacionais pode resultar, como resposta, em estímulo à emissão de novas radicelas e outras formas de expressão de reação ao parasitismo. Entre os muitos relatos experimentais em que tal já foi verificado, pode-se mencionar as associações entre Paratrichodorus minor e cana-deaçúcar, Mesocriconema curvatum e ervilhaca-pilosa, Paratylenchus projectus e ervacorneira, Heterodera schachtii e beterraba açucareira, Meloidogyne sp. e amendoim, crotalária e pimenta, como sumariado por Wallace (1973). No caso de P. minor em cana, por exemplo, a massa da parte aérea foi maior ao nível de 100 espécimes por planta que na testemunha não inoculada e nos níveis 500 ou 1000 (Apt \& Koike, 1962). Esse fenômeno de estímulo ao crescimento do hospedeiro infectado pelo nematóide, quando presente em baixa densidade populacional, verificado tanto com espécies parasitas de órgãos subterrâneos como aéreos da planta, pode inclusive ser considerado comum (Wallace, 1973). No caso de nematóides de galhas, Meloidogyne spp., já se especulou que o estímulo decorrente do parasitismo por baixo número de juvenis infestantes, capaz de aumentar significativamente as massas do sistema radicular e da própria planta, estaria ligado ao fato de o periciclo, sob essas condições, passar a assumir atividade meristemática e causar a produção de excessiva quantidade de radicelas bem próximo ao ápice radicular (Madamba et al., 1965). Segundo Seinhorst (1968), a explicação mais plausível para o estímulo ao crescimento de plantas por nematóides é a de que existem dois efeitos sobre plantas mutuamente independentes, ambos dependentes do nível populacional do nematóide. Tais efeitos, estímulo ao crescimento ('growth stimulation') e redução do crescimento ('growth reduction'), podem ser determinados por equações matemáticas baseadas na variável "nível populacional" e, ao que tudo indica, ocorrem simultaneamente. Assim, na hipótese de valores crescentes de densidade populacional (Pi) de uma certa espécie de nematóide inoculados em determinada planta hospedeira, a produção desta tenderia a crescer inicialmente com o aumento do inóculo, depois ficaria 
constante por um intervalo e, por fim, passaria a decrescer continuamente, após atingido um nível ou patamar considerado limiar de dano.

No presente estudo, o efeito estimulante foi observado somente ao nível "160”, de tal modo que, quando desconsiderado, a regressão mostrou, a partir de "800", linearidade no efeito depressivo do parasitismo sobre a variável massa seca das plantas. Embora as plantas não tivessem multiplicado bem o nematóide e houvessem sobrevivido mesmo a níveis muito elevados de inóculo (como 100000 ovos/ planta), ficou evidente que a exposição ao parasitismo por $M$. incognita raça 2 pode implicar em ocorrência de danos. Em função desses resultados e observações, pode-se antever duas situações de campo tidas como preocupantes em relação à meloidoginose do caquizeiro devida a $M$. incognita: a) utilização para plantio de mudas formadas em solo altamente infestado, do que poderá resultar reduzido crescimento inicial e menor tolerância a estresses edafoclimáticos sob condições de pomar; e b) emprego de mudas sadias ou pouco infestadas, plantadas em área já infestada na qual ocorram plantas daninhas que sejam boas hospedeiras do nematóide; nessas condições, poderá haver constante migração de muitos juvenis formados a partir das invasoras para as raízes do caquizeiro, provocando efeitos semelhantes ou muito próximos aos observados no estudo de patogenicidade ora realizado.

\subsection{Considerações Finais}

Diante dos resultados obtidos e da análise da bibliografia pertinente disponível, ressaltaram, dentro do assunto, algumas lacunas a serem preenchidas e alguns aspectos a serem melhor elucidados pela pesquisa científica no futuro:

a) Certos genótipos de pessegueiro, como 'Okinawa' e 'Nemaguard', há décadas vêm sendo largamente utilizados como porta-enxertos em todo o mundo devido às suas características de resistência a nematóides de galhas, Meloidogyne spp. No entanto, Menten et al. (1977) já mencionaram ocorrência de severa infestação de 'Okinawa' e 'Nemaguard' por espécie não identificada de Meloidogyne nos Estados Unidos. Recentes pesquisas, também nos Estados Unidos, têm permitido a caracterização de biótipos, em 
particular um designado como "biótipo da Flórida", encontrados parasitando pomares de pessegueiros formados sobre porta-enxertos considerados resistentes a Meloidogyne. Seria conveniente, em vista disso, elucidar o relato de Maximiniano (1999) em Minas Gerais, em que se observou parasitismo de 'Okinawa' por Meloidogyne incognita, procurando caracterizar adequadamente as populações do nematóide encontradas associadas, já que no presente estudo não se verificou tal associação em campo ou em casa de vegetação, mediante inoculação artificial de plantas.

b) Necessidade de estudos sobre a relação parasito-hospedeiro entre Rotylenchulus reniformis e marmeleiros, pessegueiros e pereiras, de modo a esclarecer se essas fruteiras são realmente boas hospedeiras do nematóide. Da mesma maneira, há necessidade de se aferir o potencial de dano de Tylenchulus semipenetrans em caquizeiro, pereira e, possivelmente, pessegueiro.

c) Necessidade de melhor compreensão a respeito dos mecanismos de resistência de Rosaceae a nematóides. Há muitos estudos sobre plantas do gênero Prunus, no geral um bom hospedeiro de espécies de Meloidogyne e Pratylenchus. Contudo, para outras fruteiras, como macieira e framboeseira, muito pouco se sabe. Pode-se tratar de mecanismo de "resistência de planta não hospedeira", em que todos os genótipos expressam tal característica, contrastando com a "resistência de planta hospedeira", observada apenas em alguns genótipos (Heath, 2000). Tais estudos deveriam envolver inclusive observações histopatológicas, para a melhor caracterização do fenômeno. A inclusão de diferentes cultivares de goiabeira e distintas populações de Meloidogyne afigura-se essencial nesse caso, no sentido de possibilitar o entendimento do contraste entre os resultados aqui obtidos com os da literatura, tanto nacional como estrangeira, principalmente venezuelana.

d) A bio-ecologia de fitonematóides tem sido largamente estudada, com resultados muito interessantes. Sugere-se, especialmente, a realização de pesquisas sobre as múltiplas interações tróficas que devem ocorrer entre as espécies de nematóides e entre os nematóides e as fruteiras subtropicais e temperadas que lhes servem de hospedeiros, pois essas plantas são perenes e, permanecendo muitos anos num mesmo local, podem 
concorrer ao desenvolvimento de comunidades nematológicas de composição bastante específica. 


\section{CONCLUSÕES}

Fundamentando-se nos resultados obtidos conclui-se que:

a) Fruteiras subtropicais e temperadas constituem hospedeiros de diferentes gêneros e espécies de fitonematóides, mais comumente de formas ecto e semi-endoparasitas que de endoparasitas típicas;

b) Os genótipos de diferentes fruteiras subtropicais e temperadas, comumente utilizados como porta-enxertos, mostram predominantemente reação de resistência frente a Meloidogyne incognita e M. javanica;

c) Os genótipos de caquizeiro, em particular, mostram predominantemente reação de intolerância a Meloidogyne incognita e resistência a M. javanica e,

d) Meloidogyne incognita raça 2 é patogênica ao caquizeiro 'Kyoto', afetando negativamente a altura e a massa seca de raízes. 


\section{REFERÊNCIAS BIBLIOGRÁFICAS}

ABAWI, G.S.; MAI, W.F. Plant parasitic nematodes. In: JONES, A.L.; ALDWINCKLE, H.S. (Ed.) Compendium of apple and pear diseases. St. Paul: APS Press, 1990. p.70-74.

APT, W.J.; KOIKE, H. Influence of the stubby-root nematode on growth of sugarcane in Hawaii. Phytopathology, v.52, p.963, 1962.

BARbOSA, W.; DALL'ORTO, F.A.C.; OJIMA, M.; MARTINS, F.P. Produção e manejo de sementes do pessegueiro porta-enxerto Okinawa. O Agronômico, v.45, n.2/3, p.10-16, 1993.

BARBOSA, W.; DALL'ORTO, F.A.C.; OJIMA, M.; MARTINS, F.P.; RIGITANO, O. Quebra de dormência das sementes do porta-enxerto de pêssego 'Okinawa'. O Agronômico, v.39, n.1, p.41-44, 1987.

BARBOSA, W.; DALL'ORTO, F.A.C.; OJIMA, M.; NOVO, M.C.S.S.; BETTI, J.A.; MARTINS, F.P. Conservação e germinação de sementes e desenvolvimento de plântulas da pereira porta-enxerto Taiwan Nashi-C. Scientia Agricola, v.54, n.3, p.147-151, 1997. 
BARBOSA, W.; OJIMA, M.; DALL'ORTO, F.A.C.; RIGITANO, O.; MARTINS, F.P.; SANTOS, R.R. dos; CASTRO, J.L. de. Melhoramento do pessegueiro para regiões de clima subtropical-temperado: realizações do Instituto Agronômico no período de 1950 a 1990. Campinas: Instituto Agronômico, 1997. 22p. (Documentos IAC, 52).

BARKER, K.R.; CLAYTON, C.N. Relative host suitability of peach cultivars to six species of lesion nematodes. Phytopathology, v.59, p.1017, 1969.

BARKER, K.R.; CLAYTON, C.N. Nematodes attacking cultivars of peach in North Carolina. Journal of Nematology, v.5, n.4, p.265-271, 1973.

BECKER, W.F. Levantamento preliminar de nematóides em pomares de macieira. In: CONGRESSO BRASILEIRO DE NEMATOLOGIA, 15., Botucatu, 1991. Resumos. Nematologia Brasileira, v.15, n.2, p.206-207, 1991.

BELAIR, G.; KHANIZADEH, S. Distribution of plant-parasitic nematodes in strawberry and raspberry fields in Quebec. Phytoprotection, v.75, n.2, p.101-107, 1994.

BIRD, G.W.; MELAKEBERHAN, H. Diseases caused by plant-parasitic nematodes. In: OGAWA, J.M.; ZEHR, E.I.; BIRD, G.W.; RITCHIE, D.F; URIU, K.; UYEMOTO, J.K. (Ed.) Compendium of stone fruit diseases. St. Paul: American Phytopathological Society, 1995. p.61-64.

BITTENCOURT, C.; HUANG, C.S. Brazilian Peltamigratus Sher, 1964 (Nematoda: Hoplolaimidae), with descriptions of six new species. Revue de Nématologie, v.9, n.1, p.3-24, 1986. 
BONETI, J.I.S.; FERRAZ, S. Modificação do método de Hussey \& Barker para extração de ovos de Meloidogyne exigua de raízes de cafeeiro. Fitopatologia Brasileira, v.6, n.3, p.553, 1981.

BROWN, D.J.F.; DALMASSO, A.; TRUDGILL, D.L. Nematode pests of soft fruits and vines. In: EVANS, K.; TRUDGILL, D.J.; WEBSTER, J.M. (Ed.) Plant parasitic nematodes in temperate agriculture. Wallingford: CAB International, 1993. p.427462.

BUHRER, E.M.; COOPER, C.; STEINER, G. A list of plants attacked by the root knot nematode. Plant Disease Reporter, v.17, n.7, p.64-96, 1933.

BURDETT, J.F.; BIRD, A.F.; FISHER, J.M. The growth of Meloidogyne in Prunus persica. Nematologica, v.9, p.542-546, 1963.

CAFÉ FILHO, A.C.; HUANG, C.S. Nematóides do gênero Pratylenchus no Brasil. Fitopatologia Brasileira, v.13, n.3, p.232-235, 1988.

CAFÉ FILHO, A.C.; HUANG, C.S. Description of Pratylenchus pseudofallax n.sp. with a key to species of the genus Pratylenchus Filipjev, 1936 (Nematoda: Pratylenchidae). Revue de Nématologie, v.12, n.1, p.7-15, 1989.

CAMPOS, V.P.; LIMA, R.D.; ALMEIDA, V.F. Nematóides parasitos de grandes culturas identificados em localidades de Minas Gerais e São Paulo. Nematologia Brasileira, v.11, p.226-232, 1987.

CANTO-SAENZ, M. The nature of resistance to Meloidogyne incognita (Kofoid \& White, 1919) Chitwood, 1949. In: RESEARCH \& PLANNING CONFERENCE ON ROOT-KNOT NEMATODES, Meloidogyne spp., 3., Lima, 1982. Proceedings. Raleigh: North Carolina State University, 1983. p.160-165. 
CARES, J.H.; HUANG, S.P. Nematode fauna in natural and cultivated cerrados of central Brazil. Fitopatologia Brasileira, v.16, n.3, p.199-209, 1991.

CARNEIRO, R.M.D.G.; FORTES, J.F.; ALMEIDA, M.R.A. Associação de Criconemella xenoplax com a morte do pessegueiro no Rio Grande do Sul. Nematologia Brasileira, v.17, n.2, p.122-131, 1993.

CARNEIRO, R.M.D.G.; CAMPOS, A.D.; PEREIRA, J.F.M.; RASEIRA, M.C.B. Avaliação de porta-enxertos de Prunus quanto à suscetibilidade ao nematóide anelado e ao conteúdo de enzimas fenol oxidases. Nematologia Brasileira, v.22, n.1, p.30$38,1998$.

CARVAlHO, J.C. Nematóides das raízes encontrados em São Paulo. Arquivos do Instituto Biologico, v.20, p.165-172, 1951.

CASASSA, A.N.; CROZZOLI, R.; MATHEUS, J.; BRAVO, V.; MARÍN, M. Efecto del nematodo agallador Meloidogyne incognita sobre el crecimiento del guayabo (Psidium spp.) em el Estado Zulia, Venezuela. In: ANNUAL MEETING, 30., Mendonza, 1998. Nematropica, v.28, n.2, p.122, 1998.

COHN, E.; DUNCAN, L.W. Nematode parasites of subtropical and tropical fruit trees. In: LUC, M.; SIKORA, R.A.; BRIDGE, J. (Ed.). Plant parasitic nematodes in subtropical and tropical agriculture. Wallingford: CAB International, 1990. p.347-362.

COHN, E.; MINZ, G. Citrus nematode on american persimmon in Israel. Plant Disease Reporter, v.45, n.3, p.505, 1961. 
COOLEN, W.A.; D'HERDE, C.J. A method for the quantitative extraction of nematodes from plant tissue. Ghent: State Agriculture Research Center, 1972. 77p.

COSTA MANSO, E. Studies on the subfamily Hemicycliophorinae (Nematoda: Criconematoidea). Fitopatologia Brasileira, v.21, n.2, p.197-218, 1996.

COSTA MANSO, E.; TENENTE, R.C.V.; FERRAZ, L.C.C.B. Catálogo de nematóides fitoparasitos encontrados associados a diferentes tipos de plantas no Brasil. Brasília: Embrapa, CENARGEN, 1994. 488p.

CROZZOLI, R.; CASASSA, A. Especies y razas de Meloidogyne en el cultivo del guayabo en Venezuela. Revista Faculdade Agronomia, Zulia, v.15, p.107-108, 1998.

CROZZOLI, R.; CASASSA, A.M.; RIVAS, D.; MATHEUS, J. Nemátodos fitoparásitos asociados al cultivo del guayabo en el Estado de Zulia, Venezuela. Fitopatología Venezolana, v.4, n.1, p.2-6, 1992.

CUADRA, R.; QUINCOSA, A. Comportamiento de diferentes especies de Psidium como patrones para guayabos resistentes a Meloidogyne (Nematoda: Heteroderidae). Ciencias de la Agricultura, v.13, p.19-26, 1982.

DALL'ORTO, F.A.C. Marmeleiro (Cydonia oblonga Mill.): propagação seminífera, citogenética e radiosensibilidade - bases ao melhoramento genético e à obtenção de porta-enxertos. Piracicaba, 1982. 161p. Dissertação (Mestrado) - Escola Superior de Agricultura "Luiz de Queiroz”, Universidade de São Paulo.

DALL'ORTO, F.A.C.; OJIMA, M.; BARBOSA, W.; MARTINS, F.P. O nanismo do pessegueiro induzido pela enxertia no damasqueiro-japonês. Pesquisa Agropecuária Brasileira, v.27, n.3, p.517-521, 1992. 
DALL'ORTO, F.A.C.; OJIMA, M.; BARBOSA, W.; SANTOS, R.R. dos; MARTINS, F.P.; SABINO, J.C. Nespereiras enxertadas em marmeleiro: nova opção de produção frutífera sob elevado adensamento de plantio. O Agronômico, v.42, n.1, p.17-27, 1990.

DALL'ORTO, F.A.C.; OJIMA, M.; BARBOSA, W.; RIGITANO, O.; MARTINS, F.P.; CASTRO, J.L. de; SANTOS, R.R. dos; SABINO, J.C. Variedades de pêra para o Estado de São Paulo. Campinas: Instituto Agronômico, 1996. 34p. (IAC. Boletim Técnico, 164).

DIAB, K.A.; EL-ERAKI, S. Plant parasitic nematodes associated with olive decline in the United Arab Republic. Plant Disease Reporter, v.52, n.2, p.150-154, 1968.

DIAZ-SILVEIRA, M.F. El Psidium friedrichsthalianum como patron para guayabo, resistente a los nematodos del genero Meloidogyne. Revista de Agricultura, Habana, v.3, p.80-85, 1975.

DI MAIO, F. Il nematode Tylenchulus semipenetrans Cobb, su radici di loto. Informatore Fitopatologico, v.29, n.9, p.13-14, 1979.

DULLAHIDE, S.R; STIRLING, G.R.; NIKULIN, A.; STIRLING, A.M. The role of nematodes, fungi, bacteria, and abiotic factors in the etiology of apple replant problems in the Granite Belt of Queesland. Australian Journal of Experimental Agriculture, v.34, n.8, p.1177-1182, 1994.

ELLIS, M.A.; CONVERSE, R.H.; WILliAMS, R.N.; WILLIAMSON, B. Compendium of raspberry and blackberry diseases and insects. St. Paul: APS Press, 1991. 100p. 
ESMENJAUD, D.; MINOT, J.C.; VOISIN, R.; PINOCHET, J.; SIMARD, M.H.; SALESSES, G. Differential response to root-knot nematodes in Prunus species and correlative genetic implications. Journal of Nematology, v.29, n.3, p.370-380, 1997.

ESMENJAUD, D.; MINOT, J.C.; VOISIN, R.; SALESSES, G.; SIMARD, M.H. PINOCHET, J. La résistance aux nématodes. L'Arboriculture Fruitière, n.471, p.17-21, 1994.

ESNARD, J.; ZUCKERMAN, B.M. Small fruits. In: BARKER, K.R., PEDERSON, G., WINDHAM, G.R. (Ed.) Plant nematode interactions. Madison: American Society of Agronomy, 1998. p.685-725.

FACHINELLO, J.C.; NACHTIGAL, J.C.; KERSTEN, E. Fruticultura: fundamentos e práticas. Pelotas: Ed. UFPEL, 1996. 311p.

FACHINELLO, J.C.; SILVEIRA, C.A.P.; SPERANDIO, C.; RODRIGUES, A.C.; STRELOW, E.Z. Resistência de porta-enxertos para pessegueiro e ameixeira aos nematóides causadores de galhas (Meloidogyne spp.). Ciência Rural, v.30, n.1, p.69$72,2000$.

FELIPE, A.J.; GÓMEZ-APARISI, J. The almond x peach hybrid rootstocks breeding program at Zaragoza (Spain). Acta Horticulturae, n.451, p.259-262, 1997.

FERNÁNDEZ, C.; PINOCHET, J.; ESMENJAUD, D., SALESSES, G.; FELIPE, A. Resistance among new Prunus rootstocks and selections to root-knot nematodes in Spain and France. Hortscience, v.29, n.9, p.1064-1067, 1994. 
FERRAZ, L.C.C.B. Observations on some Xiphinema species found in Brazil. Nematologia Mediterranea, v.8, n.2, p.141-150, 1980.

FERRAZ, S. Reconhecimento das espécies de fitonematóides presentes nos solos do Estado de Minas Gerais. Experientiae, v.26, n.11, p.255-328, 1980.

FERREIRA FILHO, N.C.; SANTOS, J.M. dos; SILVEIRA, S.F. Caracterização morfológica e bioquímica de uma nova espécie de Meloidogyne parasita da goiabeira no Brasil. In: CONGRESSO BRASILEIRO DE NEMATOLOGIA, 22., Uberlândia, 2000. Anais. Uberlândia: Sociedade Brasileira de Nematologia, 2000. p.135.

FERRIS, J.M.; FERRIS, V.R. Biology of plant-parasitic nematodes. In: BARKER, K.R., PEDERSON, G., WINDHAM, G.R. (Ed.) Plant nematode interactions. Madison: American Society of Agronomy, 1998. p.21-35.

GERMANI, G.; BALDWIN, J.G.; BELL, A.H.; WU, X.Y. Revision of the genus Scutellonema Andrássy, 1958 (Nematoda: Tylenchida). Revue de Nématologie, v.8, n.4, p.289-320, 1985.

GOMES, C.B. Problemas causados por nematóides em fruteiras de clima temperado. In: CONGRESSO BRASILEIRO DE NEMATOlOGIA, 23., Marília, 2001. Anais. Garça: Sociedade Brasileira de Nematologia, 2001. p.45-51.

GOMES, C.B.; CAMPOS, A.D.; ALMEIDA, M.R.A. Ocorrência de Mesocriconema xenoplax e Meloidogyne javanica associados à morte precoce de ameixeiras e à redução da atividade das enzimas fenol oxidase. In: CONGRESSO BRASILEIRO DE NEMATOLOGIA, 22., Uberlândia, 2000. Anais. Uberlândia: Sociedade Brasileira de Nematologia, 2000. p.133. 
GONÇALVES, R.D. O marmeleiro. São Paulo: Secretaria da Agricultura do Estado de São Paulo, 1954. 24p.

GONZÁLEZ, H. El kaki, um nuevo huesped de Tylenchulus semipenetrans em Chile. Agricultura Técnica, v.48, p.56-57, 1988.

GONZALEZ, G.; SOURD, F. Ensayo de tres especies de Psidium y su tolerancia a los nematodos. Ciencia y Tecnica en la Agricultura, Citricos y otros frutales. v.5, n.2, p13-25, 1982.

GONZALVEZ, E.F. Los nematodos del genero Meloidogyne Goeldi en el cultivo de la guayaba y su control. Ciudad de la Haban: Instituto de Investigaciones de Sanidad Vegetal, 1989. 31p.

GOODEY, J.B.; FRANKLIN, M.T.; HOOPER, D.J. The nematode parasites of plants catalogued under their hosts. Farnham Royal: CAB, 1965. 214p.

GRIFFIN, J.D.; ANDERSON, J.L.; JORGENSON, E.C. Interaction of Meloidogyne hapla and Agrobacterium tumefaciens in relation to raspberry cultivars. Plant Disease Reporter, v.52, n.5, p.492-493, 1968.

HANSEN, C.J.; LOWNSBERY, B.F.; HESSE, C.O. Nematode resistance in peaches. California Agriculture, v.10, n.9, p.5, 11, 1956.

HARTMAN, K.M.; SASSER, J.N. Identification of Meloidogyne species on the basis of differential host test and perineal-pattern morphology. In: BARKER, K.R.; CARTER, C. C.; SASSER, J.N. (Ed.) An advanced treatise on Meloidogyne: methodology. Raleigh: NCSU Graphics, 1985. $111 \mathrm{p}$. 
HASHIM, Z. Distribution, pathogenicity and control of nematodes associated with olive. Revue de Nématologie., v.5, n.1, p.169-181, 1982.

HEATH, M.C. Nonhost resistance and nonspecific plant defenses. Current Opinion in Plant Biology, v.3, p.315-319, 2000.

HUANG, S.P.; FREIRE, H.C.A.; CARES, J.H. Grupos composicionais e tróficos dos nematóides associados à sucupira-branca (Pterodon pubescens) em cerrado nativo. Fitopatologia Brasileira, v.21, n.2, p. 156-160, 1996.

HUSSEY, R.S.; BARKER, K.R. A comparison of methods of collecting inocula of Meloidogyne spp., including a new technique. Plant Disease Reporter, v.57, n.12, p.1025-1028, 1973.

INOMOTO, M.M.; MONTEIRO, A.R.; FERRAZ, L.C.C.B. Ocorrência de Tylenchulus semipenetrans e Meloidogyne incognita em caquizeiro no Brasil. Nematologia Brasileira, v.15, n.1, p.82- 84, 1991.

INSERRA, R.N.; VOVLAS, N. The biology of Rotylenchulus macrodoratus. Journal of Nematology, v.12, n.2, p.97-102, 1980.

INSERRA, R.N.; VOVLAS, N.; O’BANNON, J.H.; ESSER, R.P. Tylenchulus graminis n. sp. and T. palustris n. sp. (Tylenchulidae), from native flora of Florida, with notes on T. semipenetrans and T. furcus. Journal of Nematology, v.20, n.2, p.266-287, 1988.

ITOH, Y.; OHSHIMA, Y.; ICHINOHE, M. A root-knot nematode, Meloidogyne mali n.sp. on apple-tree from Japan (Tylenchida: Heteroderidae). Applied Entomology \& Zoology, v.4, n.4, p.194-202, 1969. 
JENKINS, W.R. A rapid centrifugal-flotation technique for separating nematodes from soil. Plant Disease Reporter, v. 48, n.6, p.629, 1964.

KHAN, F.A. Root-knot infection in fruit trees of Zaria and environs. International Nematology Network Newsletter, v.2, n.2, p.6-8, 1985.

KHAN, M.L.; SHARMA, G.C. Effect of temperature and moisture on population fluctuation of nematodes in an apple orchard. Indian Journal of Nematology, v.20, n.1, p.1-13, 1990.

KOCHBA, J.; SPIEGEL-ROY, P. Resistance to root-knot nematode in bitter almond progenies and almond x Okinawa peach hybrids. HortScience, v.7, p.503-505, 1972.

KODIRA, U.C.; WESTERDAHL, B.B. UC IPM Pest management guidelines: apples. Davis: University of California, Division of Agriculture and Natural Resources, 1996. $48 \mathrm{p}$.

KWEE, L.T.; CHONG, K.K. Guava in Malaysia. Kuala Lumpur: Tropical Press, 1990. 280 p.

LAMBERTI, F.; BAINES, R.C. Pathogenicity of four species of Meloidogyne on three varieties of olive trees. Journal of Nematology, v.1, n.2, p.111-115, 1969.

LEDBETTER, C.A. Protecting orchards against nematodes. Agricultural Research, n.7, p.31, 1992 . 
LOOF, P.A.A.; LUC, M. A revised polytomous key for the identification of species of the genus Xiphinema Cobb, 1913 (Nematoda: Longidoridae) with exclusion of the $X$. americanum group. Systematic Parasitology, v.16, p.35-66, 1990.

LOOF, P.A.A.; MAAS, P.W.T. The genus Xiphinema (Dorylaimida) in Surinam. Nematologica, v.18, n.1, p.92-119, 1972.

LORDELLO, L.G.E. Nematóide nocivo ao pessegueiro. Revista de Agricultura, v.48, n.2/3, p.128, 1973.

LORDELLO, L.G.E.; COSTA, C.P da A new nematode parasite of coffee roots in Brazil. Revista Brasileira de Biologia, v.21, n.4, p.363-366, 1961.

LORDELLO, L.G.E.; MARINI, P.R. Alguns nematóides parasitas de plantas do Rio Grande do Sul. Revista de Agricultura, v.49, n.1, p.15-18, 1974.

LORDELLO, L.G.E.; MELO, L.M. de. Breve notícia sobre a ocorrência de nematódeos atacando macieira no Estado de São Paulo. Revista de Agricultura, v.33, n.4, p.223$224,1958$.

LORDELLO, L.G.E.; ZAMITH, A.P.L. Incidência de nematóides em algumas culturas de importância econômica. Divulgação Agronômica Shell, n.2, p.27-33, 1960a.

LORDELLO, L.G.E.; ZAMITH, A.P.L. Sobre os nematóides que parasitam o pessegueiro. Anais da Escola Superior de Agricultura Luiz de Queiroz, v.17, p.361-364, 1960 b.

LOWNSBERY, B.F. Studies of the nematode, Criconemoides xenoplax, on peach. Plant Disease Reporter, v.43, n.10, p.913-917, 1959. 
LOWNSBERY, B.F.; SERR, E.F.; HANSEN, C.J. Deciduous fruit and nut trees. California Agriculture, v. 13, n.9, p.19-20, 1959.

LU, Z.X.; REIGHARD, G.L.; NYCZEPIR, A.P.; BECKMAN, T.G.; RAMMING, D.W. Inheritance of resistance to root-knot nematodes (Meloidogyne sp.) in Prunus rootstocks. HortScience, v.35, n.7, p.1344-1346, 2000.

LUC, M. Contribution à l'étude du genre Criconemoides Taylor, 1936 (Nematoda: Criconematidae). Cahiers ORSTOM Série Biologie Nématologie, v.11, n.1, p.69$131,1970$.

LUC, M.; HUNT, D.J. Redescription of Xiphinema longicaudatum Luc, 1961 and observations on Xiphinema krugi Lordello, 1955 (Nematoda: Longidoridae). Nematologica, v.24, n.1, p.1-18, 1978.

LUNA, A.N.F. Patogenicidade de Helicotylenchus dihystera em Theobroma cacao L var. Catongo. Piracicaba, 1976. 38p. Dissertação (Mestrado) - Escola Superior de Agricultura "Luiz de Queiroz", Universidade de São Paulo.

MADAMBA, C.P.; SASSER, J.N.; NELSON, L.A. Some characteristics of the effects of Meloidogyne spp. on unsuitable hosts. Raleigh: North Carolina Agricultural Experiment Station, 1965. 32p.

MALO, S.E. Nature of resistance of 'Okinawa' and 'Nemaguard' peach to the root-knot nematode Meloidogyne javanica. Proceedings of the American Society for Horticultural Science, v.90, p.39-46, 1967. 
MARULL, J.; PINOCHET, J. Host suitability of Prunus rootstocks to four Meloidogyne species and Pratylenchus vulnus in Spain. Nematropica, v.21, n.2, p.185-195, 1991.

MARULL, J.; PINOCHET, J.; VERDEJO, S.; SOLER, A. Reaction of Prunus rootstocks to Meloidogyne incognita and $M$. arenaria in Spain. Journal of Nematology, v.23, n.4S, p.564-569, 1991.

MARULL, J.; PINOCHET, J.; FELIPE, A.; CENIS, J.L. Resistance verification in Prunus selections to a mixture of thirteen Meloidogyne isolates and resistance mechanisms of a peach-almond hybrid to M. javanica. Fundamental and Applied Nematology, v.17, n.1, p.85-92, 1994.

MATHEUS, J.; SUAREZ, H.Z.; ROSALES, L.C.; TONG, F.; CASASSA, A.; BRAVO, V.; NAVA, A. Reacción histológica de selecciones de Psidium spp. a Meloidogyne incognita en Venezuela. Nematologia Mediterranea, v.27, p.247-251, 1999.

MAUCH, C.H.; MAUCH, N.; FINARDI, N.L. Reações de pessegueiros e da ameixeira ao nematóide das galhas Meloidogyne incognita. Nematologia Brasileira, v. 15, n. 1, p. 59-67, 1991.

MAXIMINIANO, C.; SILVA, T.G.; SOUZA, C.R. de; FERREIRA, E.A.; PEREIRA, A.F.; PEREIRA, G.E.; REGINA, M.A.; CAMPOS, V.P. Nematóides e Pasteuria associados a frutíferas de clima temperado no sul do Estado de Minas Gerais, Brasil. Nematologia Brasileira, v.23, n.1, p.1-10, 1999.

McELROY, F.D. Nematodes of tree fruits and small fruits. In: WEBSTER, J.M. (Ed.) Economic nematology. London: Academic Press, 1972. p.335-376. 
McELROY, F.D. Nematode parasites. In: ELLIS, M.A.; CONVERSE, R.H.; WILLIAMS, R.N.; WILLIAMSON, B. Compendium of raspberry and blackberry diseases and insects. St. Paul: APS Press, 1991. p.59-62.

McSORLEY, R. Nematological problems in tropical and subtropical fruit tree crops. Nematropica, v.22, n.1, p.103-116, 1992.

McSORLEY, R.; CAMPBELL, C.W.; PARRADO, J.L. Nematodes associated with tropical and subtropical fruit trees in south Florida. Proceedings of the Florida State for Horticultural Society, v.95, p.132-135, 1982.

MENDONÇA, M.M. de Estudos sobre Hoplolaiminae encontrados no Brasil (Nemata: Tylenchoidea). Piracicaba, 1976. 90p. Dissertação (Mestrado) - Escola Superior de Agricultura “Luiz de Queiroz”, Universidade de São Paulo.

MENTEN, J.O.; LORDELlO, L.G.; CAMPO DALL'ORTO, F.A.; OJIMA, M.; RIGITANO, O. Resistência do pessegueiro (Prunus persica Batsch) aos nematóides M. incognita e M. arenaria. In: REUNIÃO DE NEMATOLOGIA, 2., Piracicaba, 1977. Trabalhos apresentados. Publicação Sociedade Brasileira de Nematologia, n.2, p.165-174, 1977.

MEYER, A.J. Plant-parasitic nematodes associated with peach orchards in the western cape province. Phytophylactica, v.8, p.21-22, 1976.

MILLER, R.W. Peach tree short life in the United States: update, advances, and future research priorities. In: CONGRESSO BRASILEIRO DE NEMATOLOGIA, 20., Gramado, 1997. Resumos. Gramado: Sociedade Brasileira de Nematologia, 1997. p.25-26. 
MINZ, G.; COHN, E. Susceptibility of peach rootstocks to root-knot nematodes. Plant Disease Reporter, v.46, n.7, p.531-534, 1962.

MONTEIRO, A.R.; LORDELLO, L.G.E. Nematóides parasitos associados à framboesa no Brasil. Revista de Agricultura, Piracicaba, v. 51, n.2, p.122, 1976.

MONTEIRO, A.R.; LORDELLO, L.G.E. Description of Hemicycliophora poranga $\mathrm{n}$. sp. from Brazil (Nemata). Revista Brasileira de Biologia, v.38, n.3, p.569-571, 1978.

MONTEIRO, A.R.; FERRAZ, L.C.C.B.; INOMOTO, M.M.; MORAIS, S.R.A.C. Ocorrência de Criconemella xenoplax associada a pessegueiro com declínio no Brasil. In: CONGRESSO BRASILEIRO DE NEMATOLOGIA, 14., Londrina, 1990. Resumos. Nematologia Brasileira, v.14, p.4, 1990.

MONTEIRO, A.R.; FERRAZ, L.C.C.B.; PIVETTA, F.A.; SANHUEZA, R.M.V. Ocorrência de Pratylenchus scribneri em pomares e viveiros de macieira da região de Vacaria, RS. In: CONGRESSO BRASILEIRO DE NEMATOLOGIA, 11., Viçosa, 1987. Resumos. Nematologia Brasileira, v.11, p.30, 1987.

MONTEIRO, A.R.; MARTINELLI, N.M.; FERRAZ, L.C.C.B.; LORDELLO, R.R.A. Nematóides parasitos de plantas na região de Ilha Solteira (S.P.). In: REUNIÃO DE NEMATOLOGIA, 3., Mossoró, 1978. Trabalhos apresentados. Publicação Sociedade Brasileira de Nematologia, n.3, p. 165-174, 1978.

MOREIRA, W.A.; BARBOSA, F.R.; MOURA, A.O. Distribuição populacional de fitonematóides em goiabeira no submédio do vale do São Francisco. In: CONGRESSO BRASILEIRO DE NEMATOLOGIA, 23., Marília, 2001. Anais. Garça: Sociedade Brasileira de Nematologia, 2001. p.110. 
MOURA, R.M.; MOURA, A.M. Meloidoginose da goiabeira: doença de alta severidade no Estado de Pernambuco, Brasil. Nematogia Brasileira, v.13, p.13-19, 1989.

NOGUEIRA, D.J.P. Os porta-enxertos na fruticultura de clima temperado. Informe Agropecuário, v.11, n.125, p.3-12, 1985.

NESBITT, R.B. New host plants of plant parasitic nematodes in California. Plant Disease Reporter, v.40, n.3, p.276, 1956.

NETSCHER, C.; SIKORA, R.A. Nematode parasites of vegetables. In: LUC, M.; SIKORA, R.A.; BRIDGE, J. (Ed.). Plant parasitic nematodes in subtropical and tropical agriculture. Wallingford: CAB International, 1990. p.237-283.

NYCZEPIR, A.P. Nematode management strategies in stone fruits in the United States. Journal of Nematology, v.23, n.3, p.334-341, 1991.

NYCZEPIR, A.P.; BECKER, J.O. Fruit and Citrus trees. In: BARKER, K.R., PEDERSON, G., WINDHAM, G.R. (Ed.) Plant nematode interactions. Madison: American Society of Agronomy, 1998. p.637-684.

NYCZEPIR, A.P.; HALBRENDT, J.M. Nematode pests of deciduous fruit and nut trees. In: EVANS, K.; TRUDGILL, D.J.; WEBSTER, J.M. (Ed.) Plant parasitic nematodes in temperate agriculture. Wallingford: CAB International, 1993. p.381425.

NYCZEPIR, A.P.; BECKMAN, T.G.; REIGHARD, G.L. Reproduction and development of Meloidogyne incognita and M. javanica on Guardian peach rootstock. Journal of Nematology, v.31, n.3, p.334-340, 1999. 
NYCZEPIR, A.P.; ESMENJAUD, D.; EISENBACK, D.J. Pathogenicity of Meloidogyne sp. (FL - isolate) on Prunus in the southeastern United States and France. In: ANNUAL MEETING OF THE SOCIETY OF NEMATOLOGISTS, 37., St. Louis, 1998. Abstracts. Journal of Nematology, v.30, n.4, p.509, 1998.

NYCZEPIR, A.P.; REILLY, C.C.; OKIE, W.R. Effect of initial population density of Criconemella xenoplax on reducing sugars, free amino acids, and survival of peach seedlings over time. Journal of Nematology, v.19, n.3, p. 296-303, 1987.

NYCZEPIR, A.P.; BERTRAND, P.F.; MILLER, R.W.; MOTSINGER, R.E. Incidence of Criconemella spp. and peach orchand histories in short-life and non-short-life sites in Georgia and South Carolina. Plant Disease, v.69, n.10, p.874-877, 1985.

NYCZEPIR, A.P.; ZEHR, E.I.; LEWIS, S.A.; HARSHMAN, D.C. Short life of peach trees induced by Criconemella xenoplax. Plant Disease, v.67, n.5, p.507-508, 1983.

OJIMA, M.; DALL'ORTO, F.A.C.; RIGITANO, O. Germinação de sementes de caqui. Campinas: Instituto Agronômico, 1978. 13p. (IAC. Boletim Técnico, 31).

OJIMA, M.; RIGITANO, O.; SCARANARI, H.J.; MARTINS, F.P.; DALL'ORTO, F.A.C.; NAGAI, V. Variedades e espaçamento da nespereira. Campinas: Instituto Agronômico, 1977. 14p. (IAC. Boletim Técnico, 46).

OJIMA, M.; RIGITANO, O.; DALL'ORTO, F.A.C.; BARBOSA, W.; RIBEIRO, I.J.A.; TERRA, M.M.; AMARO, A.A.; BILLER, V.S.P.; BETTI, J.A.; KUNIYUKI, H.; MARTINS, F.P.; SCARANARI, H.J.; FAHL, J.I. Fruticultura de clima temperado no Estado de São Paulo. Campinas: Instituto Agronômico, 1984. 72p. (IAC. Boletim Técnico, 89). 
ORTON WILLIAMS, K.J. Macrophosthonia xenoplax. St. Albans: CAB, 1972. 2p. (C.I.H. Descriptions of Plant-Parasitic Nematodes, 12).

PENTEADO, S.R. Fruticultura de clima temperado em São Paulo. Campinas: Fundação Cargill, 1986. 173p.

PETIT, P.R. Reconocimiento de nematodos fitoparasitos asociados a frutales de importancia economica em Venezuela. Fitopatología Venezolana, v.3, n.1, p.2-5, 1990.

PHILLIS, I. Resistance of peach seedlings to root-knot nematode attack. International Nematology Network Newsletter, v.6, n.3, p.3-5, 1989.

PHILLIS, J. An up-dated list of plant parasitic nematodes from Cyprus and their economic importance. Nematologia Mediterranea, v.23, p.307-314, 1995.

PINO, F.A. (Coord.) Levantamento censitário de unidades de produção agrícola do Estado de São Paulo. São Paulo: Secretaria de Agricultura e Abastecimento do Estado de São Paulo, Instituto de Economia Agrícola, Coordenadoria de Assistência Técnica Integral, 1997. 4v.

PINOCHET, J. Los nematodos em melocotonero. Fruticultura Profesional, n.46, p.3540, 1992.

PINOCHET, J. La seleccion de patrones de frutales subtropicales y de clima templado frente a nematodos. In: CONGRESSO INTERNACIONAL DE NEMATOLOGIA TROPICAL, Rio Quente, 1995. Programa e anais. Rio Quente: Sociedade Brasileira de Nematologia, Organização dos Nematologistas da América Tropical, 1995. p.331-340. 
PINOCHET, J. Breeding and selection for resistance to root-knot and lesion nematodes in Prunus rootstocks adapted to Mediterranean conditions. Phytoparasitica, v. 25, n.4, p.271-274, 1997.

PINOCHET, J.; VERDEJO, S.; MARULL, J. Evaluation of seven Prunus rootstocks to three species of Meloidogyne in Spain. Nematropica, v.19, n.2, p.125-134, 1989.

PINOCHET, J.; VERDEJO-LUCAS, S.; MARULL, J. Host suitability of eight Prunus spp. and one Pyrus communis rootstocks to Pratylenchus vulnus, P. neglectus, and $P$. thornei. Journal of Nematology, v.23, n.4S, p.570-575, 1991.

PINOCHET, J.; FERNÁNDEZ, C.; ESMENJAUD, D.; DOUCET, M. Effects of six Pratylenchus vulnus isolates on the growth of peach-almond hybrid and apple rootstocks. Journal of Nematology, v.25, n.4S, p.843-848, 1993.

PINOCHET, J.; VERDEJO, S.; SOLER, A.; CANALS, J. Host range of a population of Pratylenchus vulnus in commercial fruit, nut, citrus, and grape rootstocks in Spain. Journal of Nematology, v. 24, n.4S, p.693-698, 1992.

PINOCHET, J.; ANGLÈS,M.; DALMAU, E.; FERNÁNDEZ, C.; FELIPE, A. Prunus rootstock evaluation to root-knot and lesion nematodes in Spain. Journal of Nematology, v.28, n.4S, p.616-623, 1996.

PINOCHET, J.; MARULL, J.; VERDEJO, S.; SOLER, A.; FELIPE, A. Evaluation of rootstocks of plum, damson, pear and quince on the gall nematode, Meloidogyne incognita (Kofoid \& White) Chitwood. Boletin de Sanidad Vegetal - Plagas, v.16, n.4, p.717-722, 1990. 
PINOCHET, J. CALVET, C.; HERNÁNDEZ-DORREGO, A.; BONET, A.; FELIPE, A.; MORENO, M. Resistance of peach and plum rootstocks from Spain, France, and Italy to root-knot nematode Meloidogyne javanica. Hortscience, v.34, n.7, p.1259-1262, 1999.

PRUYNE, P.T.; MERWIN, I.A.; MULLIN, P.G.; GIBSON, D.M. Diagnosis of apple replant problems in New York orchand soils and evaluation of nematode suppressive cover crops. Acta Horticulturae, n.363, p.121-128, 1994.

RASHID, F.; GERAERT, E.; SHARMA, R.D. The genus Peltamigratus Sher, 1964 with description of two new species (Nematoda: Tylenchida). Revue de Nématologie, v.10, n.1, p.3-21, 1987.

RASKI, D.J. On the morphology of Criconemoides Taylor, 1936 with descriptions of six new species (Nematoda: Criconematidae). Proceedings of the Helminthological Society of Washington, v.19, p.85-99, 1952.

RASKI, D.J. Tylenchulidae in agricultural soils. In: NICKLE, R. (Ed.). Manual of agricultural nematology. New York: Marcel Dekker, 1991. p. 761-794.

RASKI, D.J.; SHER, S.A.; JENSEN, F.N. New host records of the citrus nematode in California. Plant Disease Reporter, v.40, n.10, p.1047-1048, 1956.

RIDOLFI, M.; SASANELLI, N.; PATUMI, M.; D'ADDABBO, T.; FONTANAZZA, G.; LAMBERTI, F. Metabolismo fenolico e perossidasico in piante di olivo attacate da nematodi galligeni. Italus Hortus, v.5, n.4, p.22-26, 1998.

RIGITANO, O.; OJIMA, M.; ALVES, S. Pereiras enxertadas sobre marmeleiro. Campinas: Instituto Agronômico, 1975a. 15p. (IAC. Boletim Técnico, 25). 
RIGITANO, O.; OJIMA, M.; CAMPO DALL'ORTO, F.A. Comportamento de novas seleções de pêssegos introduzidos da Flórida. Campinas: Instituto Agronômico, 1975b. 12p. (Circular, 46).

ROMAN, J.; HIRSCHMANN, H. Morphology and morphometrics of six species of Pratylenchus. Journal of Nematology, v.1, n.4, p.363-386, 1969.

SANTAMOUR, F.S.; RIEDEL, L.G.H. Suscetibility of various landscape trees to rootknot nematodes. Journal of Arboriculture, v.19, n.5, p.257-259, 1993.

SAS INSTITUTE. SAS/STAT: user's guide: release 6.03 ed. Cary, 1988. 1028p.

SASANELLI, N.; COIRO, M.I.; D'ADDABBO, T.; LEMOS, R.J.; RIDOLFI, M.; LAMBERTI, F. Reaction of an olive cultivar and an olive rootstock to Xiphinema index. Nematologia Mediterranea, v.27, p. 253-256, 1999.

SCHERB, C.T.; CAMPOS, V.P.; CHALFUN, N.N.J. Resistência de pessegueiro variedades Okinawa e R-15-2 ao nematóide Meloidogyne incognita. In: CONGRESSO BRASILEIRO DE NEMATOLOGIA, 17., Jaboticabal, 1993. Resumos. Nematologia Brasileira, v.17, n.1, p.16, 1993.

SCOTTO LA MASSÈSE, C.; GRASSELY, C.; MINOT, J.C.; VOISIN R. Différence de comportement de 23 clones et hybrides de Prunus à l'égard de quatre espèces de Meloidogyne. Revue de Nématologie, v.7, n.3, p.265-270, 1984. 
SEINHORST, J.W. A model for the relation between nematode density and yield of attacked plants including growth stimulation at low densities. In: SYMPOSIUM INTERNATIONAL DE NEMATOLOGIE, 8., Antibes, 1968. Abstracts. Antibes: Comptes Rendus, 1968. p.83.

SETHI, C.L.; GAUR, H.S.; KAUSHAL, K.K.; SRIVASTAVA, A.N.; KHAN, E. Occurence of root-knot nematode on fruit plants in India and its association with Agrobacterium tumefaciens. International Nematology Network Newsletter, v.5, n.2, p.12-13, 1988.

SHARMA, R.D. Plant parasitic nematodes in the São Francisco Valley, Pernambuco Brazil. Nematropica, v.3, n.2, p.51-54, 1973.

SHARMA, R.D. Nematodes of the cocoa region of Bahia, Brazil. VI. Nematodes associated with tropical fruit trees. In: REUNIÃO DE NEMATOLOGIA, 2., Piracicaba, 1977. Trabalhos apresentados. Publicação Sociedade Brasileira de Nematologia, n.2, p.109-123, 1977.

SHARMA, G.C.; SHARMA, G.; KHAN, M.I. Reaction of crab apple to root knot nematode (Meloidogyne incognita). Indian Journal of Hill Farming, v.5, n.2, p.147, 1992.

SHARPE, R.H.; HESSE, C.O.; LOWNSBERY, B.F. Breeding peaches for root-knot nematode resistance. Journal of the American Society for Horticultural Science, v.94, p.209-212, 1969.

SHER, S.A. Revision of the Hoplolaiminae (Nematoda) IV. Peltamigratus n. gen. Nematologica, v.9, p.455-467, 1964. 
SHER, S.A. Revision of the Hoplolaiminae (Nematoda) VI. Helicotylenchus Steiner, 1945. Nematologica, v.12, p.1-56, 1966.

SHERMAN, W.B.; LYRENE, P.M. Improvement of peach rootstock resistant to rootknot nematodes. Proceedings of the Florida State for Horticultural Society, v.96, p.207-208, 1983.

SHERMAN, W.B.; LYRENE, P.M.; HANSCHE, P.E. Breeding peach rootstocks resistant to root-knot nematodes. Hortscience, v.16, n.4, p.523-524, 1981.

SHERMAN, W.B.; LYRENE, P.M.; SHARPE, R.H. Flordaguard peach rootstock. HortScience, v.26, n.4, p.427-428, 1991.

SIDDIQI, M.R. Rotylenchulus reniformis. St. Albans: CAB, 1972. 2p. (C.I.H. Descriptions of Plant-Parasitic Nematodes, 5).

SINISCALCO, A.; LAMBERTI, F.; INSERRA, R. Reazione di portainnesti del pesco a popolazioni italiane di due specie di nematodi galligeni (Meloidogyne Goeldi). Nematologia Mediterranea, v.4, p.79-84, 1976.

SOUZA, J.T. de; MAXIMINIANO, C.; CAMPOS, V.P. Nematóides associados a plantas frutíferas em alguns estados brasileiros. Ciência e Agrotecnologia, v.23, n.2, p.353-357, 1999.

SPERANDIO, C.A. Identificação de nematóides fitoparasitos do Rio Grande do Sul Brasil. Piracicaba, 1992. 126p. Tese (Doutorado) - Escola Superior de Agricultura “Luiz de Queiroz”, Universidade de São Paulo.

STEINBERG, E. Amora-preta e framboesa. São Paulo: Ed. Nobel, 1989. 64p. 
STOKES, D.E. Parasitism by Pratylenchus brachyurus on three peach rootstocks. Nematologica, v.13, n.1, p.153, 1966.

SWART, A.; HUGO, H.J. Plant parasitic nematodes in pear orchards in the eastern and western Cape. Phytophylactica, v.16, n.1, p.49-52, 1984.

TACCONI, R.; MANCINI, G. Nematodi associati al melo e al pero. L'Informatore Agrario, v.46, n.21, p.79-83, 1990.

TAYLOR, A.L.; SASSER, J.N. Biology, identification and control of root-knot nematodes (Meloidogyne species). Raleigh: North Carolina State University, 1978. $111 \mathrm{p}$.

TORRALLARDONA, S.D. Melocotoneros, nectarinas y pavías: portainjertos y variedades. Barcelona: Fundación "la Caixa”, 1993. 54p.

TOWNSHEND, J.L. Growth of 'Bartlett' pear seedlings in response to number of rootlesion nematodes and temperature. Hortscience, v. 25, n. 3, p.318-320, 1990.

TRUDGILL, D.L. Raspberry re-planting disorders and soil sterilisation. Bulletin of the Scottish Crop Research Institute, v. 2, p.21-30, 1983.

TRUDGILL, D.L. Resistance to and tolerance of plant parasitic nematodes in plants. Annual Review of Phytopathology, v.29, p.167-192, 1991.

TUFTS, W.P.; DAY, L.H. Nematode resistance of certain deciduous fruit tree seedlings. Proceedings of the American Society for Horticultural Science, v. 31, n.1, p.75-82, 1934. 
VOVLAS, N.; FERRAZ, S.; SANTOS, J.M. dos Description of Discocriconemella mineira $\mathrm{n}$. sp. and D. degrissei males from Brazil. Journal of Nematology, v.21, n.3, p.335-341, 1989.

VRAIN, T.C.; DAUBENY, H.A. Relative resistance of red raspberry and related genotypes to root lesion nematode. HortScience, v.21, n.11, p.1435-1437, 1986.

VRAIN, T.C.; DAUBENY, H.A.; HALL, J.W.; DEYOUNG, R.M.; ANDERSON, A.K. Inheritance of resistance to root lesion nematode in red raspberry. HortScience, v.29, n.11, p.1340-1341, 1994.

WALLACE, H.R. Nematode ecology and plant disease. London: Arnold, 1973. 228p.

WEHUNT, E.J. Nematode parasites of peach and other tree crops. In: NICKLE, W.R. (Ed.) Plant and insect nematodes. New York: Marcel Dekker, 1984. p.435-455.

WEINBERGER, J.H.; MARTH, P.C.; SCOTT, D.H. Inheritance study of root knot nematode resistance in certain peach varieties. Proceedings of the American Society for Horticultural Science, v.42, n.4, p.321-325, 1943.

YOUNG, M.J.; SHERMAN, W.B. Evaluation of peach rootstocks for root-knot nematode resistance. Proceedings of the Florida State for Horticultural Society, v.90, n.2, p.241-242, 1977.

ZEM, A.C. Nematóides associados a algumas plantas nativas e cultivadas do cerrado de Itirapina/São Paulo. Revista de Agricultura, Piracicaba, v.52, n.2/3, p.112, 1977. 